\title{
UN MODELO DE ANÁLISIS DEL POBLAMIENTO RURAL EN EL VALLE DEL DUERO (SIGLOS VIII-X) \\ A PARTIR DE UN ESPACIO MACRO-REGIONAL: LAS TIERRAS GALAICO-PORTUGUESAS
}

\author{
JORGE L. QUIROGA \\ E.H.E.H. Casa de Velázquez (Madrid) \\ MÓNICA R. LOVELLE \\ Universidad de Santiago de Compostela
}

\section{SUMARIO}

1. La historia del poblamiento rural durante los siglos VIII y IX. un problema de historia micro-regional en la macro-región del valle del Duero: 1.1. El debate historiográfico. 1.2. Un modelo interpretativo para el espacio del Miño al Duero: la desestructuración del poblamiento antiguo y el desarrollo de un hábitat disperso y marginal.- 2. El proceso de reorganización del poblamiento rural entre el Miño y el Duero desde finales del siglo IX a finales del siglo X: 2.1. La 'aparición' de las villae en los textos y la 'restauración' del poblamiento antiguo. 2.2. La 'reorganización' de la antigua red eclesiástica rural.- Epílogo: De 'desiertos', 'oasis' y 'fantasmas' en la España medieval.

En este trabajo, se trata de ofrecer, a partir del espacio galaicoportugués y, más conconcretamente, entre los ríos Miño y Duero (Fig.1), los

"Anuario de lsstudios Medievales". 27 (1997) 
resultados de nuestra investigación ${ }^{1}$ sobre el poblamiento rural entre la antigüedad tardía y la alta Edad Media²

Abordaremos, en primer lugar, los problemáticos siglos VIII y IX: una breve historiografía, por una parte, y la proposición de un modelo interpretativo, basado en un modelo preciso de análisis, para el espacio entre el Miño y el Duero, por otra. A continuación, en segundo lugar, nos centraremos en el período, menos conflictivo y enigmático, de finales del IX y durante el siglo $\mathrm{X}$ : sintetizando el proceso de aparición de las villae en la documentación correspondiente a nuestro espacio objeto de estudio ${ }^{3}$ y la restauración del poblamiento antiguo, por una parte; y la reorganización de la antigua red eclesiástica rural, por otra.

\section{LA HISTORIA DEL POBLAMIENTO RURAL DURANTE LOS SIGLOS VIII Y IX: \\ UN PROBLEMA DE HISTORIA MICRO-REGIONAL EN LA MACRO-REGIÓN DEL VALLE DEL DUERO}

Con el título de este epígrafe queremos subrayar la orientación que seguiremos y a partir de la cual pensamos hay que abordar el problema de la "despoblación" y de la "repoblación" del valle del Duero, si no queremos caer en el error (si podemos afirmarlo así) geográfico de Sánchez Albornoz. En efecto, éste había considerado el valle del Duero como un espacio situado entre el mar Cantábrico y el Sur del río Duero. Es el valle del Duero

\footnotetext{
'Que sintetizan una parte del capítulo II (Parte III) de la Tesis doctoral de uno de los autores de este estudio (Du Miño au Douro: Histoire et Archéologie du peuplement entrè l'Antiquité tardive et le haut Moyen Âge, $V^{c}-X^{e}$ s., Université de Paris-Sorbonne-Universidad de Santiago de Compostela, Tesis doctoral inédita, París-Santiago de Compostela, 1997).

'En este trabajo nos centramos exclusivamente en los siglos VIII al X. Haremos, no obstante, continuas referencias al período $\mathrm{V}$ a VII e incluso al romano; períodos que no podemos abordar con todo el detalle deseado en el ámbito de este estudio, sin riesgo de sobrepasar ampliamente las dimensiones consideradas normales para un artículo en una revista científica.

${ }^{3}$ Más tardía, como es bien sabido, que en el espacio al Norte del Miño, en razón de la procedencia y carácter de la propia documentación (generada como consecuencia y al servicio del proceso de expansión de la monarquía astur leonesa y de las diferentes entidades monásticas que surgen al calor de ese proceso), recogida para el espacio del Miño al Duero en: A. JEsús Da CosTa, Liber Fidei Sanctae Bracarensis ecclesiae. I, Braga, 1965; "Portugalia Monumenta Historica", Diplomata et Chartae, I, red. 1967; J.M. ANDRADE CERnADAS, O Tombo de Celanova: Estudio introductorio, edición e indices (ss. IX XII), 2 vols. (Fontes documentais para a Historia de Galicia. Consello da Cultura Galega), Santiago de Compostela, 1995.
} 
'historiográfico', como muy bien ha señalado J.A. García de Cortazart'. Pero la delimitación geográfica del valle del Duero, al menos en el noroeste de la Península Ibérica, se situa entre los ríos Miño-Sil y Duero. Por lo tanto, la casi totalidad de la actual comunidad autónoma gallega no forma parte del valle del Duero geográfico ${ }^{5}$. En nuestra opinión (y pensamos que a los ojos de cualquier geógrafo) no es posible incluir en el valle del Duero geográfico ni Galicia, ni Asturias, ni Cantabria, ni el Pais Vasco ${ }^{6}$. En este valle del Duero (nos referimos ahora al territorio entre el Miño y el Duero) es necesario diferenciar también (y eso tampoco lo ha hecho Sánchez Albornoz) los grandes valles y los grandes sistemas montañosos. Los textos, como veremos, nos informan casi siempre de los grandes valles ${ }^{7}$, pero casi nunca de los grandes sistemas montañosos (al menos, no a finales del s. IX y durante el X). La gran extensión del valle del Duero geográfico y las diferencias existentes en el interior del mismo, no permiten abordarlo globalmente, sino a partir del análisis micro-regional ${ }^{8}$. Así, en el marco de este estudio, consideraremos el valle del Duero geográfico como un espacio macro-regional y el territorio entre el Miño y el Duero como un espacio micro-regional en el interior del mismo (Fig. 1). A partir de esta "micro-

${ }^{4}$ J.A. GarCía DE CORTÁzAR, Las formas de organización social del espacio en el valle del Duero en la Alta Edad Media: de la espontaneidad al control feudal, "Despoblación y colonización en el valle del Duero, siglos VIII-XX" (Fundación Sánchez Albornoz. IV Congreso de Estudios Medievales), León. 1995. pp. 13-44.

${ }^{5}$ Esta distinción, con las observaciones y críticas a las tesis albornocianas que ello conlleva, ha sido ya efectuada por el excelente geógrafo portugués O. Ribeiro en su trabajo: O. RIBEIRO, A formação de Portugal, Lisboa, 1987.

"Esta delimitación geográfica es señalada por J.A. García de CORTÁzAR, op.cit.

${ }^{7}$ Lo que no parece ser el caso de algunas de las zonas señaladas por E. Peña Bocos: " ...Los espacios denominados montes aparecen mencionados en todas la areas a partir del siglo IX, a excepción de la Bureba y la zona de Burgos Ubierna, en la que se documentan a partir del siglo X, quizás por la procedencia de los documentos que ilustran dichas areas...". E. PEÑa Bocos. La Atribución Social del Espacio en la Castilla Altomedieval. Una mueva aproximación al Feudalismo Peninsular, Santander, 1995, p. 43.

${ }^{8}$ Este análisis micro-regional ha sido efectuado por nosotros con ocasión de nuestras Tesis doctorales constituyendo el Ir capítulo de la IV a parte (el mundo rural) de ese estudio. Para el espacio entre el Cantábrico y el Miño han sido 5 los espacios micro-regionales analizados (del Tambre al Lérez, el bajo valle del Miño, el territorio de Samos, el territorio de Sobrado y el territorio de Lugo), para el espacio entre el Miño y el Duero hemos centrado nuestro estudio en 4 zonas (del Miño al Câvado, del Câvado al Duero, el alto valle del Támega y del Sabor al Duero). Evidentemente, no podemos presentar aquí los resultados en detalle para cada una de las microregiones. Nos limitaremos a presentar una síntesis, a partir del análisis micro y macroregional, para el territorio entre el Miño y el Duero. 
región" es posible proponer un modelo interpretativo ${ }^{9}$ que, esperamos, pueda aportar algo a la comprensión de la historia del poblamiento rural en la macro-región del valle del Duero.

\subsection{El debate historiográfico}

Cuando se aborda el tema del poblamiento durante los siglos VIII y IX es necesario recordar, aunque sea de forma breve, ciertos trabajos vinculados a esta polémica historiográfica sobre la "despoblación" y la "repoblación" del valle del Duero. Es habitual comenzar con una referencia al historiador portugués Herculano quien, según el propio Sánchez Albornoz, es el autor de la tesis del "desierto estratégico" del valle del Duero ${ }^{10}$. Pero, sin duda, el que ha dado cuerpo a esa tesis con argumentos basados en "centenas y centenas de documentos" es el propio Sánchez Albornoz". Nos parece bastante dificil, leyendo las obras de Sánchez Albornoz, afirmar que "ha basado su teoría sobre la nada"'2. Mas sincero, y ajustado a la realidad, es reconocer que su tesis "molesta" considerablemente a los historiadores que trabajan exclusivamente con los mismos documentos ${ }^{13}$ que el insigne

"De cuya validez y operatividad para otras zonas del valle del Duero, podrán dar fe solamente nuevos estudios micro-regionales a lo largo del valle del Duero. Estudios en los que. por supuesto, la arqueología deberá estar presente. si no se quiere correr el riesgo de obtener una visión sesgada y simplificadora.

"Herculano. História de Portugal. III. pp. $183 \mathrm{ss}$ 1966.

"C. Sánchez Albornoz. Despoblación ye Repoblación del valle del Duero, Buenos Aires.

${ }^{12}$ En (a nuestro parecer) desafortunada frase de J.A. Gutiérrez González: "...apegado obsesivamente a la literalidad de los textos y empeñado en demostrar la herencia goda del reino astur, sobre todo a través de lo institucional, desarrolló su teoría de la despoblación y posterior repoblación sobre la nada con más afán que los propios cronistas oficiales, hasta situar en la escaramuza de Covadonga los orígenes mismos de la Nación Española...", J.A. GuTIÉRREZ GonzÁlez, Fortificaciones y' feudallismo en el origen y formación del reino leonés (siglos IXXIII). Universidad de Valladolid. 1995, p. 101.

${ }^{13}$ Rechazamos la utilización del término "historiadores de formación documentalista", puesto que lo consideramos fruto de una situación actual y de una evolución de la investigación reciente. Hasta hace unos años, y en la Universidad española actual de forma mayoritaria al menos al Norte del Duero, un medievalista sólo podía tener una formación documentalista. No es. por lo tanto, una carencia formativa, sino una situación académica anquilosada y acomodaticia la que impide la formación de medievalistas de "formación arqueológica y documentalista". como lo expresa M. de Boüard: "...Larcheologo medievale deve essere innanzitutto preparato alla ricerca sotorica: per compiere proficuamente lo scavo di un insediamento, di una fortificazione. Ie sue conoscenze nel campo della storia medievale non saranno mai né abbastanza vaste. né abbastanza approfondite: é questa senza dubbio la principale caratteristica del'archeologia medievale ...". M. DE BOÜARD. L'Archeologia 
medievalista ${ }^{14}$; por que, finalmente, hay que reconocer que Sánchez Albornoz ha construido sólidamente su tesis: no sólo ha utilizado las crónicas cristianas $^{15}$, árabes ${ }^{16}$ y "centenas y centenas de documentos" ${ }^{17}$, sino que se ha apoyado además en el análisis de la evolución del poblamiento en el valle del Duero desde época romana ${ }^{18}$. La lectura, "literal", según se suele decir $^{19}$, de todas las fuentes escritas da, sin duda, la razón a Sánchez Albornoz: tanto las crónicas como los documentos nos hablan siempre del fenómeno de la "despoblación" y del estado ruinoso de las iglesias abandonadas como consecuencia de los conocidos acontecimientos de comienzos y, sobre todo, de mediados del siglo VIII ${ }^{20}$.

La visión de "ruptura"21 que Sánchez Albornoz tenía de la evolución del poblamiento en el valle del Duero (ya desde finales de la época romana), no era la única existente a finales del s. XIX y principios del XX. En efecto, tras la publicación de la monumental obra de Herculano, A. Sampaio (entre 1899-1903) publica en el primer número de la Revista Portugalia una serie de artículos sobre la evolución del poblamiento rural en

medievale nelle recenti esperienze francesi, "Quaderni Storici", 24 (1973), p. 746 (pp. 745-766). Recordemos, por otra parte, que hacer Arqueología Medieval no significa forzosamente realizar excavaciones arqueológicas, éstas son siempre la última etapa de un largo proceso que comienza, lógicamente, con el análisis de la documentación escrita existente : "...La fouille ne trouve pas en elle même sa justification: elle est un moyen qui permet de parvenir à une connaissance historique, un moment d'une recherche...", M. DE BOÜARD, Manuel d' Archéologie Médiévale. De la fouille à l' histoire, París, 1975, p. 14.

$14 "$ "...Pero tras la exposición y evaluación de los numerosos indicios que aquí y allí han dejado las fuentes escritas parece que la racionalidad de la explicación de estos fenómenos opera en contra de la tesis de la despoblación que en la actualidad está pasando a convertirse más que una tesis científica en un prejuicio explicativo que entorpece todo intento de renovar la visión de los orígenes de la sociedad leonesa...", J.M. MínGUEZ, Innovación y pervivencia en la colonización del valle del Duero, "Despoblación y colonización del valle del Duero, siglos VIII XX", op.cit, p. 79.

${ }^{15}$ C. SÁNChez Albornoz, Despoblación y Repoblación, op. cit., p. 123-138.

${ }^{16}$ Ibidem.

${ }^{17}$ Ibidem, pp. 13-121.

${ }^{18}$ Ibidem, pp. 138-155.

${ }^{19}$ J.M. Novo Guisán, Los pueblos Vascos-Cantábricos y Galaicos en la Antigüedad tardía (ss. III-IX), Universidad de Alcalá de Henares, 1992, p. 146.

${ }^{20}$ Nos referimos a la 'invasión' árabe del 711 y a las campañas de Alfonso I y de su hermano Fruela a mediados de ese siglo, respectivamente.

${ }^{21}$ Título del capítulo IV de la segunda parte de la obra de Sánchez Albornoz: Ruptura con el ayer. C. SÁNCHEZ Albornoz, Despoblación y Repoblación, op. cit., pp. 188 y ss. 
el Norte de Portugal ${ }^{22}$. Como Sánchez Albornoz, Sampaio traza una historia del poblamiento desde época romana con un método original: la utilización de los documentos medievales para el estudio del poblamiento romano.Del análisis de la documentación, y contra la imagen de las "cintas de desiertos" de Herculano, Sampaio subraya que nunca ha habido tal "despoblación" sino una desorganización profunda y prolongada como consecuencia de la ausencia de un poder, de la situación de "guerra permanente", y de la apropiación por parte de la monarquía astur-leonesa de las tierras conquistadas, produciéndose un cambio de propietarios (por apprissio o pressura ${ }^{23}$. Precisamente, en este momento, en el de las pressuras, situa Sampaio el fenómeno de la abundante toponimia de "origen" visigodo en el Noroeste, como afirmó posteriormente J. Piel ${ }^{24}$. La idea de la "desorganización política y administrativa " y del "cambio de propietarios", en tierras ya habitadas desde antiguo, está presente también en los trabajos de P. David ${ }^{25}$. Este investigador, a parte de diferenciar lo que él define como la "colonización episcopal" (que probaría la'continuidad' del poblamiento) y la "colonización real", introduce otro argumento de peso contra la idea de la "despoblación": la continuidad de las advocaciones en las iglesias, lo que no puede explicarse, según P. David, sin la permanencia de la población ${ }^{26}$. También, A. de Jesus da Costa en su Tesis doctoral ${ }^{27}$

${ }^{22}$ A. SAmpaio, As 'villas' do Norte de Portugal, "Portugalia", I (1899-1903), pp. 97-128, 281-324, 549-584, 757-806.

${ }^{23}$ A. Sampaio, As 'villas' Norte de Portugal, op. cit., p. 285. Como vemos, los argumentos esgrimidos recientemente por la historiografía contra las tesis albornocianas, han sido ya empleados hace casi un siglo por A. Sampaio. Que la "lectura atenta" de la documentación no permitía sostener la tesis de la "despoblación" y posterior "repoblación", es un argumento y método de trabajo que debemos al extraordinario investigador portugués. Justo es reconocérselo y subrayarlo, algo que no ha sido hecho por la mayoría de los medievalistas españoles a la hora de abordar el polémico tema.

${ }^{24} \mathrm{~J}$. PIEL, Os nomes germânicos na toponimia portuguesa, Lisboa, 1936-1945; IDEM, Nomes de "possesores" latino-cristiãos na toponimia asturo-galego-portuguêsa, Coimbra, 1948. No obstante, J.Piel ha cambiado radicalmente las opiniones expresadas en esas obras y, finalmente, considera que la casi totalidad de esta toponimia tiene, efectivamente, su origen en la época visigoda y no en la de las pressuras: J. PIEL-D. KREMER, Hispanogotisches Namenbuch. Der Niederschlag des Westgotischen in den alten und heutigen Personen und Orstnamen der Iberischen Halbinsel, Heidelberg, 1976.

${ }^{25} \mathrm{P}$. DAviD, Études historiques sur la Galice et le Portugal du VIr au XII siècles, ParísLisboa, 1947.

${ }^{26}$ Ibidem.

${ }^{27} \mathrm{~A}$. de JESÚS DA COSTA, O Bispo D.Pedro e a organização da diocese de Braga, 2 vols., Coimbra, 1959. 
considera que la "desorganización política y administrativa" y la "ausencia de poder", son las únicas consecuencias de los acontecimientos de principios y mediados del s. VIII ${ }^{28}$. Además de coincidir con los argumentos de A. Sampaio y de P. David, A. de Jesus da Costa utiliza un documento excepcional (tanto o más que el denominado Parroquial Suevo): el Censual de la diócesis de Braga de finales del siglo $\mathrm{XI}^{29}$, que muestra una extraordinaria densidad de parroquias para ese momento, precisamente entre los ríos Limia y Ave (Figs. 2 y 3) y que constituye otro argumento de peso contra la tesis de "despoblación" y de la "repoblación"30, se situan asimismo en la posición contraria a Sánchez Albornoz a través de una lectura menos "literal" de los mismos documentos utilizados por él. Precisamente, la idea de un carácter laudativo y mítico de las crónicas asturianas así como el análisis filológico de la toponimia, son los principales argumentos con los que R.Menéndez Pidal va a combatir la tesis de la "despoblación" y de la "repoblación"31. A todos estos historiadores, filólogos y geógrafos portugueses, incluso a T. de Sousa Soares que al comienzo se alineaba con la tesis de la "despoblación" radical ${ }^{32}$, los califica Sánchez Albornoz de "nacionalistas" ${ }^{33}$, de "manipular" y de "retorcer" los textos ${ }^{34}$. Por el contrario, Sánchez Albornoz reserva a R. Menéndez Pidal una 'respetuosa réplica, ${ }^{35}$ en la cual recurre, una vez más, a la interpretación'literal' de las crónicas

\footnotetext{
${ }^{28}$ Ibidem.

${ }^{29}$ Ibidem.

${ }^{30}$ Ibidem. En otros trabajos más recientes el autor se reafirma en sus argumentos contra la imposibilidad de la"despoblación" y utiliza los vestigios de culto para apoyar su demostración: A. de Jesús Da Costa, A comarca eclesiastica de Valença do Minho (Antecedentes da diocese de Viana do Castelo), "I ${ }^{\text {er }}$ Coloquio Galaico Minhoto", Ponte de Lima, 1981, pp. 69-240; IDEM, Povoamento e colonização do territorio Vimaranense nos séculos IX a XI, "Actas do Congresso Historico de Guimarães e a sua Colegiada", III, Guimarães, 1981, pp. 135-196; IDEM, O Bispo D.Pedro e a organização da diocese de Braga, "IX Centenario da dedicação da diocese de Braga", I, Braga, 1990, pp. 379-434.

${ }^{31}$ R. MENÉNDEZ PIDAL, Repoblación y tradición en la cuenca del Duero, "Enciclopedia lingüística Hispánica", I, Madrid, 1960, pp. 29-57.

${ }^{32} \mathrm{~T}$. de SOUSA SOARES, O repovoamento do norte de Portugal no século IX, "Biblos", XVIII, 1942, pp. 5-26.

${ }^{33}$ C. SÁnCheZ Albornoz, Despoblación y Repoblación, op. cit., p. 219.

${ }^{34}$ Ibidem.

${ }^{35}$ Ibidem, pp. 155-187.
} 
y los documentos que hablan de la "despoblación"36, pero también al "multisecular vacío de población" del valle del Duero ${ }^{37}$.

Otra etapa, en la historiografía de este polémico tema, es la que van a abrir A. Barbero y M. Vigil con sus trabajos sobre los orígenes de la "Reconquista"38 y la formación del feudalismo ${ }^{39}$. Estos historiadores inaugurarán una serie de modelos interpretativos contra la tesis de la "despoblación" y de la "repoblación" del valle del Duero. Utilizan los mismos documentos y los "interpretan" bajo otros ojos más críticos, pero no menos subjetivos que los de Sánchez Albornoz. Como acertadamente ha expresado Henri Irénée Marrou "l' histoire est inséparable de l'historien", y además "toute histoire est histoire contemporaine" 40 .

Ciertamente, con A. Barbero y M. Vigil estamos ante un 'tournant' en la historiografía sobre el tema. A partir de sus obras, los historiadores y medievalistas españoles y portugueses han "decidido" que era posible (utilizando los mismos documentos empleados por Sánchez Albornoz) sostener una tesis contraria a la de éste, es decir:la imposibilidad del "despoblamiento" radical del valle del Duero. Las pruebas: "los mismos documentos son la mejor prueba a contrario". La totalidad, sin excepción,de los trabajos que abordan el problema de la tesis albornociana presentan interpretaciones unilaterales ${ }^{41}$. Ya se ha convertido en un lugar común decir "como todo el mundo sabe, actualmente nadie cree $^{42}$, en la "despoblación" radical defendida por Sánchez Albornoz; una relectura más atenta y profunda de la documentación lo muestra con claridad" ${ }^{43}$. Hay, incluso, historiadores

\footnotetext{
${ }^{36}$ Ibidem.

${ }^{37}$ Ibidem, pp. 167, 178-179.

${ }^{38}$ A. BARBERO-M. VIGIL, Sobre los orígenes sociales de la Reconquista, Barcelona, 1974.

${ }^{39}$ IDEM, La formación del feudalismo en la Península Ibérica, Barcelona, 1976.

${ }^{40}$ H.-I. MARrou, De la connaissance historique, Paris, 1966, pp. 51, 97 y 107.

${ }^{41}$ Como ha señalado: J.A. GARCÍA DE CORTÁZAR, Las formas de organización social del valle del Duero, op. cit., pp. 15-16.

${ }^{42}$ Puesto que ahora se trata de creer en la tesis contraria (sin ofrecer otras pruebas que la misma documentación). Al menos, la tesis de Sánchez Albornoz tenía la ventaja de poder comprobar en los mismos textos la "realidad" de las expresiones que hacen referencia a la "despoblación" y a la "repoblación".

${ }^{43}$ Esta idea, con las mismas o similares palabras, está presente en la totalidad de los trabajos que abordan, directa o indirectamente, el estudio del poblamiento entre los ss. VIII y X (incluso si estos siglos son una simple introducción a un estudio de períodos posteriores) a partir de los textos. Podemos citar entre otros: J.M. Mínguez, La Reconquista, Madrid, 1989; IDEM, Innovación y pervivencia en la colonización del valle del Duero, op. cit., pp. 47-79; M.
} 
que continuan creyendo que la "explicación que ofrece Sánchez Albornoz es la más convincente y, en el estado actual dela investigación, irrefutable"44 (siguiendo la línea de S. de Moxó) ${ }^{45}$.

En toda esta producción historiográfica de los últimos 20 años debemos, sin duda, subrayar el trabajo de J.A. García de Cortázar sobre la organización social del espacio entre el Cantábrico y el Duero ${ }^{46}$. Con un profundo análisis del espacio del valle del Duero (histórico y geográfico), muy en la línea de los geógrafos portugueses, García de Cortazar traza un "cuadro hipotético" para la evolución del poblamiento durante los siglos VIII y IX: un hábitat disperso, una demografía débil (que también considera multisecular), pequeñas comunidades desestructuradas y desorganizadas sobre lugares de altura y con formas de hábitat de tipo rupestre ${ }^{47}$. Él no da pruebas, evidentemente, de la realidad de este tipo de poblamiento, ya que estamos hablando de una "hipótesis explicativa del silencio documental"48. García de Cortázar subraya, también, que estas pequeñas comunidades y sus

DURANY CASTRILlo, La región del Bierzo en los siglos centrales de la Edad Media 1070-1250, Santiago de Compostela, 1989; P. MARTínEZ SOPENA, La Tierra de Campos occidental. Poblamiento, poder y comunidad del siglo X al XIII, Valladolid, 1985; J.A. GARCíA DE CORTÁZAR, La sociedad rural en la España medieval, Madrid (con una específica y abundante bibliografía); M.C. PALLARÉS MÉNDEZ, Organización social del territorio, "Historia de Galicia, I. De la Prehistoria a la Alta Edad Media", Vigo, 1991, p. 213- 232; IDEM-E. PORTELA Silva, Galicia na época medieval (Galicia Histórica, II), A Coruña; C. BÁLIÑAS, Do mito a realidade. A Definición Social e Territorial de Galicia na Alta Idade Media (séculos VIII-IX), Santiago de Compostela, 1992; E. PEÑA BOCOS, Las presuras y la 'repoblación' del valle del Duero: algunas cuestiones en torno a la atribución y organización social del espacio castellano en el siglo IX, "Repoblación y Reconquista del país" (III Curso de Cultura Medieval), Aguilar de Campoo, pp. 249-259; E. PASTOR DÍAZ DE GARAYO, Castilla en el tránsito de la Antigüedad al Feudalismo. Poblamiento, poder político y estructura social. Del Arlanza al Duero (siglos VII-XI) (Junta de Castilla y León. Consejería de Educación y Cultura. Estudios de Historia), Valladolid, 1996.

${ }^{44}$ Quien así se expresa es J.Gautier-Dalché, que añade: "...Dans l'état actuel des connaissances, l'hypothèse la plus plausible est celle de la désertion de la plupart des habitats qui avaient survécu jusqu'au milieu du VIII" siècle...", J. GAUTIER-DALCHÉ, Reconquête et structures de l'habitat en Castille, "Castrum 3: Guerre et fortification dans le monde méditerannéen au Moyen Âge" (Publications de la Casa de Velázquez-Série Archéologie-fasc. XII, Collection de l'École Française de Rome, 105), Roma-Madrid, 1988, pp. 199-206.

${ }^{45} \mathrm{~S}$. de Moxó, Repoblación y sociedad en la España cristiana medieval, Madrid, 1979.

${ }^{46}$ J. A. García DE CorTÁZAR, Del Cantábrico al Duero, "Organización social del espacio en la España Medieval. La Corona de Castila en los siglos VIII a XV", Barcelona, p. 43-83.

${ }^{47}$ Ibidem. Esta idea es retomada también en: IDEM, Las formas de organización social del espacio del valle del Duero, op. cit., pp. 16- 17.

${ }^{48}$ Ibidem. 
formas de habitación de tipo eremítico tienen un orígen en época visigo$\mathrm{da}^{49}$. Estas hipótesis son formuladas, por supuesto, a partir de una lectura más profunda de la documentación, que mostraría cómo los"repobladores" se instalan sobre sitios ya ocupados ${ }^{50}$. Lo que le falta a esta "hipótesis explicativa" es, precisamente, dar pruebas materiales de la realidad de este tipo de hábitat. Sin ellas, éstas no son más (ni menos) que el resultado de una excelente intuición y de un profundo conocimiento de la geografía del valle del Duero. A partir de esta hipótesis, J.Mattoso va a trazar, a su vez, un marco hipótético sobre la evolución del poblamiento rural para la parte costera del territorio entre el Miño y el Duero (la actual región portuguesa de Entre-Douro-e-Minho ${ }^{51}$. Con el método y los argumentos de García de Cortázar, traza para ese espacio una historia del poblamiento muy similar ${ }^{52}$.

En definitiva, actualmente, en nuestra opinión, el debate historiográfico sobre la "despoblación" y la "repoblación" del valle del Duero, se halla en un punto muerto y en un "diálogo de sordos". A las explicaciones unilaterales, señaladas por García de Cortázar, hay que añadir la existencia de hecho de una especie de consensus entre los medievalistas (" $\mathrm{l}$ l'histoire est inséparable de l'historien!") para hacer de la tesis de Sánchez Albornoz un "viejo debate superado y, sobre todo, no "en vogue"53. Así, todo el mundo se situa al lado de la "continuidad" y sólamente García de Cortázar y J. Mattoso han intentado ofrecer ${ }^{54}$, con mucha intuición, una historia verosí-

${ }^{49}$ Ibidem.

${ }^{50}$ Ibidem, p. 18.

${ }^{51} \mathrm{~J}$. Mattoso, Portugal no reino asturiano-leonês, "História de Portugal. I: Antes de Portugal (dir. J. Mattoso), Lisboa, 1993, pp. 444-447.

\section{${ }^{52}$ Ibidem.}

${ }^{53}$ Por el contrario, parece estar actualmente "en vogue" la crítica a los modelos o investigaciones venidas de más allá de los Pirineos y, más concretamente, procedentes de la historiografía francesa. Si bien su influencia haya sido excesiva en algunos trabajos de los años 70 , no es menos cierto que el medievalismo hispano es deudor de esa tradicion historiográfica. No debemos caer, por cuestiones de 'moda' o 'escuela', en el extremo contrario, es decir, en el rechazo sistemático de lo que no se 'concibe y hace' en España. Sin 'obsesionarse' por 'copiar' lo exterior, no se puede marginar e ignorar lo que se hace 'al otro lado de los Pirineos': "...una producción historiográfica, la hispana, que empieza a ensayar metodologías y modelos conceptuales propios, y deja de obsesionarse por copiar miméticamente planteamientos y resultados del quehacer científico desarrollado al otro lado de los Pirineos...",

E. PEÑa Bocos, La atribución social del espacio en la Castilla Altomedieval, op. cit., p. 343. ¡No olvidemos que Sánchez Albornoz también creía tener un 'modelo conceptual propio' que no admitía paralelos con lo que sucedía 'al otro lado de los Pirineos' ¡Hoy sabemos que no es así!

${ }^{54}$ Más allá de la visión reduccionista "ruptura" o "continuidad". 
mil del poblamiento en el valle del Duero durante los siglos VIII y IX. Sin embargo, no se dan pruebas; no se dice dónde estaba esa "población residual" durante el VIII y el IX; no se explica porqué los textos no mencionan a esos "hipotéticos habitantes del desierto del Duero, no se enlaza el hábitat de los siglos V al VII con el del VIII y IX... En resumen, no hay pruebas materiales concretas para hacer avanzar el debate más allá del reduccionismo "continuidad"-"ruptura".

1.2. Un modelo interpretativo para el espacio del Miño al Duero: la desestructuración del poblamiento antiguo y el desarrollo de un hábitat disperso y marginal.

\footnotetext{
...Les délicates questions d'origine...sont de celles qu'évite généralement un historien prudent. Sur de tels problèmes on ne peut souvent avancer que des hypothèses appelées à être plus tard confirmées ou infirmées. Il n'en est pas moins utile, d'essayer de composer un tableu cohérent des traits que, çà et là, on croit pouvoir distinguer...Attendre d'avoir en main toutes les conditions de la certitude, ce serait se condamner à ne jamais parler de pareils sujets ... (A. Grenier, Les Gaulois, Paris, 1945, p. 14 15).
}

$\mathrm{El}$ análisis del poblamiento entre el siglo $\mathrm{V}$ y finales del $\mathrm{VII}^{55}$ nos ha permitido observar cómo de una forma lenta, pero progresiva, la propia evolución interna del poblamiento rural durante la antigüedad tardía daba lugar a diferencias de orga-nización y de estructuración entre la parte costera del territorio entre el Miño y el Duero (la parte occidental del antiguo conventus bracarensis) y la parte interior y montañosa del mismo. El eje Ourense-Braga-Porto se constituye, durante ese período como el polo organizador de una jerarquización del territorio vinculada al proceso de cristianización rural ${ }^{56}$. Los grandes valles alrededor de este eje (en torno de los antiguos obispados - como Braga- y de los nuevos - como Ourense y Oporto-), evolucionan desde mediados del siglo VI hacia un espacio muy desarrollado y organizado ${ }^{57}$. Por el contrario, en el límite de esos valles, en los grandes sistemas montañosos, hemos constatado desde el siglo VII y sobre todo desde mediados de este siglo, otra organización y estructuración

\footnotetext{
${ }^{55}$ J. LóPEZ QUiRoga, Du Miño au Douro, op. cit., pp. 631- 707.

${ }^{56}$ Ibidem, pp. 631-683.

${ }^{57}$ Como ha sido señalado por P. David y muestra claramente el Parroquial Suevo: P. DAVID, Études historiques, op. cit.
} 
que había dado lugar a un tipo de poblamiento 'marginal' en relación al poblamiento romano predominante ${ }^{58}$. Se trata de un poblamiento con formas de habitación y una organización religiosa de inspiración fructuosiana. El orígen de este tipo de poblamiento está vinculado a la propia evolución del poblamiento rural tardo-romano y a una situación socio-política (la descomposición progresiva del Estado visigodo, por lo tanto, del Estado romano) ${ }^{59}$, económica (años de malas cosechas, plagas de Peste y de langosta $)^{60}$ y mental (pesimismo, ambiente de apocalipsis, catastrofismo) ${ }^{61}$, que constituye el contexto favorable a un deseo de huir de'les malheurs des temps'. En consecuencia, cada vez con mayor frecuencia las gentes se situarán al 'margen del sistema', en paisajes 'marginales' (incluso si estos

\footnotetext{
${ }^{58}$ J. LÓPEZ QUiroga, Du Miño au Douro, pp. 683-707.

${ }^{59} \mathrm{La}$ crisis institucional del Estado visigodo se hace particularmente visible desde mediados del siglo VII, con fenómenos como la revuelta de Sisnando (en Septimania) y la lucha por la sucesión al trono con Chindasvinto y Recesvinto entre el principio hereditario y el electivo (más de tipo germánico). Hacia mediados del s. VII, en torno al 653-654, la España visigoda bascula irremediablemente hacia la inestabilidad política. El principio de electividad (por tanto la 'germanización' del reino) triunfa y la Iglesia 'inventa' otra legitimidad para la elección a través de la sacralización. Es también hacia mediados de siglo cuando el reino visigodo y la Península girarán hacia el Imperio bizantino (se imita el sistema bizantino con la creación de provincias que tendrán funciones militares y a la cabeza de las cuales habrá cargos civiles, por ejemplo). La fragmentación territorial es bien visible en la repartición de los hallazgos monetarios de Rodrigo (710-711) y de Aquila (710-713), que muestra, en palabras de X. Barral i Altet, "...l'encerclement du royaume..." : X. BARRAL I ALTET, La circulation des monnaies suèves et wisigothiques, Munich, 1976.

${ }^{60} \mathrm{M}$. BARCEló, Les fléaux de llagost a la Carpetania, "Estudis d'Historia Agrària", I (1978), pp. 67-84; L. A. GARCÍA MORENO, El campesinado visigodo entre bajos rendimientos y catástrofes naturales. Su incidencia demográfica, "Antigüedad y Cristianismo", III, Murcia, 1986, pp. 171-187; P. BONNASSIE, Aquitaine et Espagne: pour une approche historique et archéologique de quelques grands problemes, "Gallo-romains, wisigoths et francs en Aquitaine, Septimanie et Espagne", Rouen, 1991, pp. 1-7; J. Le GofF-J.N. BIRABEN, La Peste dans le Haut Moyen Age, "Annales" (1969), pp. 1484-1510.

${ }^{61} \mathrm{M}$. Rouche, La crise de l'Europe au cours de la deuxième moitié du VII's. et la naissence des régionalismes, "Annales" (1986), pp. 347-360. Síntoma de esta extraordinaria crisis de civilización, visible en los momentos finales del reino visigodo, y del contexto mental de pesimismo y catastrofismo, queda reflejado en la legislación conciliar (y más concretamente en el canon XVI del I Concilio de Braga del 561), puesto que se condena a la excomunión a los suicidas (bien sea por arma blanca, con veneno, arrojándose a un precipicio o ahorcándose): "De his qui se ipsos interficiunt [De his qui sibi quaeumque violentia mortem inferunt ut earum commemoratio in oblatione non fiat, similiter et de his qui pro suis sceleribus puniuntur]. Item placuit, ut hii qui sibi ipsis aut per ferrum aut per praecipitium aut suspendium vel quolibetmodo violentiam inferunt mortem, nulla illis in oblatione commemoratio fiat neque cum psalmis ad sepultura meorum cadavera deducantur; multi enim hoc sibi per ignorantiam usurparunt. Similiter et de his placuit qui pro suis sceleribus puniuntur. J. VIVES, Concilios visigóticos $e$ hispano-romanos, Barcelona-Madrid, 1963, p. 10. ¡Es el primer canon de este tipo en toda la legislación conciliar!
} 
paisajes se situan en la extremidad de una villa romana, utilizada como cementerio o lugar de habitación con estructuras lígneas), con una forma de vida y una organización de tipo fructuosiano. Este proceso, que se desarrolla a lo largo de la antigüedad tardía ${ }^{62}$, se acentua desde mediados del s. $\mathrm{VII}^{63}$. Así, a finales del siglo VII y comienzos del VIII, en el territorio entre el Miño y el Duero, desde el punto de vista de la evolución del poblamiento es posible diferenciar dos zonas:

a) Por una parte, el eje Ourense-Braga-Oporto y los grandes valles que rodean esos obispados. Se trata de una zona muy desarrollada, estructurada y organizada (desde época romana), como el Parroquial Suevo nos lo muestra para mediados del siglo VI. En este espacio, las formas de ocupación del suelo y de poblamiento típicamente romanas son predominantes.

\footnotetext{
${ }^{62}$ J. LóPez QUiroga, Du Miño au Douro, pp. 631-707.

${ }^{63}$ En este sentido, el papel de Fructuoso (que analizaremos en otro estudio actualmente en preparación) es capital. En efecto, Fructuoso frente al Estado visigodo (sucesor y continuador, no lo olvidemos, del Estado romano) un 'marginal' cuya actividad se desarrolla, hasta su nombramiento como obispo de Braga, fundamentalmente en paisajes 'marginales' (la Vita Fructuosi está plagada de referencias a estos paisajes 'marginales'). Además, Fructuoso constituía un 'peligro' para el Estado visigodo, puesto que la extraordinaria proliferación y difusión de los monasterios que seguían su regla y con ella la numerosa incorporación de laicos que se hacían 'monjes', representaba una clara huída del servicio militar y del pago del impuesto (esto es también visible en la Vita Fructuosi: "Nisi et duces exercitus prouinciae illius uel circumseptus undique confinibus regi clamassent ut aliquantum proiberetur, -quia si fas fuerit permissionis non esset qui in expeditione publica proficisceretur- innumerabilis se debuit congregare exercitus monacorum": M.C. DíAZ Y DíAZ, La vida de S.Fructuoso de Braga. Estudio y edición crítica, Braga, 1974), en unos momentos críticos para el reino de Toledo. Que Fructuoso era un 'peligro' para el Estado visigodo (no olvidemos que su familia procedía de la Septimania y que nos es improbable que hayan apoyado la revuelta de Sisnando), lo prueba claramente que se le prohiba salir de la Península para Oriente, con la excusa de que un hombre tan brillante no podía abandonar la Península (Vita Fructuosi: "succendit eum inmensus sancti desiderii ardor ut partem occupans Orientis nouam arriperet peregrinationem. Quumque haec cum paucis et electis discipulis suispertractasset et nauem sibi ad subuectionem praeparasset quam omni praedestinatione ascendens transfretaret ad Orientem, ab uno proditore detectus discipulo egressionis aditum non ualuit impetrare. Quid multa? Quum haec agerentur, peruenit ad regis temporis illius auditum; formidans igitur rex et omnes prudentes illi familiariter adsistentes ne talis lux Spania desolaret, iussit eum sine aliqua molestiae perturbatione conprehendi et ad se usque perducere": M.C. Díaz y Díaz, La vida de S. Fructuoso de Braga, op. cit.). Es muy clara, en este sentido, la Ley del Código de Recesvinto (L, II, I, VII) que considera 'traidor' y potencial opositor político a todo aquel que intente salir de la Península. Resulta lógico, en ese contexto, nombrar a Fructuoso obispo de Braga, muy a su pesar (Vita Fructuosi: "Post haec uidelicet, licet inuitus, contra uoluntatem suam langoris merore depressus perniciter resistendo in sede metropolitana dono dei ordinatusest pontifex": M.C. DíAZ Y DíAZ, La vida de S. Fructuoso de Braga, op. cit.), como única manera de 'reintegrarlo' en el 'sistema'.
} 
b) Por otra parte, los grandes sistemas montañosos al límite de los valles que rodean esos obispados, y la mayor parte de la zona interior del territorio entre el Miño y el Duero (la parte oriental del antiguo conventus bracarensis, es decir, las actuales regiones portuguesas de Tras-os-Montes y del Alto Douro). Se trata de un espacio con un desarrollo, una organización y una estructuración totalmente diferentes. Aquí, desde mediados del siglo VII ${ }^{64}$, surge un tipo de poblamiento 'marginal'en paisajes ${ }^{65}$ y con formas de habitación típicamente fructuosianas. No estamos hablando de eremitas $^{66}$, sino de pequeñas comunidades mixtas que se situan al'margen' o en las 'fronteras' del paisaje romano predominante.

Cuando los Árabes llegan a la Península, desde el 714 en lo que concierne al Noroeste ${ }^{67}$ y desde el 716 en lo que respecta al territorio entre el Miño y el Duero ${ }^{68}$, y Alfonso I (739-757) con su hermano Fruela efectuan a mediados del siglo VIII una serie de razzias 'devastadoras' sobre una serie de ciudades del valle del Duero ${ }^{69}$, las consecuencias en las dos V-VII).

${ }^{64}$ En un proceso lento y progresivo que se desarrolla durante toda la Antigüedad tardía (ss.

${ }^{65}$ Sobre este paisaje 'marginal' y sus implicaciones para la comprensión del poblamiento durante la Antigüedad tardía y la alta Edad Media: G. Traiana, 'Continuità' et 'visibilità': premesse per una discussione sul paesaggio antico, "Archeologia Medievale", XVI (1986), pp. 685-693. Una aplicación de estos criterios de análisis en el Sureste de la Península en: S. GUTIÉRREZ LlORET, La Cora de Tudmir de la Antigüedad tardía al mundo islámico. Poblamiento y cultura material (Collection Casa de Velázquez, 57), Madrid, 1996.

${ }^{66}$ Una nueva y enriquecedora interpretación sobre el papel de los 'eremitas' en la evolución del poblamiento altomedieval: J. HEUCLIN, Aux origines monastiques de la Gaule du Nord. Ermites et reclus $d u V^{\prime \prime}$ au $X^{\prime} s$., Lille, 1988, pp. 67 y ss.

${ }^{67}$ Los Árabes no han penetrado en el Noroeste antes de la campaña de Musa en el 714 (las de Tariq en el 711 y 712 sólo llegarían hasta Astorga, según Sánchez Albornoz). Pero, en esta campaña Musa se habría dirigido hacia Lugo desde Astorga (siguiendo la vía que unía Lucus con Asturica), por lo tanto, el territorio entre el Miño y el Duero no habría sufrido en este momento las consecuencias de esta campaña: C. SÁNCHEZ ALBORNOZ, Itinerario de la conquista de España por los musulmanes, "Cuadernos de Historia de España", VII (1947), pp. 21- 57.

${ }^{68}$ Sólo un documento, considerado completamente falso por L. Barrau-Dihigo, nos informa de una supuesta campaña de Abd-el-Aziz en 716, en la cual éste habría 'arrasado' las ciudades de Oporto, Braga, Tui, Lugo y Ourense: L. BARRAU-Dihigo, Recherches sur l' histoire politique du royaume asturien (718-910), Tours, 1921, p. 110 (nota $n^{\circ} 2$ ).

${ }^{69} " .$. qui cum frate Froilane saepius exercitum movens, multas civitates bellando cepit, id est: Lucum, Tudem, Portugalem, Anegiam, Bracaram Metropolitanam, Viseo, Flavias...seu castra cum villis et viculis suis omnes quoque Arabes gladio interfeciens, Christianos autem 
zonas que hemos señalado (los grandes valles alrededor de los obispados, por una parte; y los grandes sistemas montañosos juntamentecon la mayor parte del interior del antiguo conventus bracarensis, por otra parte $)^{70}$, van a acelerar el doble proceso de evolución interna del poblamiento rural tardoantiguo que se observa desde el siglo VII y, sobre todo, desde mediados de ese siglo:

a) La desestructuración del poblamiento antiguo.

b) El desarrollo masivo de un hábitat disperso y marginal.

Son éstas, en nuestra opinión, las consecuencias 'reales' de unos acontecimientos tan magnificados (por las Crónicas y los propios textos contemporáneos, y por una línea historiográfica que comienza con Herculano y continua con Sánchez Albornoz hasta S. de Moxó), como la invasión árabe y las campañas de Alfonso I, ya que estos dos acontecimientos de comienzos y mediados del s. VIII (en lo que respecta a la evolución de las estructuras socio-políticas) no hacen mas que dar el golpe definitivo a una situación que se degradaba progresivamente desde mediados del s. VII (a nivel de las estructuras socio-políticas, económicas y mentales). No es, por lo tanto, posible explicar la situación del poblamiento en los s. VIII y IX, exclusivamente a partir de un análisis mas 'profundo' de los textos (especialmente los del s. X); porque si no se conoce la situación existente desde el s. VII, es muy difícil, por no decir imposible, trazar una historia del poblamiento entre los s. V y X. Normalmente, la historiografía nos ofrece dos historias: entre el comienzo del $\mathrm{V}$ y finales del VII - comienzos del VIII, por una parte, $\mathrm{y}$ entre el VIII y finales del $\mathrm{X}-$ comienzos del XI, por otra. El modelo interpetativo que nosotros queremos proponer, a partir del análisis del espacio entre el Miño y el Duero, intenta construir una sola historia del poblamiento entre el s. V y X,puesto que en el s. VIII no hay una 'continuidad' o una 'ruptura', sino el desarrollo (quizás acelerado por acontecimientos bien conocidos) de ese doble proceso que hemos señalado y que nos es mas que la evolución interna del poblamiento rural romano. Es, precisamente, esa evolución, con las consecuencias de los referidos acontecimientos sobre la distribución y la organización del poblamiento, la que nos muestra la Fig. 4 , correspondiente a la repartición de los lugares con tumbas excavadas en

secum ad patriam ducens...", Y. BonNAZ, Chroniques Asturiennes. Fin IX' siècle, CNRS, París, 1989, p. 45.

${ }^{70} \mathrm{Y}$ sobre la situación del poblamiento existente desde mediados del siglo VII y a comienzos del VIII. 
la roca: se trata de más de 200 pequeños cementerios (para el espacio entre el Miño y el Duero) utilizados por las gentes que ahí se enterraron durante los siglos VIII y IX ${ }^{71}$. En algunos casos, estos lugares han sido utilizados desde el s. VII, como ya hemos indicado. La situación que nos presenta la Fig. 4 no surge de golpe a mediados del VIII, puesto que este tipo de poblamiento 'marginal' y este hábitat disperso es el resultado,insistimos en ello, de la evolución del poblamiento rural romano ${ }^{72}$. La distribución espacial de estos lugares sobre la Fig. 4, nos muestra las zonas que han quedado al margen de los procesos de cambio (sobre la organización, la estructuración y la jerarquización del territorio y del poblamiento en relación con el proceso de cristianización) introducidos por los nuevos polos de organización territorial (los obispados desde mediados del VI y los monasterios con los valles circundantes al pie de los grandes sistemas montañosos desde finales del IX y, sobre todo, desde el s. X):

-el territorio situado entre la desembocadura de los ríos Miño y Limia.

- alrededor de la desembocadura del Támega y entorno a la Serra do Marão y de Vilarinho.

- alrededor de la Sierra de Larouco.

- alrededor de la desembocadura de los ríos Tua y Sabor-Vilariça.

En efecto, estas zonas van a quedar al margen del vasto proceso de reorganización territorial (conocido como "Reconquista" y "Repoblación") que va a tener lugar, en lo que al territorio entre el Miño y el Duero se refiere, desde finales del siglo IX y durante todo el X. Así, si comparamos la Fig. 4 (con esos más de 200 lugares donde encontramos cementerios correspondientes a pequeñas comunidades rurales dispersas) con las Fig. correspondientes a los elementos que van a caracterizar este vasto proceso de reorganización territorial desde finales del IX, podemos observar dos tipos de estructuración del territorio y de poblamiento completamente diferentes:

-la Fig. 5 (vestigios y edificios de culto) nos muestra, nuevamente, el eje Ourense-Braga-Oporto, con concentraciones significativas alrededor de los obispados y en los valles que los rodean.

\footnotetext{
${ }^{71} \mathrm{Y}$ posteriormente, puesto que, como veremos, este tipo de poblamiento plantea el problema de los 'despoblados' y de la fecha de su abandono.

${ }^{72}$ J. LÓPEZ QUIROGA, Du Miño au Douro, op.cit., pp. 683-707.
} 
-la Fig. 6 (los vestigios y edificios de culto mozárabes), nos ofrece la misma imagen. Este mapa es una prueba clara de que las tumbas antropomorfas excavadas enla roca no son las inhumaciones de los mozárabes $^{73}$. Ello es totalmente lógico, ya que se trata de fenómenos temporalmente diferentes ${ }^{74}$.

-la Fig. 7 (las ecclesias a partir de los textos) ${ }^{75}$, nos muestran también las zonas de los grandes valles alrededor de los obispados o de los nuevos polos de organización territorial como el monasterio de Celanova o de Guimarães.

- la serie de mapas concernientes a las villas mencionadas en los textos $^{76}$, no hacen sino confirmar un tipo de organización y de poblamiento que no tiene nada que ver con el que nos muestra la Fig. 4 (las tumbas excavadas en la roca). Por lo tanto, las Figs. 8, 9, 10, 11 y 12, nos muestran siempre las mismas zonas alrededor de los antiguos obispados y de importantes centros monásticos (como Celanova y Guimarães) y los grandes valles situados al pie de los grandes sistemas montañosos.

Si se quiere ver en esos más de 200 lugares - siempre en sitios con una topografía elevada: bien en la parte mas elevada de antiguas villae romanas $^{77}$, bien sobre espolones rocosos al borde de la costa atlántica ${ }^{78}$,

\footnotetext{
${ }^{73} \mathrm{~A}$ parte de que este tipo de tumbas son frecuentes también fuera de la Península Ibérica, en el Sur de Francia y hasta en Alsacia. ¿Que sepamos, en estos lugares no ha habido mozárabes!

${ }^{74}$ Volveremos sobre ello en el momento de analizar el poblamiento de finales del s. IX y durante el $\mathrm{X}$

${ }^{75}$ Una parte, evidentemente, de las ecclesias mencionadas en los textos. Nuestro objetivo no es localizar todos los lugares mencionados en la documentación, sino ofrecer las tendencias en la evolución del poblamiento y las zonas principales. Habría sido imposible (y, por otra parte, no existe ningún trabajo que haya localizado todos los topónimos de la documentación sobre su zona de estudio) querer localizar y representar todas las ecclesias mencionadas en los textos de finales del IX y del X. Por otra parte, ello no cambiaría sustancialmente la imagen que nos ofrece la Fig. 7, es decir, las zonas sobre las que se efectua el vasto proceso de reorganización territorial y del poblamiento efectuado por la monarquía astur-leonesa, en el espacio entre el Miño y el Duero.

${ }^{76}$ Son válidas la consideraciones hechas en la nota precedente: cfr. supra nota $\mathrm{n}^{0} 75$.

${ }^{77}$ Como, por ejemplo, en Muimenta (Vilela, Cualedro, Fig. $4, \mathrm{n}^{\circ} 230$ ) o en Pardieiros (Gudín, Xinzo de Limia, Fig. 4, $\mathrm{n}^{\circ} 735$ ).

${ }^{78}$ Como, por ejemplo, en el 'Alto do Gorito' (Seixas, Caminha, Viana do Castelo, Fig. 4, $n^{\circ}$ 164), en Vilar de Mouros (Caminha, Viana do Castelo), en Espilrrada (Monte da Agrichousa, Afife, Viana do Castelo, Fig. 4, n ${ }^{\circ}$ 624), en Pia dos Eidos (Areosa, Viana do Castelo, Fig. 4, n ${ }^{\circ} 630$ ), en Carreão (Viana do Castelo, Fig. 4, $n^{\circ} 633$ ) o en Santa Luzia (Viana do Castelo, Fig. 4, $\mathrm{n}^{\circ}$ 652).
} 
bien sobre antiguos castros ${ }^{79}$, bien a proximidad de monumentos megalíti$\cos ^{80}$, bien sobre montes ${ }^{81}$, bien sobre roquedos casi inaccesibles ${ }^{82}$, bien

\footnotetext{
${ }^{79}$ Como, por ejemplo, en San Salvador dos Penedos (Allariz, Fig. 4, $n^{\circ}$ 5), en el 'Alto do Louredo'(Louredo, Amarante, Fig. 4, n ${ }^{\circ}$ 12), en el castro de Santa Marinha (Casanova, Armeses, Maside, Fig. 4, n ${ }^{\circ} 363$ ), en el castro de Donões (Vila Real, Fig. 4, n ${ }^{\circ} 400$ ), en el castro de Monterrei (Moterrei, Ourense, Fig. 4, no 414), en el castro das Chás (Santa Mariña das Neves das Chás, Oimbra, Fig. 4, no 428), en el castro de 'coto d'Astrés' (Vilar, Ourense, Fig. 4, $\mathrm{n}^{\circ} 440$ ), en el Castro de Sanfins (Sanfins de Ferreira, Paáos de Ferreira, Fig. 4, no 444), en el castro de Venade (Ferreira, Paredes de Coura, Viana do Castelo, Fig. 4, no 459), en el castro de Bruzendes (Linhares, Paredes de Coura Viana do Castelo, Fig. 4, no 460), en el castro de Eja (Eja, Penafiel, Fig. 4, n⿳4070), en el castro de Genso (Couto, Refoios de Lima, Ponte de Lima, Fig. 4, $n^{\circ}$ 515), en el castro de Pedrosa (Trasestrada, Rios, Fig. 4, $n^{\circ}$ 561), en el castro da 'Derruida' (Horta da Vilariça, Torre de Moncorvo, Fig. 4, $\mathrm{n}^{\circ}$ 591), en el castro de Baldoeiro (Horta da Vilariça, T. de Moncorvo, Fig. 4, $n^{0}$ 592) o en el castro de Florderrei (Arzádigos, Villardevós, Fig. 4, no 730).

${ }^{80}$ Como, por ejemplo, en la Serra da Aboboreira (entre Baiao y Marco de Canaveses, Fig. $4, n^{\circ} 233$ ), en Portela de Santa Marta o Portela do Forno dos Mouros (Santa Marta, Penafiel, Fig. 4, no 484), en Carrazedo do Alvão (Soutelo de Aguiar, Vila Pouca de Aguiar, Fig. 4, n ${ }^{\circ}$ 694), o en Mouãos (Vila Real, Fig. 4, n 699).

${ }^{81}$ Como, por ejemplo, en Carvalha de Belhandro (Carvalho de Rei, Amarante, Fig. 4, ${ }^{0}$ 9), en el Alto das Igrejas (Azére, Arcos de Valdevez, Fig. 4, no 25), en Gardal (Gondoriz, A de Valdevez, Fig. 4, $n^{\circ}$ 31), en el Monte das Cruces (Grade, A.de Valdevez, Fig. 4, $n^{\circ} 32$ ), en el Alto do Castelo (capilla de São João, Frende, Baião, Fig. 4, $\mathrm{n}^{\circ} 45$ ), en el Outeiro de Baltar (Gomariz, Baltar, Fig. 4, $\mathrm{n}^{\circ} 49$ ), en Tosende (Baltar, Fig. 4, $\mathrm{n}^{\circ} 51$ ), en el Monte de Fraiães (Monte da Saia, Barcelos, Fig. 4, no 85), en el Alto do Chacim (Refojos de Basto, Cabeceiras de Basto, Fig. 4, $\mathrm{n}^{\circ}$ 156), en la Serra da Arga (Arga de Cima, Caminha, Fig. 4, $n^{\circ} 159$ ), en el Alto do Gorito (Seixas, Caminha, Fig. 4, $n^{\circ} 164$ ), en el Monte de São Paulo (Poiares, Freixo de Espada-à-Cinta, Fig. 4, $\mathrm{n}^{\circ}$ 255), en el Monte dos Pedrados (Penedo do Caixão, Serzedelo, Guimarães, Fig. 4, no 294), en el Monte da Serra da Aparecida (Vilar do Torno y Alentem, Lousada, Fig. 4, n ${ }^{\circ} 323$ ), en el Outeiro das Castanhas (Freixo, Marco de Canaveses, Fig. 4, $\mathrm{n}^{\circ}$ 341), en el Penedo da Rabela de Cima (Freixo, M. de Canaveses, Fig. $4, \mathrm{n}^{\circ} 333$ ), en el Monte das Coriscadas (Soalhães, M. de Canaveses, Fig. 4, $\mathrm{n}^{\circ} 345$ ), en el Monte de Pinhões (Soalhães, M.de Canaveses, Fig. 4348), en el Monte das Campas (Sobretâmega, M. de Canaveses, Fig. 4, n 352), en el Machorro das Cavadas (Varzeda do Douro, M. de Canaveses, Fig. 4, $n^{\circ}$ 359), en el Monte da Gaia (Perafita, Matosinhos, Fig. 4, $n^{\circ}$ 369), en el Cabeço de São Bras (Torre de Dona Chama, Mirandela, Fig. 4, n 381), en el Outeiro do Facho (Cortiáo, Cervos, Montealegre, Fig. 4, n⿳3 396), en el Outeiro do Rocho (Peireses, São Vicente da Châ, Montealegre, Fig. 4, n ${ }^{\circ}$ 397), en el Monte das Cotas (Travassos da Châ, São Vicente de Châ, Montealegre, Fig. 4, no 399), en Barreiros (Cabeça Santa, Penafiel, Fig. 4, no 463), en el Monte de Santo Ovidio (Arcocelo, Ponte de Lima, Fig. 4, $\mathrm{n}^{\mathrm{o}}$ 501), en el Monte do Castelo (Estorães, Ponte de Lima, Fig. 4, $\mathrm{n}^{\circ}$ 506), en el Monte do Caixão (Garfe, Povoa de Lanhoso, Fig. 4, n⿳ 535 ), en la Serra da Arca (São Lorenzo de Ribapinhão, Sabrosa, Fig. 4, $n^{\circ}$ 555), en el Monte das Freiras (Campo, Valongo, Fig. 4, $n^{\circ} 604$ ), en el Monte da Agrichousa (Afife, Viana do Castelo, Fig. 4, $\mathrm{n}^{\circ}$ 624), en el Alto do Calvario (Perre, Viana do Castelo, Fig. 4, n 648), en el Alto de São Cristovão (Ruivães, Vieira do Minho, Fig. $4, n^{\circ} 657$ ), en el Monte do Outeiro (Crestuma, Vila Nova da Gaia, Fig. 4, $n^{\circ} 680$ ).

${ }^{82}$ Como ejemplos paradigmáticos en este sentido podemos mencionar: San Victor de Ribas del Sil (San Lorenzo da Barxacoba, Parada del Sil, Fig. 4, $n^{\circ} 449$ ) o el Outeiro do Facho (Cortiço, Cervos, Montealegre, Fig. 4, n 396) situado a $1400 \mathrm{~m}$ de altitud.
} 
en relación con hábitats de tipo 'troglodita' ${ }^{83}$ o antiguas minas romanas ${ }^{84}$ los sitios donde se han instalado los pressores, los 'pioneros' de la colonización o incluso los 'proto-repobladores' ${ }^{85}$, habría entonces que explicar lo absurdo de instalarse sobre las peores zonas existentes para desarrollar la actividad típica de estos pressores, es decir, una agricultura vinculada a las mejores tierras de cultivo (como las Figs. 8, 9, 10, 11 y 12 lo muestran). Es imposible (y parafraseando a Sánchez Albornoz sería 'manipular' y 'retorcer' los hechos) ver en la Fig. 4 los lugares donde se han instalado los 'repobladores' (llamense pressores, 'pioneros' o proto-repobladores...), puesto que la Fig. 4 nos muestra un tipo de poblamiento en las zonas que han quedado al margen de ese vasto proceso de reorganización territorial que se efectua desde finales del IX y durante el $\mathrm{X}$ en el espacio entre el Miño y el Duero $^{86}$.

Por lo tanto, durante el siglo VIII y la mayor parte del IX podemos observar un doble fenómeno en la evolución del poblamiento rural, uno a partir de los textos y el otro a partir de la arqueología ${ }^{87}$ :

-la desestructuración del poblamiento típicamente romano, es el proceso que un análisis mas profundo de la documentación desde finales del IX (en lo que concierne a nuestro espacio de investigación) permite de

\footnotetext{
${ }^{83}$ Como en San Pedro de Rocas (Esgos, Ourense, Fig. 4, $n^{0} 236$ ), donde encontramos un ejemplo,también paradigmático, de este tipo de hábitat de inspiración fructuosiana y con un paisaje típicamente Capadociano (como el del Monasterio de San Pedro de Rodas, en Gerona), pero sin que podamos referirnos a la presencia de eremitas (como prueban claramente las tumbas antropomorfas excavadas en la roca pertenecientes a recién nacidos)

${ }^{84}$ Como en Nocelo da Pena (Sarreaus, Ourense, Fig. 4, $n^{0}$ 572), en Amonde (Viana do Castelo, Fig. 4, $n^{\circ}$ 627), en la Serra da Arca (São Lorenzo de Ribapinhão, Sabrosa, Fig. 4, $n^{\circ}$ 555 ), en Touças (Ribapinhão, Sabrosa, Fig. 4, no 556), en Gouvães da Serra (Vila Pouca de Aguiar, Fig. 4, no 692), en Povoaçao (Gouvães da Serra, V.P. de Aguiar, Fig. 4, n 693), en Carrazedo de Alvão (Soutelo de Aguiar, V.P. de Aguiar, Fig. 4, $n^{\circ}$ 694), en Lixa do Alvão (Soutelo de Aguiar, V.P. de Aguiar, Fig. 4, n 695), en Paredes de Alvão (Soutelo de Aguiar, V.P. de Aguiar, Fig. 4, no 696), en Mouços (Vila Real, Fig. 4, n⿳ 699), en Linhares (São Tomé do Castelo, Vila Real, Fig. 4, $n^{0} 700$ ), en Assento (Vale de Nogueiras, Fig. 4, $n^{\circ} 701$ ), en Carviçais (Torre de Moncorvo, Fig. 4, n ${ }^{\circ}$ 590), en Santa Marinha (Mos, T. de Moncorvo, Fig. 4, $\mathrm{n}^{\circ}$ 593), en Castrellos (T. de Moncorvo, Fig. 4, $\mathrm{n}^{\circ}$ 594), en la capilla de São Mamed (T. de Moncorvo, Fig. 4, $n^{\circ}$ 595), en Vila Velha (T. de Moncorvo, Fig. 4, $n^{\circ}$ 596), etc.

${ }^{85}$ Como subraya S. de Moxó, Repoblación y sociedad, op. cit.

${ }^{86}$ Estas zonas no serán afectadas, (¡cuándo lo han sido!) por este vasto proceso, antes de bien entrado el siglo XI o incluso el XII, como lo muestran el Cartulario del monasterio de Celanova y los documentos concernientes al espacio entre le Miño y el Duero y contenidos en el Portugalia Monumenta Historica.
}

${ }^{87}$ Dos fenómenos diferentes no excluyentes sino complementarios, ya que no se explica el uno sin el otro. 
entrever. Las zonas de los grandes valles alrededor de los obispados, aquellas que mostraban una mejor organización, estructuración y jerarquización (observable en el Parroquial Suevo), serán las más afectadas por los acontecimientos políticos de comienzos del siglo VIII y, sobre todo, de mediados de ese siglo, puesto que en estas zonas son solamente posibles una organización, un poblamiento y un tipo de economía (vinculada a las mejores tierras de cultivo) que con la nueva situación de inseguridad socio-económica permanente (no olvidemos que se trata de una zona de frontera entre la Cristiandad y el Islam) desde comienzos del VIII, ya no es posible. Estas zonas (alrededor de los obispados de Ourense, de Braga, de Oporto y de los fértiles valles que los rodean) han sido el lugar de paso obligado de las tropas cristianas y árabes pero también de las razzias normandas desde el siglo IX ${ }^{88}$. En estos obispados residían las autoridades políticas y religiosas que han huido al Norte del Miño: es lo que se denomina la desorganización política $^{89}$. A partir de estos obispados se había comenzado a efectuar un proceso de estructuración y de jerarquización del territorio ${ }^{90}$ que es ahora interrumpido como consecuencia de la huída de las élites dirigentes y de ausencia de un poder político y religioso sobre esos centros: es lo que se denomina la desorganización administrativa ${ }^{91}$. La casi totalidad de los documentos que poseemos desde finales del IX y durante el siglo $\mathrm{X}^{92}$, nos hablan de estas zonas ${ }^{93}$, ya que nos informan, precisamente, del proceso de

\footnotetext{
${ }_{i}^{88}$ Que han llegado hasta el monasterio de Guimarães! Precisamente, la construcción del castillo de Mons Latitio (en Guimarães) por la condesa Mumadona hacia mediados del siglo X es una consecuencia del ataque normando, con el objeto de defender el monasterio de Guimarães, según documento del 968: "...laboravimus castellum quod vocitant sanctum mames in locum predictum alpe latitio quod est super huius monasterio constructum et post defensaculo huius sancto cenobio concedimus cum fratibus et soribus in ipso monasterio persistentibus...", $\mathrm{PMH}, \mathrm{DC}, \mathrm{n}^{\circ} 97$.

${ }^{89} \mathrm{P}$. DAvid, Études historiques, op. cit.; A. de Jesús da CosTA, O Bispo D. Pedro, op. cit.; J. MATTOSo, Portugal no reino asturiano-leonês, op. cit.; J.A. GARCÍA DE CORTÁZAR, Del Cantábrico al Duero, op. cit. Suevo.

${ }^{90}$ En relación con el proceso de cristianización rural. Es la imagen que muestra el Parroquial

${ }^{91} \mathrm{Cfr}$. supra nota $\mathrm{n}^{\circ} 90$.

${ }^{92}$ Los contenidos en el Cartulario del monasterio de Celanova, en el Liber Fidei de la Catedral de Braga y en el "Portugalia Monumenta Historica". Para el espacio entre el Miño y el Duero, entre el 850 y el 1000 poseemos 326 documentos publicados, repartidos de la siguiente forma: 850-900: 11 documentos; 900-950: 76 documentos; 950-1000: 239 documentos.

${ }^{93} \mathrm{Como}$ en la Tierra de Campos, donde se constata una fuerte concentración de villas a lo largo de los valles del Cea y el Valdearaduey: P. MARTínez SopenA, La Tierra de Campos Occidental, op. cit., pp. 57-61.
} 
restauración del poblamiento antiguo (per suis terminis antiquis) y de la restauración de la red eclesiástica rural, a partir de los antiguos obispados (como Ourense, Braga, Oporto y también Chaves) ${ }^{94}$ y de las entidades monásticas (como Celanova o Guimarães). Los documentos, por lo tanto, nos muestran la continuidad del proceso iniciado desde mediados del s. VI y en la situación en que se había quedado cuando éste fue interrumpido a consecuencia de los acontecimientos de principios y mediados del siglo VIII. En definitiva, a partir de esa documentación, tenemos una imagen parcial sobre una parte del territorio del Miño al Duero, que deja al margen otras zonas (la mayor parte de nuestro espacio) que son las que no fueron inicialmente afectadas por el vasto proceso de reorganización territorial desde finales del IX y durante el s. X.

- el desarrollo de un hábitat disperso y marginal, es la imagen que la arqueología (Fig. 4) nos ofrece para esas zonas sobre las cuales los textos no hablan antes de, como mínimo, el siglo XI, en lo que respecta al territorio del Miño al Duero. Se trata de zonas donde desde mediados del VII había comenzado a desarrollarse un tipo depoblamiento vinculado a formas de habitación de tipo fructuosiano al 'margen' del poblamiento típicamente romano. Los acontecimientos de comienzos del VIII, de mediados de ese siglo y la situación socio-política y económica de inseguridad permanente que se instala, van a acelerar el desarrollo de un tipo de poblamiento al comienzo marginal (en relación al típicamente romano) y que ahora se convertirá en dominante, como la Fig. 4 nos muestra. Así, la dispersión del hábitat se acentua al extremo en comunidades desestructuradas política y administrativamente, pero con una organización religiosa de inspiración fructuosiana y una economía característica de tipo agropastora $1^{95}$. En estas comunidades los lugares de habitación (puesto que van a habitar en el interior de grutas, sobre espolones rocosos casi inaccesibles, sobre antiguos castros, en la parte mas elevada de antiguas villae romanas

\footnotetext{
${ }^{94}$ Puesto que se trata de restaurar los antiguos polos de organización territorial de época romana y Chaves lo fue, a pesar de haber sido sólo un efímero obispado.

${ }^{95}$ Como muestra la Vita Fructuosi y Valerio del Bierzo. Todo el texto de la Vita Fructuosi está plagado de referencias a un tipo de vida y de paisaje característicos: zonas de bosque, roquedos, grutas, lugares de alturas casi inaccesibles...: "...loca nemorosa, argis, densissima, aspera et fragosa per speluncas et rupes ..." (así se expresa cuando habla de los lugares a los que el santo 'huye' tras la fundación del monasterio de Compludo), " . .. remota solitudine in excelsorum montium sinibus ..." (lugar de la fundación del monasterio de Rufiana, identificado con San Pedro de Montes, en el Bierzo): M. C. DíAZ Y DíAZ, La vida de S. Fructuoso de Braga, op. cit., pp. 86 y 88 .
} 
y que van a construir sus casas rupestres con madera $)^{96}$ son menos importantes que el lugar de inhumación (puesto que van a excavar sus tumbas en la roca, que desde el siglo VIII se convierten en antropomorfas, ya que deben de ser bien visibles en el paisaje para luchar contra el olvido de los vivos en la esperanza de una 'muy próxima' resurrección). Esta es la razón por la que nosotros encontramos, normalmente, sus lugares de inhumación (bien visibles en el paisaje con el fin de perdurar el tiempo y en el espacio) y casi nunca sus lugares de habitación (de utilizacion temporal y carácter precario, por lo tanto, con el fin de desaparecer con el tiempo y en el espacio).

Este tipo de hábitat ahora dominante es el que hallaron las gentes que van a efectuar ese vasto proceso de reorganización territorial ${ }^{97}$ desde finales del siglo IX (en nuestro espacio objeto de estudio) y que a partir de ese

\footnotetext{
${ }^{96} \mathrm{La}$ idea de la huída hacia lugares elevados para 'escapar a los ojos humanos' y ser más visible a los 'ojos divinos', está también presente en la Vita Fructuosi: "... abditissima heremi loca petit ac fronduosis secretisque memoribus ita se occuli studuit ut nun altissimis locis, nun densissimis siluis, nunc etiam rupibus quae solis ibicibus peruiae sunt latebrando latitans ut non humanis sed diuinis oculis cerneretur ...", M.C. DíAZ Y DíAZ, La vida de S.Fructuso de Braga, op. cit., p. 93. La significación del monte en la mentalidad cristiana es observable en pasajes de la Biblia como el que es reproducido en las Actas del III $^{\text {er }}$ Concilio de Toledo en el 589: "... in novissimis diebus praeparatus mons domus Domini in vertice montium et elevabitur super colles et fluent ad eum omnes gentes et ibiunt populi multi et dicent: Venite ascendamus ad montem Domini et ad domun Dei Iacob...", J. VIVES, Concilios visigóticos e hispano-romanos, Barcelona, 1963, p. 142. La relación entre la topografía descrita por estos dos pasajes, entre otros numerosos, y la de las tumbas excavadas en la roca es más que evidente, a lo que se añade un contexto mental y un ambiente psicológico muy preciso y característico del período que venimos comentando.

${ }^{97}$ Pero no se trata, como decía Sánchez Albornoz, de gentes que han quedado en el valle de Miranda "...en ásperos y apartados lugares de la región en estudio algunos campesinos aferrados a sus viejas sedes;acaso ocurrió eso en el valle de Miranda y en otras zonas alejadas del tráfico del mundo...También hay oasis en los desiertos ...", C.SÁnCHEZ AlbORNOz, Despoblación y Repoblación, op. cit., p. 252 . La Fig. 4 no nos muestra un número reducido de sitios, y éstos no son siempre castros, como supone García de Cortazar: "...los pocos habitantes de los valles que decidieron continuar en su viejo solar. Mucho más numerosos... entre el Miño y el Duero... Aquí y en el resto de la meseta, en esos castros elevados, los encontraría la gente de Ordoño I y de Alfonso III...", J.A. GaRCía DE CORTÁzAR, Del Cantábrico al Duero, op. cit., p. 57. La razón del silencio documental no es tampoco, como subraya Gautier-Dalché, la presencia de 'raros grupos humanos': "...Les populatores, au nord du Douro d'abord, plus tard au sud, n'ont eu affaire qu'à des rares groupes humains trop peu nombreux pour qu' ils aient pu leur opposer une quelconque résistence et que pour cette raison les sources passent sous silence ...", J.GAUTIER-DALCHÉ, Reconquête et structures de l'habitat en Castille, op. cit., p. 201. La Fig. 4 es, en nuestra opinión y en lo que respecta al territorio entre el Miño y el Duero, la mejor prueba de la existencia de un poblamiento (no se trata de "oasis", ni de "raros grupos humanos", ni es exlcusivamente un poblamiento vinculado a antiguos castros) que no es reflejado en los textos y que no es posible explicar a partir del "análisis más profundo de la documentación".
} 
momento quedará nuevamente al margen de las zonas sobre las que ese proceso será efectuado (las que estaban mejor desarrolladas, organizadas y presentaban un mayor rendimiento desde mediados del VI). Este tipo de hábitat, que se debe de poner en relación con el fenómeno de ocupación o de reocupación de las alturas (incluso si se trata de alturas sólo topográficamente significativas) que se desarrolla progresivamente desde época tardoromana $^{98}$ y que es también una característica del hábitat Mediterráneo de este momento ${ }^{99}$. Se ha llegado incluso a considerar que se trataba de un fenómeno típicamente Mediterráneo ${ }^{100}$, pero podemos afirmar que esta también presente en el mundo atlántico. En efecto, en el territorio del Miño al Duero, se trata de una característica de la ocupación del suelo y del poblamiento durante todo el período comprendido entre los siglos $\mathrm{V}$ al $\mathrm{X}$, con momentos de especial intensidad en el s. V y en el VIII ${ }^{101}$.

Contrariamente a la opinión de otros investigadores no creemos que Sánchez Albornoz haya fundado su teoría 'sobre la nada' ${ }^{102}$, o que exista

\footnotetext{
${ }^{98} \mathrm{~A}$. Tranoy, La Galice romaine. Recherches sur le Nord-Ouest de la Péninsule Ibérique dans l'Antiquité, París, 1981.

${ }^{99} \mathrm{P}$.-A. FEVRIER, Problèmes de l'habitat du Midi Méditerranéen à la fin de l'Antiquité et dans le haut Moyen Âge, "Jahrbuch des Romisch-germanischen Zentralmuseum Mainz", 25 (1978), pp. 208-247; R. FOSSIER-J. CHAPELOT, Le village et la maison au Moyen Age, Poitiers, 1980; A. BAZZANA, Maisons d'Al-Andalus. Habitat médiéval et structures du peuplement dans l' Espagne orientale, (Collection de la Casa de Velazquez, 37), Madrid, 1992; IDEM-P. Cressier-P. GuiChARD, Les Châteaux ruraux d'Al-Andalus. Histoire et Archéologie des Husun du Sud-Est de l'Espagne (Publications de la Casa de Velázquez, Série Archéologie, XI) Madrid, 1988; R. FRANCOVICH (dir.), Scarlino I. Storia e Territorio, (Richerche di Archeologia Altomedievale e Medievale), Florencia, 1985; IDEM-M. MILANESE, Lo scavo Archeolo-gico di Montarreti e $i$ Problemi dell'incastellamento Medievale. Esperienze a confronto, "Archeologia Medievale", XVI (1989), pp. 9- 289; S. GuTIÉRREZ LlORET, La Cora de Tudmir de la Antigüedad tardía al mundo islámico. Poblamiento y cultura material, (Collection Casa de Velázquez, 57), Madrid, 1996 (con amplia y actualizada bibliografía).

${ }^{100}$ A. BAZZANA-G. NoYÉ (ed.), Castrum 2. Structures de l'habitat et occupation du sol dans les Pays méditerranéens: les méthodes et l'apport de l'archéologie extensive (Collection de l'École Française de Rome, 105. Publications de la Casa de Velázquez, Série Archéologie, fasc. IX ), Roma-Madrid, 1988

${ }^{101}$ J. L. QUiRogA, Du Miño au Douro, pp. 737-766; IDEM-M.R. Lovelle, Poblamiento rural en el noroeste de la Península Ibérica. Una introducción al estudio del poblamiento rural en la Alta Edad Media a partir de un análisis micro-regional (ss. V-X), "Boletín de Arqueología Medieval", 7 (1993), pp. 21-53.

${ }^{102}$ J.A. GuTIÉRREZ GONZÁLEZ, Fortificaciones y feudailsmo, op. cit., p. 101.
} 
un prejuicio explicativo que impida construir una historia de este período sobre nuevas bases ${ }^{103}$. En nuestra opinión Sánchez Albornoz hacía referencia a una evolución del poblamiento que sólo es posible aplicar a las zonas mencionadas en los textos. Efectivamente Sánchez Albornoz ha realizado una lectura 'literal' de los documentos y, ciertamente, una lectura más 'profunda' de éstos, muestra que la 'despoblación' y la 'repoblación' no son mas que una ficción jurídica para esconder la realidad de ese vasto proceso de reorganización territorial y de la restauración del poblamiento antiguo (el poblamiento característico de época romana) sobre nuevas bases y con otros protagonistas. Pero, no es menos cierto que en esas zonas alrededor de los antiguos obispados (Ourense, Braga, Porto y Chaves) y de los monasterios creados en este momento (como Celanova y Guimarães), la desorganización política y administrativa había sido muy fuerte (precisamente, como consecuencia de una previa organización política y administrativa muy desarrollada desde mediados del siglo VI). Así, podríamos decir que Sánchez Albornoz 'ha tomado la parte por el todo', además de ver en la 'desorganización' político-administrativa la 'despoblación' y en la reorganización territorial la 'repoblación'. Sin embargo, actualmente, todavía se sigue tomando la parte (las zonas donde hubo 'desorganización' y luego 'reorganización') por el todo (las zonas donde existía otra 'organización' y que han quedado, al comienzo, al margen del proceso de 'reorganización'). Se trata de una distorsión provocada por una visón basada en un tipo de fuentes (los textos) que la Fig.4 (la arqueología) puede, pensamos, ayudar a corregir.

El modelo interpretativo que hemos propuesto ${ }^{104}$ a partir del análisis del territorio entre el Miño y el Duero (el bajo valle del Duero geográfico), concerniente a la evolución del poblamiento rural durante el siglo VIII y la mayor parte del IX, nos plantea ciertas cuestiones ${ }^{105}$ :

1. ¿Durante cuanto tiempo ha permanecido este poblamiento 'marginal' y cuándo ha sido abandonado, una vez iniciado el proceso de 'reorganización' territorial desde finales del s. IX? Se trata, evidentemente,

\footnotetext{
${ }^{103}$ J. M. MíNGUEZ, Innovación y pervivencia, op. cit., p. 79.

${ }^{104} \mathrm{Y}$ que es necesario completar con otros análisis micro-regionales, teniendo, además, en cuenta que estamos hablando a nivel global para un gran espacio como es el territorio del Miño al Duero. Por lo tanto, es necesario relativizar los resultados de un análisis que esconde, sin duda, multitud de variantes zonales incluso locales, que será necesario verificar en investigaciones posteriores.

${ }^{105}$ Que son, al mismo tiempo, una serie de conclusiones en forma de preguntas.
} 
del problema de los 'despoblados' (la Wüstungsfrage) ${ }^{106}$. Nosotros hemos constatado que la mayor parte de los lugares donde se encuentran estos cementerios (Fig. 4) son hoy en día 'despoblados ${ }^{107}$. Como hipótesis, que es necesario verificar, pensamos que es posible relacionar una gran parte del abandono de esos lugares con el proceso de 'reorganización' territorial que tiene lugar entre el Miño y el Duero desde finales del siglo IX y que se continuará a lo largo de los siglos $\mathrm{X}$ y $\mathrm{XI}^{108}$. No deja de ser tentador relacionar un período de 'expansión demográfica y económica' con intensificación de los despoblados e, incluso, como sugiere P. Toubert, ver en la multiplicación delas deserciones un signo de crecimiento, en un momento

\footnotetext{
${ }^{106}$ Problema clave en la evolución del poblamiento medieval (y no solo bajo-medieval) como ha demostrado el Prof. W. Janssen en su modélico estudio sobre los 'despoblados' en la región del Eifel y Rhin en Alemania: W. JANSSEN, Studien zur Wästungsfrage im Fränkischen Altsiedelland zwischen Rhein, Mosel und Eifelnordrand (Beihefte der Bonner Jahrbücher, Band 35), 2 vol., Colonia-Bonn, 1975. El estudio de los despoblados es clave para la comprensión de la evolución del poblamiento: "...Strettamente connesso il tema precedente - spesso una casa isolata nella campagna è il resultato di un lungo processo di atrofizzazione di un villaggio- è quello dei siti abbandonati. Nonostante che le indagini sistematiche sui villages désertés siano oggi un po in declino, la loro prosecuzione - facilitata dall' affinarsi delle metodologie di superficie e di indagine sulle fonte scritte- appare indispensabile per la notevole importanza del fenomenodegli abbandoni nel contesto complessivo delle ristrurrurazioni del tessuto insediativo e della dinamica del popolamento nella regione padana..." R. COMBA, Archeologia e Storia delle campagne (secoli X-XV), "Archeologia Medievale", X (1983) (Actas del Coloquio: 'Archeologia Medievale nell'Italia settentrionale: il prossimo decennio, Pavia, 18-20 settembre 1981), pp. 94-95 (pp. 89-110, con una amplia y selecta bibliografía).

${ }^{107}$ Puesto que las recientes investigaciones han mostrado, para otras zonas, que estos cementerios aislados no son los antiguos cementerios de hábitats actuales sino de hábitats 'desaparecidos ' ('despoblados'). J.-M. PESEZ, L' habitat dispersé: un problème pour l'archéologie du village, "Flaran XVIII" (Actes du Colloque: L' habitat dispersé dans les campagnes de l'Europe médiévale et moderne, 1996 ), en prensa.

${ }^{108}$ En la región del Eifel, el Prof. W. Janssen ha conseguido datar con precisión 320 lugares despoblados (aldeas, granjas, molinos, lugares fortificados, 'industriales' y construcciones religiosas -iglesias y capillas-), que ha clasificado en bloques de medio siglo mediante una serie de diagramas que permiten ver las tendencias de los despoblados y sus períodos máximos en la 'longue durée', entre el siglo VI y el XX. Los dos diagramas más interesantes son el de los despoblados de aldeas (Dorfwüstungen) y el de las granjas (Hofwüstungen). Para las aldeas, la curva de Janssen muestra dos claros momentos álgidos: el siglo IX (sobre todo en su segunda mitad) y el siglo XIII, siendo este último siglo, el de mayor número de despoblados; por otra parte, casi no hay despoblados en el siglo X y a comienzos del XI. Tanto la curva de despoblados de granjas como la de molinos muestran tendencias similares a la de las aldeas. Es decir, que los momentos máximos de despoblados no se sitúan en el período 1300-1450 (considerado tradicionalmente como de depresión demográfica), sino con anterioridad, en el $\mathbf{s}$. IX y sobre todo, en el XIII (períodos considerados como de expansión demográfica y económica): W. JANSSEN Studien zur Wüstungsfrage, op. cit.
} 
dado $^{109}$. Para la historia del poblamiento entre Miño y Duero (y de una forma general para todo el valle del Duero), la confirmación de esta relación (expansión / deserción /crecimiento) y la de una segunda mitad del siglo IX como uno de los períodos característicos de despoblados, llevaría a replantearse la imagen ofrecida a partir de los textos y defendida por la mayor parte de los medievalistas.

2. ¿Cómo se integra ese poblamiento 'marginal' (cuando es mencionado en los textos) en la nueva organización estableciada por el proceso de 'reorganización' territorial desde finales del s. IX ? Nos referimos al problema de la evolución del hábitat disperso al hábitat concentrado, con todas sus multiples variantes micro-regionales y locales. Precisamente, el análisis de algunas zonas en el interior del territorio entre el Miño y el Duero ${ }^{110}$, nos ha permitido ver cómo desde finales del IX y, sobre todo, en el curso de IX hay un proceso de progresiva concentración del habitat en torno a las villae y a las ecclesias ${ }^{111}$.

3. Este poblamiento 'marginal' y disperso, ¿es la última etapa del poblamiento romano o la primera etapa del poblamiento medieval? ${ }^{112}$. Es el problema (en parte en relación con el primero que planteábamos) referente al papel jugado por el proceso de 'reorganización' territorial (lo que se denomina 'Reconquista' y 'Repoblación') desde finales del IX, en la interrupción de este tipo de poblamiento que es todavía 'dominante' en los

${ }^{109} \mathrm{P}$. TOUBERT, Problèmes actuels de la Wüstungsforschung, "Francia", 5 (1977), pp. 672 685. En Italia, en el bajo valle del Biferno, en Molise, se han constatado "...almeno due fasi di espansione caratterizzateda insediamenti abbandonati - uno nel periodo alto medievale, un altro nei secoli XV, XVI e XVII, quando l'espansione della popolazione costrinse a creare nuovi insediamenti in aree marginali ...", G. BARKER, $L^{\prime}$ archeologia del paesaggio italiano: nuovi orientamenti e recenti esperienze, "Archeologia Medievale", XIII (1986), p. 25 (pp. 7-30). De nuevo encontramos la relación entre períodos de expansión e intensificacion de los despoblados.

${ }^{110}$ J. LóPez Quiroga, Du Miño au Douro, op. cit., pp. 423-631.

"'Lo que no excluye la imagen de una dispersión de los lugares de habitación en el interior del espacio de la villa, como han demostrado E. Portela y M.C. Pallarés a partir de la documentación del Cartulario del monasterio de Samos, para la Galicia interior: E PORTELAM.C. Pallarés, Galicia en la época medieval, (Galicia Histórica, II), A Coruña, 1991. Es la misma imagen que se observa a partir del Cartulario del monasterio de Celanova, también en la Galicia interior.

${ }^{112}$ Como parece ser el caso de la Toscana: "...Intorno alla metà del VII secolo questa 'risalita' delle popolazioni delle pianure costiere alle alture immediatamente sovrastanti à un fatto compiuto e a questo periodo si riferisce il primo impianto medievale portato alla luce dagl scavi del castello di Scarlino, e datato fra la fine del VI e l'inizio del VII secolo ...", R. Francovich (dir.), Scarlino I. Storia e Territorio (Richerche di Archeologia Altomedievale e Medievale), Florencia, 1985, p. 301. 
siglos VIII y primera mitad del IX. Podríamos formular de otra forma la pregunta: La 'Reconquista' y la 'Repoblación' ¿provocan la 'ruptura' del poblamiento existente durante el siglo VIII y la primera mitad del IX ${ }^{113}$ ? En nuestra opinión, se trata de la última etapa del poblamiento romano, ya que la 'Reconquista' y la 'Repoblación' van a dar un golpe definitivo a este tipo de poblamiento que se desarrolla lenta pero progresivamente desde finales de la época romana. Tanto ésta como las cuestiones precedentes, solamente podrán ser resueltas con nuevas investigaciones y una metodología precisa que no se base exclusivamente en los mismos, y tan utilizados, documentos ${ }^{114}$.

\section{EL PROCESO DE REORGANIZACIÓN DEL POBLAMIENTO RURAL ENTRE EL MIÑO Y EL DUERO DESDE FINALES DEL $S$. IX A FINALES DEL $S$. $X$}

\subsection{La 'aparición' de las villae en los textos y la 'restauración' del poblamiento antiguo}

Desde finales del s. IX (Fig. 8) pero sobre todo durante todo el s. $\mathrm{X}$ (Fig. 9, 10, 11 y 12) ${ }^{115}$, la documentación nos informa sobre el fenómeno de 'aparición' de las villae ${ }^{116}$ en el territorio entre el Miño y el

\footnotetext{
${ }^{113} \mathrm{Y}$ que tiene su origen, como hemos señalado, en el siglo VII.

${ }^{114}$ Un método que siga el modelo de la investigación efectuada por el Prof. W. Janssen en el Eifel: W. JANSSEN, Studien zur Wüstungsfrage, op. cit., y los planteamientos conceptuales y metodológicosde la escuela de la Siedlungsforschung alemana. Una actualización de estos planteamientos en: D.DENECKE et alii: Wüstungsprozesse-Wüstungsperioden-Wüstungsräume, "Siedlungsforschung. Archäologie-Geschichte-Geographie", 12 (1994), pp. 9-235 (especialmente las contribuciones de D.Denecke: pp. 9-34; R. Bergmann: pp. 35-68; y G. Mangelsdorf: pp. 87-103).

${ }^{115}$ Como ya hemos indicado, los sitios representados en estos mapas (Figs. 9, 10, 11 y 12), no son la totalidad de los que son mencionados en los 326 documentos utilizados para finales del IX y, sobre todo, el s. X. Sin embargo, estos mapas muestran las zonas principales, en momentos diferentes en función de las propias menciones documentales, donde encontramos mencionadas estas villae en relación con el proceso de reorganización territorial desde finales del s. IX y durante el $\mathrm{s}$. X. La identificación del total de topónimos con el calificativo de villae no es el objetivo de este trabajo. Por otra parte, ello no hará sino añadir otroslugares en las mismas zonas que ya podemos apreciar a través de los mapas que hemos efectuado.

${ }^{116}$ Aparición en los textos, por supuesto.
} 
Duero. Se trata del proceso de 'restauración' del poblamiento ${ }^{117}$ antiguo en las mismas zonas caracterizadas por una ocupación del suelo y estructuración del poblamiento típicamente romanas ${ }^{118}$. Ello es consecuencia de este

\begin{abstract}
${ }^{117}$ Fenómeno muchas veces estudiado y analizado, de forma impecable, por excelentes medievalistas. No es cuestión de repetir aquí desarrollos y análisis bien conocidos. Todo ello forma parte de un tipo de investigación, y escuela, que ha permitido explicar la evolución de una parte del poblamiento existente a partir de los textos, pero ese tipo de análisis no ha permitido trazar una historia del poblamiento entre los ss. V y X (especialmente para el período del 750 al 850). Sobre todo lo concerniente a las villae, como unidad de habitación, de explotación agrícola y elemento clave en la organización del espacio: M.C. PALLARÉs-E, PORTELA, Aproximación al estudio de las explotaciones agrarias en Galicia de los siglos IX al XII, "Actas de las Iss Jornadas de Metodología aplicada a las Ciencias Históricas, II, Historia Medieval", Universidad de Santiago de Compostela, 1975, pp. 95-113; M.C. PALLARÉS, El poblamiento rural gallego, "Revista Obradoiro", 2 (1978), pp. 3-144; IDEM-E. PORTELA, Galicia na época medieval, op. cit.; C. BALIÑAS, Do mito a realidade, op. cit.; J.A. GARCÍA DE CORTÁzAR, Del Cantábrico al Duero, op. cit.; IDEM, La sociedad rural en la España medieval, Madrid, 1988; P. MARTínEZ SOPENA, La Tierra de Campos Occidental, op. cit.; M. DURANY CASTRILlo, La región del Bierzo, op. cit.; J.M. MíngUEZ, El dominio del monasterio de Sahagún en el siglo X. Paisajes agrarios, producción y expansión económica, Salamanca, 1980; E. PEÑA BOCOS, La atribución social del espacio, op. cit.; E. PASTOR DÍAZ DE GARAYO, Castilla en el tránsito de la Antigüedad al feudalismo, op. cit.; etc.
\end{abstract}

${ }^{118}$ Puesto que la romanización del noroeste peninsular (no solo del territorio del Miño al Duero que ha sido profundamente romanizado) es un hecho indudable. Trabajos recientes, tanto procedentes de historiadores de la Antigüedad como de altomedievalistas, tienden a hablar de la escasa romanización del noroeste y norte peninsular. Ello ha dado lugar a una nueva visión de un norte peninsular ajeno a los procesos de cambio que la romanización ha supuesto en otras zonas consideradas más profundamente romanizadas. Trabajos como los de G. Pereira Menaut, entre los especialistas en Historia Antigua, o los de J.M. Mínguez, C.Baliñas, E. Barrena Osoro, o más recientemente E. Peña Bocos, ofrecen una imagen del norte y del noroeste peninsular, como un espacio ajeno a esos procesos de cambio que mencionábamos: G. PEREIRA MENAUT, Historical landscape and structures. A reflection on the case of roman Galicia,"Boletín Auriense", X (1980), ppp. 25-32; IDEM, La formación histórica de los pueblos del Norte de Hispania. El caso de 'Gallaecia'como paradigma, "II Seminario de Arqueología del Noroeste", Madrid, 1983, pp. 169-192; IDEM-SANTOS YAGUAS, Sobre la romanización del Noroeste de la Peninsula Ibérica: las inscripciones con mención del origo personal, "Actas do Seminario de Arqueología del Noroeste", Madrid, 1980; J.M. MíngUEZ, La Reconquista, Madrid, 1989; IDEM, Las sociedades feudales. I. Antecedentes, formación y expansión (siglos VI a XII), "Historia de España", Madrid, 1994; IDEM, Innovación y pervivencia, op. cit., pp. 47-79; C. BALIÑAS, En los orígenes de un ecosistema social: la Galicia del siglo VIII, "El Museo de Pontevedra", XLIII, 1989, pp. 25 37; Ibd. Do mito a realidade. A definición Social e Territorial de Galicia na Alta Idade Media (séculos VIII e IX), Santiago de Compostela, 1992 E. BARRENA OSORO, La formación histórica de Guipúzcoa. Transformaciones en la organización social de un territorio cantábrico durante la época altomedieval, San Sebastián, 1989; E. PEÑA Bocos, La atribución social del espacio, op. cit. Es necesario decir, sin caer en el extremo contrario, que la arqueología no permite hablar de una escasa o nula romanización del norte y noroeste peninsular. Evidentemente, 'Roma solo hay una' y pretender encontrar huellas materiales y monumentos como los acostumbrados en otras zonas peninsulares o extra peninsulares, es someterse a un 'modelo ideal de romanización', frecuentemente instalado como esquema de trabajo utilizado en cualquier región: "...La mancata indagine sul terreno e d dettaglio sui materiali porta poi ad un'altra conseguenza, quella di generalizzare il modelo ideale della romanizzazione: quello che si fonda sulle grande arterie stradali, sulla centuriazione, sulle ville; modello che ci è stato tramandato direttamente dalle fonte classiche (Catone, Varrone i 
vasto proceso de reorganización territorial (que se denomina 'Reconquista' y 'Repoblación') realizado por la monarquía astur-leonesa desde finales del IX y durante todo el s. X, en lo que respecta al territorio entre el Miño y el Duero. Este proceso será efectuado, según la información de las Crónicas, en dos etapas:

a) entre el 865 y el 868 , se procede a la integración del espacio comprendido entre los ríos Miño y Limia en el espacio astur-leonés (bajo el reinado de Ordoño I, 850-866). En efecto, una vez situada la 'frontera' del reino en el tramo bajo del Miño y ocupada la importante ciudad episcopal de Tui por Hermenegildo Gutiérrez y Alfonso Betote entre el 860 y el $865^{119}$, se procederá a la integración de las tierras situadas entre los ríos Miño y Limia. Esta 'integración', que comienza con la ocupación de la ciudad episcopal de Ourense en el $865^{120}$, será efectuada entre el 866 y el 868 por un delegado del rey, y va a afectar a las zonas siguientes: los valles del curso medio del Miño ${ }^{121}$, el valle del Arnoya ${ }^{122}$ y el valle del Li-

Gromatici) e che senza dubbio è diffuso in molte regione dell'impero e certamente anche in molte zone di pianura dell'Italia settentrionale...ma tale modello è inadeguato per spiegare tutta una serie di condizioni economiche e sociali che si mantennero in altre zone...", G.P. BROGGIOlo, La campagna dalla tarda antichità al 900 CA.DC.,"Archeologia Medievale, X (1983), pp. 74-75 (pp. 73-88). No es lugar de extendernos sobre el tema, pero los hechos son tozudos y la arqueología poco a poco va descubriéndonos que 'lo romano' y la romanización (por muy 'diferente' y 'particular' que ésta sea) es un período por el que los pueblos del norte y noroeste peninsular también han pasado. Los descubrimientos arqueológicos efectuados en la urbe lucense (Lucus Augusti) en los últimos diez años (entre ellos, la determinación de la forma urbis de la ciudad, un rasgo indudable e incuestionable de su carácter romano y urbano), las recientes excavaciones en A Coruña, en Vigo, en Tui, en Ourense (por no hablar más que del 'mundo urbano' tan cuestionado para el noroeste), en Gijón, etc., no dejan lugar a dudas sobre la romanización del noroeste y otras zonas del norte peninsular. Para el noroeste: A RODRÍGUez Colmenero et alii: Lucus Augusti. Urbs romana. As oríxes da cidade de Lugo (Catálogo de exposición), Lugo, 1995 y las Actas del Congreso Internacional celebrado en Lugo en Mayo de 1996: Los orígenes de la ciudad en el noroeste hispánico, Lugo, en prensa (con contribuciones sobre los recientes hallazgos para el ámbito del noroeste y norte peninsular que cuestionan la visión de un espacio 'poco o nada romanizado'). También: J. NOVO GUISÁN, Los pueblos Vasco-Cantábricos y Galaicos..., op. cit. (con una amplia bibliografía y exposición de los hallazgos de época romana existentes en ese espacio).

${ }^{119} \mathrm{C}$. BALIÑAS, Do mito a realidade, op. cit.

120"...Igitur genitor noster Diue memorie Ordonius Rex, post depopoulatione harabum loci hujus Sancte ipse primus, ut fuerat exsuleo antico relictum han Sedem apprehendit cum villis, uel omnibus adjacenciiissuis...", A. FloRIANO, Diplomática española del período astur, 2 vol., Oviedo, 1949-1951, p. 270. Sobre este documento y el problema de la 'despoblación' y la 'repoblación' de la ciudad de Ourense: J.L. Quiroga, Du Miño au Douro, op. cit., pp. 338348.

${ }^{121}$ Como en las villae, entre otras, de Melgaço (Viana do Castelo, Fig. 10, no 373,), $914-$ 01-19: "...villares quem habemus de quondam parentorum nostrorum in monte quem vocitant Leporario...quem vocitan Messeganos...per suis terminis antiquis ..." (Tumbo de Celanova, 
mia $^{123}$. Las Fig. 9, 10, 11 y 12 nos muestran perfectamente ${ }^{124}$ la realidad de ese proceso reflejado a través de los documentos del Tumbo de Celanova, varias decenas de años posteriores a las pressuras ${ }^{125}$, y que hacen, precisamente, referencia a la 'restauración' y al 'reajuste'del poblamiento -de un poblamiento antiguo- sobre esas zonas: en los valles y al pie de los grandes sistemas montañosos. Esa imagen contrasta, como hemos señalado, con el poblamiento existente durante el siglo VIII y una buena parte del IX ${ }^{126}$, en esos grandes sistemas montañosos. Ello es lógico, puesto que se trata de dos tipos de poblamiento diferentes y que obedecen a causas y evoluciones también diferentes. El objetivo de este vasto proceso de 'reorganización' territorial, desde finales del s. IX y durante el X, es restaurar la organiza-

Libro $3^{\circ}$, fols. 165 v., 166 r.) (en lo sucesivo, TC); de Feá (Toén, Fig. 10, no 580), 942-0926: "...In ripa Minei villa Fegiocum...per antiquis termi-nos suos..." (TC, Libro $1^{\circ}$, fols. 2 v., 4 r.); de Albín (Santa Mariña de Macendo, Castrelo de Miño, Fig. 12, n⿳ 185), 989-12-20: "...villam nostram propiam qui vocitant Albarin quam habemus de parentorum et avorum ..." (TC, Libro $2^{\circ}$, Fol. 133 r).

${ }^{122}$ Como en las villae, entre otras, de Arnoya (Fig. 12, n ${ }^{\circ} 41$ ), 986-02-04: "...In ripa Minei, villa quaminquiunt Arnogia... quomodo ea comparavimus de homines presores de ipsas villas ..$"$ (TC, Libro $1^{\circ}$, fols. 33 v., 34 r.); de Cejo (Verea, Fig. 8 , $\mathrm{n}^{\circ}$ 608), 889-10-24: " ... in villa que vocitant Zegio, quos prenhendit ex antiquis..." (TC, Libro $2^{\circ}$, fols. 17 v., 18 r.); de Rabal (Celanova, Fig.11, $\mathrm{n}^{\circ}$ 207), 956-12-15: "...nostram hereditatem propiam quod habemus in villa qua dicunt Ravanale territorio Arnogie... per suis ter-minos antiquos..." (TC, Libro $2^{\circ}$, fols. 139 v., 140 r.).

${ }^{123}$ Como, por ejemplo, la villa de San Pedro de Laroá (Xinzo de Limia, Fig. 12, no 741), 909-05-07: "...ecclesia fundata manet, in finibus Galletie, territorio Limie...nos...filii et neptis fundatoris supradicti ecclesie...quod patrum nostrorum, de sulco antiquo adprehendere et construxerunt..." (TC, Libro $2^{\circ}$, fols. 103 r.-104 v.).

${ }^{124} \mathrm{Con}$ las restricciones hechas supra nota 116.

${ }^{125}$ Sobre la significación del término pressura, nos identificamos totalmente con la interpretación recientemente formulada por E. Portela y M.C. Pallarés para el conjunto de Galicia: "... En cualquier caso, la 'pressura' no reviste en Galicia el carácter pionero y fundacional que, desde el punto de vista de la ocupación del espacio, tuvo en las semidespobladas tierras de la meseta del Duero; es, más bien, el reajuste ocasionado por el asentamiento de un nuevo dominio político en territorios ya ocupados con anterioridad ...", E.PorTEla-M.C. PAllarÉs, Elementos para el análisis de la aristocracia altomedieval en Galicia: parentesco y patrimonio, "Studia Historica. Historia Medieval", V (1987), p. 28. Esta opinión (retomada por C. Baliñas en su Tesis doctoral: Do mito a realidade, op. cit.) concerniente al territorio de la actual Galicia (y a partir del análisis de la documentación de los monasterios de Sobrado y de Samos) es perfectamente aplicable al territorio entre el Miño y el Duero. La documentación del monasterio de Celanova y la contenida en el Portugalia Monumenta Historica, nos muestra que las pressuras se efectuan sobre tierras ya ocupadas desde antiguo y con el objetivo de restaurar los antiguos límites (terminos antiquos). Esto ha sido ya observado hace casi un siglo por A. Sampaio (As 'villas' do norte de Portugal, op. cit.) y muy recientemente por J. MATTOSO, Portugal no reino asturiano-leonés, op. cit.

${ }^{126} \mathrm{Y}$ que tiene su origen en el siglo VII, en lo que es una evolución lenta pero progresiva del poblamiento rural tardo-romano. 
ción y la jerarquización del poblamiento existente desde mediados del s. VI, así como 'reajustar' a los pressores en ese organigrama y sobre un espacio ya ocupado desde antiguo, en esas zonas de los grandes valles alrededor de los obispados y al pie de los grandes sistemas montañosos. Ello será efectuado, evidentemente, sobre nuevas bases, sobre todo en lo que respecta al ejercicio del poder y a la propiedad de las tierras 'conquistadas' ${ }^{\prime 27}$.

b) entre el 868 y el 880 , tiene lugar bajo el reinado de Alfonso III (866-911) la integración de las tierras situadas al sur del Limia y hasta el Duero. En este etapa, el protagonismo del monarca y de sus delegados es intenso ${ }^{128}$, lo que permite un avance y una conquista muy rápida y la instalación de la nueva 'frontera' sobre el Duero. Una vez integrado este vasto territorio, comienza el proceso de 'reorganización' territorial que instalará los polos de poder a partir de los cuales éste se va a efectuar:

- por una parte, a partir del eje Porto-Guimarães-Braga, el conde Vimara Peres (que efectua la 'toma' de Oporto en el 868$)^{129}$, y su hijo Lucido Vimaraz, van a 'reorganizar' administrativamente y a 'restaurar' la estructuración y jerarquizacióndel poblamiento antiguo. Así, a partir de la doble capital Oporto-Guimarães ${ }^{130}$, el conde Vimara Pérez pone en marcha ese proceso sobre los grandes valles que rodean estos dos polos de organización del espacio (pero también centros de poder y de la nueva organización político-administrativa) que eran Oporto y Guimarães. También, desde Braga, el hijo de Vimara Pérez (el conde Lucido Vimarani) va a llevar a cabo la misma tarea (desde finales del IX) en los grandes valles

\footnotetext{
${ }^{127} \mathrm{La}$ 'Reconquista', es decir, la conquista y la integración de esas zonas en el espacio político de la monarquía astur-leonesa; y la pressura, es decir, un proceso de cambio de manos en la propiedad de unas tierras 'abandonadas' (que sabemos estaban ocupadas de antiguo), proceso que la documentación muestra aparentemente como pacífico pero que ha debido de ser todo lo contrario.

${ }^{128} \mathrm{C}$. BALIÑAS, Do mito a realidade, op. cit.

129"...Era DCCCCVI prenditus est Portugale ad Vimarani Petri ..." (Cronica Labranense, "PMH, Script"., p. 240).

${ }^{130}$ Doble capital por razones evidentes de estrategia militar, ya que la ciudad de Oporto era fácilmente vulnerable por la costa (ello a pesar del imponente sitio sobre el que se sitúa la catedral y la fortificación que la rodeaba desde época sueva: J. L. QUIROGA, Du Miño au Douro, op. cit., pp. 352-356) en una época en la que las razzias normandas van a ser constantes. Por ello, Guimarães (que ha sido también atacada por los Normandos), situada en el interior, era más fácilmente defendible, especialmente tras el proceso de fortificación efectuado por orden de la condesa Mumadona. No olvidemos, por otra parte, que dicha condesa estaba emparentada por matrimonio, con un miembro de la dinastía condal portuense. J. MATtOSO, Portugal no reino asturiano-leonês, op. cit.
} 
que rodean la ciudad episcopal de Braga (y antigua capital del conventus bracarensis), entre los ríos Limia y Ave (el que será su territorio diocesano).

La serie de mapas referentes a la repartición de las villae (Figs. 8 a 12), nos muestran las zonas que serán el escenario de ese vasto proceso de 'reorganización' territorial desde el 868 y durante todo el s. X:

- los grandes valles alrededor de Braga (entre el Limia y el Câvado), como, por ejemplo, en Negreiros (Barcelos, Fig. 8, $\left.\mathrm{n}^{0} 79\right)^{131}$, en Lamaçães (Braga, Fig. 8, $\left.\mathrm{n}^{0} 120\right)^{132}$, en Figueiredo (Guimarães, Fig. 9, $\mathrm{n}^{0}$ 275) $)^{133}$, en Oleiros (Guimarães, Fig. 9, $\mathrm{n}^{0}$ 284) ) $^{134}$, en Aguas Santas (Povoa de Lanhoso, Fig. 9, $\left.\mathrm{n}^{0} 534\right)^{135}$, en San Salvador de Vitorino das Donas (Ponte do Lima, Fig. 9, $\mathrm{n}^{0}$ 525) ${ }^{136}$, en Santa Eulalia de Rio Covo (Barcelos, Fig. 10, $\left.\mathrm{n}^{\mathrm{o}} 83\right)^{137}$, en Povoa de Varzim (Fig. 11, $\mathrm{n}^{\mathrm{o}}$ $540)^{138}$, etc.

- alrededor de Guimarães, en los valles situados entre los ríos Ave y Vizela ${ }^{139}$, como, por ejemplo, en Paraiso (Infias, Guimarães, Fig. 8, ${ }^{0}$

\footnotetext{
${ }^{131}$ Una de las primeras menciones referentes a nuestro espacio y, por otra parte, documento de 'lecturas' e interpretaciones diferentes. 870: "...baselica sita et fundata est in villa negrelus territorio bracharense urbium portugalensis secum sancte marie subtus mons cavalus prope rivulum ave ... edificavimus istius domun in nostra villa que presimus cum cornam el albende Adefonsus principem et comite Lucidii vimarani..." ("PMH, DC", $n^{\circ}$ 5). Para Sánchez Albornoz, estamos ante una prueba palmaria del 'desierto', para otros investigadores (A. de Jesus da Costa, J. Mattoso, etc.) se trata de una prueba evidente de la existencia de población...

132904: "... in villa Nugaria inter Desideria et Lamazales..." (Liber Fidei, $n^{\circ} 175$ ) (en lo sucesivo, LF).

133924: "...in terminos de Figaretum ..." ("PMH, DC, $n^{\circ} 29$ ).

${ }^{134} 924:$ : ...Belisarius presbiter tibi Gundisindus presbiter...de ecclesia mea propia vocabulo Sancti Michaelis Archangeli que est fundata in villa que vocitant Palatiolo monte Sancta Marta prope rivulo Ave ..." (PMH, DC, $\left.n^{\circ} 29\right)$.

$135 "$ "..comtemptio inter partem domni nausti colimbriensis sedis episcopi et domni sisnandi hiriensis sedis episcopi pro ecclesia et villa vocabulo sancta eolalia quez scita est in silva scura in territorio brakalensis sedis ubi dicent aquas sanctas quot prehendiderunt homines domni nausti episcopi..." ("PMH, DC", n 13)

136915: " ...villas et ecclesias cum villa videlicet et ecclesias que sunt inter Catavo et Lima id est Crespellus et Vulturinus ..." (LF, $\left.n^{\circ} 429\right)$.

137949: "...cartula de medietatem de omne mea hereditate que habeo in sancta eolalia de omnia quos obtinuit cum mea muliere gredo extra..." ("PMH, DC", n 59 ).

138953: "...quomodo dividet cum villa fromarici et cum villa auracini et inde per aqua maris usque in suos terminos antiquos..." ("PMH, DC", $\mathrm{n}^{\circ} 67$ ).

${ }^{139}$ Lo que es el territorio medieval (ya desde el siglo X) de Inter Ambas Aves.
} 
278), en São João Baptista de Pencelo (Guimarães, Fig. $\left.9, \mathrm{n}^{0} 286\right)^{140}$, en São João da Ponte (Guimarães, Fig. 9, n $\left.^{\circ} 288\right)^{141}$, en Creixomil Guimarães, Fig. 10, $\left.\mathrm{n}^{0} 273\right)^{142}$, etc.

- los valles de los ríos situados en torno a Oporto ${ }^{143}$, como son los de los ríos Leza, Ferreira, Sousa, Tâmega y, por supuesto, el Duero (Fig. 1). Podemos citar, entre otras, las villae de Gondomar (São Cosme, Fig. 8, $\left.\mathrm{n}^{\mathrm{o}} 261\right)^{144}$, de Soalhães (Marco de Canaveses, Fig. 8, $\left.\mathrm{n}^{\mathrm{o}} 350\right)^{145}$, de Lordosa (Ras, Penafiel, Fig. 8, $\left.\mathrm{n}^{\mathrm{0}} 482\right)^{146}$, de Esposende (Foz de Sousa, Gondomar, Fig. 9, $\left.\mathrm{n}^{\mathrm{o}} 256\right)^{147}$, de Eja (Penafiel, Fig. 10, $\left.\mathrm{n}^{\mathrm{o}} 473\right)^{148}$, de

${ }^{140} 908$ : "...ecclesiam Sancti Johannis...cum omne utensilia sue...fundata in villa que vocitatur Pensello..." ("HSC", $n^{\circ} 28$ ). $\mathrm{n}^{\circ} 30$ )

141911: "...ecclesiam Sancti Johannis in Ripa Ave cum sua villa et adjacencia..." ("HSC",

142926: "...villa nominata Crexemir que est secus fontano Selio, territorio inter Ambas Aves ..." ("PMH, DC", no 31).

${ }^{143}$ Proceso de 'reorganización' y de 'restauración' del poblamiento antiguo, que durante finales del IX y todo el siglo $X$ tiene como límite el gran sistema montañoso de la Serra do Marão. Vemos siempre, al comienzo de este proceso, cómo el límite de la 'colonización' de las tierras desde finales del IX y durante todo el s. X, son los grandes sistemas montañosos, sobre los que existe otra organización (desde el siglo VII) y otro tipo de poblamiento que no se corresponde con el que los documentos nos muestran en ese momento.

144897: "...et de alia villa III minus III sicut venit ad filia mea Froilo in porcione per suos terminos et ecclesia de Sancta Eolalia de Gondomar integra ..." ("PMH, DC", $\mathrm{n}^{\circ} 12$ ). Se trata de una de las primeras villas y ecclesias mencionadas en la documentación para esta zona alrededor de Oporto.

145877: "...et quorum baselica Santi Martini Episcopi, que est fundata in villa de Suylanas..." ("PMH, DC", n 8).

146882: "...baselica fundamus in villa quod vocitant lauridosa inter duas annes kavuluno et cebrario subtos monte petroselo territorio anegie ... pro ubi illa obtinuimus de presuria pro suis locis et terminus antiquis ..." ("PMH, DC", $\mathrm{n}^{\circ}$ 9). Solamente 14 años después de la 'toma' de Oporto por el conde Vimara Pérez, tenemos una pressura que se refiere a los terminos antiquos... ¿antes del 868? Evidentemente, se trata de los límites del antiguo lugar que ahora se van a 'reajustar' a la nueva organización espacial de la villa con la fijación del hábitat y del centro de culto, como células básicas de la organización del espacio.

147922: "... quomodo dividit cum sposati et item trauxivit dorium in villa palatiolo et concludit ipsam villam totam exceptis illa Villa que est de aliso heredes de levari..." ("PHM, DC", $\mathrm{n}^{\circ} 25$ ).

148922: "...in ripa de ipso dorio a porto civitatis anegia ecclesiam sancte marine cum suos dextros inte-gros vel debito ubi tamica intrat in dorio ad integra..." ("PMH, DC", $\left.n^{\circ} 25\right)$. Una de las 'ciudades' afectadas por las razzias de Alfonso I a mediados del s. VIII y que, según Sánchez Albornoz, habría desaparecido para siempre. La Arqueología y los textos prueban lo contrario: C.A. FERREIRA DE AlMEIDA-F.G. ALMEIDA LOPES, Eja (Entre-os-Rios). A Civitas e a Igreja de S.Miguel, "Portugalia", II-III (1981-1982), pp. 131 y ss. 
Lavra (Matosinhos, Fig. 10, $\left.\mathrm{n}^{\mathrm{o}} 366\right)^{149}$, de Luzim (Penafiel, Fig. 10, $\mathrm{n}^{\mathrm{o}}$ 473) ${ }^{150}$, de Aldoar (Porto, Fig. 10, $\mathrm{n}^{0}$ 527) ${ }^{151}$, de Varzea do Douro (M. de Canaveses, Fig. 11, $\left.\mathrm{n}^{0} 360\right)^{152}$, de Custoias (Matosinhos, Fig. 11, $\mathrm{n}^{0}$ $364)^{153}$, de Guilhabreu (Vila do Conde, Fig. 12, $\left.\mathrm{n}^{\mathrm{o}} 655\right)^{154}$.

-por otra parte, a partir del alto valle del Támega (en torno al eje Chaves-Verín) y de la meseta de la Limia, el conde Odoario procederá a la integración y a la reorganización de ese espacio. Hacia el 872 'toma' la ciudad de Chaves (la antigua Aquae Flaviae) con los territorios que la rodean, como sabemos por un documento del Tumbo de Celanova del 1 de Octubre del 982: "...Cultorum etenim manet cognitum et plerisque notissimun hoc quod data es terra ad populandum illustrisimo viro domno Odoario digno bellatori in era D CCCC X a principe serenissimi domno Adefonso, qui venit in civitatem Flavias secus fluvius Tamice, vicos et castella erexit et civitates munivit et villas populavit atque eas certis limitibus firmavit et terminis certis locavit et inter utrosque abitantes divisit et omnia ordinate atque firmate benecuncta disposuit ..."155. Esta frase, muestra con claridad los objetivos de este vasto proceso de 'reorganización' territorial que la monarquía asturleonesa va a efectuar a través de sus delegados (condes y ciertos monasterios) desde finales del IX y durante todo el $\mathrm{s}$. $\mathrm{X}$, en el espacio entre el Miño y el Duero:

\footnotetext{
149897: "...etiam simul et mea de monasterio de labra qui est fundato ab antiquo in ripa maris comodo est conclusa de aqua in aqua et de karia antiqua usque in mare...". 29 años después de la 'toma' de Oporto, en el 868, ¿ha pasado tiempo suficiente para decir que este monasterio (en la villa de Lavra) es fundato ab antiquo? jIncluso una lectura 'literal' de este documento, no permite decir que este lugar estaba 'despoblado' antes del 868 !

150943: "...ecclesia mea propia vocabulo sancto iohanne quorum baselica fundata est subtus mons petroselo discurrente ribulo tamica in villa quos vocitant losidi in loco predicto in casale quos fuit de patre meo prudenzo quos edificavi de verede damus vobis..." (PMH, DC, $\mathrm{n}^{\circ}$ 53).

151944: "...ecclesiam vocabulo sancti martini episcopi et sancti michaeli archangeli in villa que vocitant alduarii fluvio dorio territorio portugalensis subtus castro mafamudi et fuit ista hereditate de pater meo zaragauti congnomento..." ("PMH, DC", $\mathrm{n}^{\circ} 54$ ).

152964: "...scritura venditionis sigudi et facio de ereditate mea probia que aveo de parte de meos avios nominibis leoveredo et auremiga in villa de sancto martino terridorio anegie inter duriu et tamiga vindo vobis ipsa villa omnia..." ("PMH, DC", $n^{\circ} 54$ ).

${ }^{153} 967:$ " ...in villa quo vocitant custodias iusta ribulo leza territorio portugalensis vendimus vobis ipsa hereditate...per omnes illorum antiquores terminum ..." ("PMH, DC", n 93).

154976: "...erdade nostra propia que habemus in villa viliaveredi...per suis locis et vicis et terminis antiquis et quanto in ipsa erdade aprestitu ominis est aveatis et posteritas... ("PMH, $\mathrm{DC}^{\prime \prime}, \mathrm{n}^{\mathrm{0}} 73$ ).

${ }^{155} \mathrm{TC}$, Libro $2^{\circ}$, fols. 97 v. $-100 \mathrm{v}$.
} 
- "...data est terra ad populandum illustrisimo viro domno Odoario...", es decir, que el rey delega al conde Odoario el poder para 'conquistar' e integrar ese espacio (el alto valle del Támega y la meseta limiana) en la órbita de la monarquía astur-leonesa.

- " ...qui venit in civitatem Flavias secus flumine Tamice ...", es decir, que el conde Odoario instalará en la ciudad de Chaves la sede de un amplio condado (del que se va a desmembrar poco tiempo después el territorium limie, otro condado) y la fortificará con una nueva muralla.

- " ...vicos et castella erexit et civitates munivit et villas populavit...", de nuevo encontramos la jerarquización y la estructuración del poblamiento típicamente romana: a comienzos del $\mathrm{s}$. V, como nos informa el Ier Concilio de Toledo del $400^{156}$, en la segunda mitad del s. VI, como nos informa el Parroquial Suevo ${ }^{157}$, a finales del s. VII, en Isidoro de Sevilla ${ }^{158}$, a mediados del s. VIII en la Crónica de Alfonso III ${ }^{159} \mathrm{y}$, finalmente, en el documento del Tumbo de Celanova que venimos comentando (y que hace referencia a hechos acontecidos hacia el 872). Ello confirma el proceso de 'restauración' del poblamiento antiguo, sobre bases nuevas (las del poder, las de otra realidad socio-económica, las de otra organización del espacio de la villa), en el marco de este vasto proceso de 'reorganización' territorial que se denomina 'Reconquista' y 'Repoblación'. La civitas, será la sede del poder (condal o episcopal: Chaves, Ourense, Braga, Porto, Guimarães ...); a veces, la civitas, es también un lugar fortificado al mismo tiempo que sede del poder encargado de un territorium (como es el caso de la civitas anegia $)^{160}$. Los castella, serán lugares de control del territorio

156" ...si intra civitate fuerint vel in loco in quo est ecclesia aut castelli aut vicus aut villae...", J. VIVES, Concilios visigóticos e hispano-romanos, Madrid-Barcelona, 1963, p. 21.

${ }^{157}$ En ese importante documento se mencionan civitas, castella, castra, vicus y villae: $\mathrm{P}$. DAvid, Etudes historiques, op. cit.; L.A. GARCía MoRENO, 'Civitates' et ' castella' durante la época suevo-gótica en el NO de las Españas, "Los origenes de la ciudad en el noroeste hispánico", op. cit.

158"..vicum, castellum, pagus...", citado por L.A. GARCía MORENO, Historia de España visigoda, Madrid, 1989.

159" ...multas civitates bellando cepit...seu castra, cum villis et viculis suis...", Y. BONNAZ, Chroniques Asturiennes. Fin IX' siècle, París, 1987, p. 45.

${ }^{160} \mathrm{El}$ emplazamiento de la civitas Anegia en la desembocadadura del Támega en el Duero subraya el papel estratégico de esta civitas, que poseía además un territorio con varias fortificaciones para asegurar su defensa. La civitas Anegia, representa perfectamente el modelo de un lugar fortificado principal y otros secundarios con funciones estrictamente militares en el interior de un territorium más amplio (en este caso, el de Oporto): M. BARROCA, Do castelo da Reconquista ao Castelo Românico (ss. IX a XII), "Portugalia", XI-XII (1990-1991), pp. 92- 
por excelencia - se trate de torres, de castillos o de motas- ${ }^{161}$ y el símbolo del ejercicio del poder sobre los hombres y el espacio ${ }^{162}$. Los vicos y villae formarán parte de esa célula básica de organización espacial que es la aldea, en un proceso progresivo de concentración del hábitat, lo que no impide la dispersión de los lugares de habitación en el interior de la villa ${ }^{163}$.

- certis limitibus firmavit et terminis certis locavit et inter utrosque abitantes divisit, es decir, que con la ayuda de los habitantes que allí estaban (y que siempre estuvieron), los delegados del rey van a 'restaurar' los límites de los antiguos núcleos de poblamiento y a proceder al 'reajuste' que la llegada de los pressores va a provocar en la organización espacial y en la propiedad de las tierras. Es decir, en la organización social del espacio ${ }^{164}$. Los mapas de repartición de las villae (Figs. 8 a 12), nos muestran con claridad $^{165}$, las zonas que, en la parte interior del antiguo conventus

93 (pp. 89-136).

${ }^{161}$ Que en la Península Ibérica ha habido motas es un hecho ya incuestionable. Ello ha sido demostrado por J.A. GUTIÉRREZ GONZÁLEZ, Fortificaciones y feudalismo, op. cit., pp. 30-40. Las motas están tambiénpresentes en el paisaje del noroeste peninsular. Por supuesto, mucho menos numerosas que en la Meseta, ya que en el noroeste la geografía, dominantemente montañosa, no favorece la realización de este tipo de fortificaciones terreras; sí, por el contrario, las Torres y los denominados 'nidos de águila'. Una introducción al problema de 'hábitat fortificado' en el noroeste en: J. LOPEZ QUIROGA, Du Miño au Douro, op. cit., pp. 737-766; M. Rodríguez Lovelle, Du Golfe Cantabrique au Miño, op. cit.

${ }^{162} \mathrm{~A}$. Bazzana ha insistido, con frecuencia, en la relación entre las fortificaciones y la evolución y la distribución del poblamiento. Incluso ha considerado el papel militar como secundario: "...je donnerais plutôt la priorité, quand il s'agit de tenter d'expliquer la présence d'un site castral, aux nécessités du peuplement: mise en place des populations, détermination des territoires mais aussi des terroirs nourriciers...", "...Raisonner uniquement en termes de 'systèmes de défense', de 'réseau castral' integré, donc de stratégies des appareils d'État conduit parfois l' historien à une déformation volontaire du 'paysage' historico-archéologique et des données de la documentation...", A. BAZZANA, Maisons d'Al-Andalus. Habitat médiéval et structures de peuplement dans l'Espagne orientale (Collection de la Casa de Velázquez, 37), Madrid, 1992, p. 264 y 266-267. Sobre la función de las fortificaciones en la evolución del poblamiento es capital la tesis de A. Debord sobre la Charente, un verdadero modelo de integración de fuentes escritas y arqueológicas con el objetivo de construir un discurso histórico coherente: A. DEBORD, La société laïque dans les pays de la Charente, $X^{e}$-XIII siècles, París, 1984. También: A. DEBORD, Château et résidence aristocratique. Reflexions pour la recherche, "Château-Gaillard" (Études de Castellologie Médiévale), Caen, 1986, pp. 41-51.

${ }^{163}$ M.C. Pallarés-E. Portela, Galicia na época medieval, op. cit., p. 67.

${ }^{164}$ J.A. GARCía DE CORTÁZAR, Del Cantábrico al Duero, op. cit.; IDEM, Las formas de organización social del espacio del valle del Duero, op. cit.

${ }^{165}$ Siempre teniendo en cuenta las restricciones efectuadas supra nota 115. 
bracarensis, han sido objeto prioritario ${ }^{166}$ desde finales del IX del proceso que estamos describiendo: el alto valle del Támega (alrededor de Chaves y Verín) $^{167}$ y la meseta de la Limia (alrededor de Laroá) ${ }^{168}$.

En definitiva, este vasto proceso que comienza desde finales del s. IX (en lo que respecta al territorio entre el Miño y el Duero) y que continua durante todo el s. X (y posteriormente, por supuesto), se efectua sobre los espacios que estaban mejor organizados y mas desarrollados en el siglo VI como nos muestra el Parroquial Suevo, desde el punto de vista de la organización y de la estructuración típicamente romana del poblamiento. Es decir, las zonas situadas alrededor de las antiguas ciudades episcopales, a lo largo de los valles que las rodean y próximas pero en el límite de los

\footnotetext{
${ }^{166}$ Puesto que, como hemos visto, una gran parte del territorio del Miño al Duero (las zonas en relación con los grandes sistemas montañosos) va a permanecer al margen (al menos al comienzo) del proceso de 'reorganización' territorial efectuado por la monarquía astur-leonesa desde finales del s. IX. En esas zonas (Fig. 4) encontramos un poblamiento marginal desde el siglo VII, que será dominante durante el VIII y la mayor parte del IX, y de nuevo quedará como marginal desde finales del IX y durante el s. X como consecuencia, precisamente de ese proceso.

${ }^{167}$ Como, por ejemplo, en Bustelo (Santa María de Villardevós, Fig. 10, n 729 -), 931-0911: "...facimus textum scripture contramutationis de nostra villa qui iacet in Baroncelli, rivulo Tamega, villa que vocitant Berini, que habemus de avio nostro domno Odoario, et dividet ipsa villa quam illa de Sancto Felice, et qum villa Keizanes, et qum villa de Avetes, et inde in Bustello...per suis terminos antiquos..." (TC, Libro $3^{\circ}$, fol. 159r) ; en Lamas (Santa Eulalia de Montes, Cualedro, Fig. 11, $\mathrm{n}^{\circ}$ 227), 950-06-13: " ...et descendentes peripsum aggerem ad rivulum qui de Lamas ad Balderici discurret..." (TC, Libro $1^{\circ}$, fols. 37 v.-38 r.); de Oimbra (Fig. 11, no 429), 953-12-23: " ...et de medietate de vineas quas comparavimus in Olimbria.... illas vineas sunt in villa quam vocitant Olimbria, territorio Baroncelli prope rivulo Tamega..." (TC, Libro $2^{\circ}$, fol. 47 r.); de Verín (Fig. 11, $n^{\circ}$ 619), 950-06-13: " ...est ipsam predictam villam Baroncelli...cum aliis adiacentis ad ipsam villam Baroncelli ..." (TC, Libro $1^{\circ}$, fols. 37 v. -38 r.).

${ }^{168}$ Como, por ejemplo, en Filgueira (San Salvador de Sabucedo, Porquera, Fig. 11, $n^{0} 526$ ), 995-07-19: "...villa de Felgaria integra avui nostri Gunterici et concessit eam filie sue genitrice nostri ..." (TC, Libro $3^{\circ}$, fol. 175 r.); de Codosedo (Sarreaus, Fig. 11, ${ }^{\circ} 570$-), 950-08-25: "...in caput Limie villare et Codeseta cum suis adiunctionibus quod nos competet ..." (TC Libro $1^{\circ}$, fols. 8 r. -8 v.); de Sarreaus (Fig. 11, $n^{\circ}$ 574), 962-06-11: "...Alias villas, in Limia quam dicunt Sarrianos prope domun Sanctae Marie de Hordines,quantum genitoris nostri habuerunt quam etiam illos et nos de comparato enimus..." (TC, Libro $1^{\circ}$, fols. 9 r. -9 v.); de Trasmiras (Fig. 11, $\mathrm{n}^{\circ}$ 601), 969-08-07: "...Quarta villa Trasmiri quinta integra cum omnibus adiun-tionibus ..." (TC, Libro $2^{\circ}$, fols. 88 r. -88 v.); de Paredes (Laroá, Xinzo de Limia, Fig. $\left.11, \mathrm{n}^{\circ} 740\right), 978-10-23$ : "...Concedo atque offero Deo eterno et vobis ipsam iamdictam villam Parietes, per omnes hos terminos et suos antiquos limites ..." (TC, Libro $3^{\circ}$, fol. $168 \mathrm{r}$ ).
} 
grandes sistemas montañosos ${ }^{169}$. Como nos muestran los mapas de repartición de las villae (Figs. 8 a 12), la 'restauración' del poblamiento antiguo es hecha alrededor del antiguo eje Ourense-Braga-Oporto y de su importante red viaria. A estos tres polos de organización espacial, se añadirán ahora otros que son fruto de la nueva situación socio-política: por una parte, en el eje de ciudades episcopales se van a integrar el monasterio de Celanova y el monasterio-fortaleza de Guimarães (éste dará lugar desde finales del X y, sobre todo, en el curso del XI a un importante burgo con características urbanas); por otra parte, se 'recuperará' el papel de Chaves como polo organizador y estructurante en el alto valle del Támega. Antes de bien avanzado el s. XI (en muchos casos a partir del XII, en otros nunca) las zonas montañosas (donde se situa ese poblamiento dominante durante el VIII y la mayor parte del s. IX y que ahora será de nuevo 'marginal' en relación a la organización y estructuración del poblamiento que tiene lugar desde finales del s. IX y durante todo el $\mathrm{X}$ ), no se verán afectadas por este proceso. Ello no hace sino confirmar la existencia de otro tipo de poblamiento que no es mencionado en los textos, pero que la arqueología sí permite observar (Fig. 4). El contraste entre los dos tipos de información (textos y arqueología), en lo que a la distribución del poblamiento se refiere, es claramente visible cuando ponemos en relación ambas informaciones en un espacio más reducido que el territorio entre el Miño y el Duero. Por ejemplo, en el alto valle del Támega (Fig. 13), podemos observar ese contraste de información que no es contradictoria, ni mucho menos, sino complementaria y que permite trazar una historia del poblamiento que corrige las distorsiones producidas por la utilización exlusiva de las fuentes documentales.

\subsection{La 'reorganización' de la antigua red eclesiástica rural.}

Se trata, en efecto, de la otra característica del proceso de 'reorganización'territorial entre el Miño y el Duero: la 'restauración' de las antiguas iglesias (según los textos 'en ruinas') y de la antigua red eclesiástica, con la

\footnotetext{
${ }^{169}$ Son los espacios donde cristalizará la organización que denominamos feudal. Para la parte costera de nuestro territorio, los grandes valles que rodean Braga y Oporto (el Entre-Douro-eMinho), ha sido constatado por J. MATTOSO, Portugal no reino asturiano-leonês, op. cit. Para el interior del territorio entre el Miño y el Duero, espacios donde cristalizará el feudalimo son: los valles que rodean Ourense (el curso medio del Miño y del Arnoya), la meseta limiana y el alto valle del Támega (alrededor del eje Verín-Chaves).
} 
reinstalación de las élites eclesiásticas en el medio rural. Los textos (Figs. 2,3 y 7) y, sobre todo, la arqueología (Figs. 5 y 6 ) nos informan sobre ese doble proceso. A partir de las antiguas ciudades episcopales (del eje Ourense-Braga-Oporto) y de importantes centros monásticos (como Celanova o Guimarães), se va a proceder a la 'restauración' de antiguas iglesias y, a veces, a la construcción de otras nuevas. Como con las villae, estamos en presencia del mismo fenómeno de 'restauración' del poblamiento antiguo sobre las mismas zonas de los grandes valles que rodean a los obispados e importantes centros monásticos. Es la 'continuación' del proceso de jerarquización y de estructuración de la red eclesiástica rural comenzado a mediados del s. VI, sobre las mismas zonas pero con otros protagonistas. La topografía religiosa y la topografía funeraria rurales nos muestran claramente dónde y cómo se va efectuar ese proceso de 'reinstalación' de las élites eclesiásticas rurales.

Así, en lo que respecta a la topografía religiosa, la Fig. 5 nos permite diferenciar perfectamente los dos polos principales a partir de los cuales se va proceder a la'reorganización' de la red eclesiástica rural desde finales del IX y durante todo el s. X:

-el obispado de Ourense $e^{170}$, polo a partir del cual se van a 'reorganizar' las zonas de los valles del curso medio del Miño ${ }^{171}$, del tramo final del $\operatorname{Sil}^{172}$ y a lo largo del curso del Arnoya ${ }^{173}$. Entre los

\footnotetext{
${ }^{170}$ Puesto que el papel de Chaves en el proceso de 'restauración' de la antigua red eclesiástica rural es inexistente. Ello es lógico, ya que este proceso es efectuado a partir de los obispados y Chaves ya no lo es desde finales del s. V. Su papel, sin embargo, es fundamental desde el punto de vista socio-político, en la 'restauración' del poblamiento antiguo en el alto valle del Támega (Fig. 13), por lo tanto, en la organización social del espacio, como hemos visto en el epígrafe precedente.

${ }^{171}$ Como, por ejemplo, la capilla de Santa Eugenia (San Lorenzo de Piñor, Barbadanes, Fig. $5, n^{\circ} 66$ ), la capilla de San Lorenzo (San Miguel de Meliás, Coles, Fig. $5, n^{\circ} 221$ ), en Seixalbo (Ourense, Fig. 5, no 347), en San Mamed de Coto d'Astrés (Vilar, Ourense, Fig. 5, n⿳ 440).

${ }^{172}$ Como, por ejemplo, en San Juan de Camba (Castro Caldelas, Fig. 5, 190), en Alais (C. Caldelas, Fig. 5, $\mathrm{n}^{\circ} 188$ ), en San Pedro de Rocas (Esgos, Fig. $5, \mathrm{n}^{\circ} 236$ ), en la capilla de San Juan do Cachón (San Esteban de Ribas del Sil, Nogueira de Ramuín, Fig. 5, $\mathrm{n}^{\circ} 425$ ), en la capilla de Canal (San Esteban de Ribas del Sil, Nogueira de Ramuín, Fig. $5, n^{\circ} 426$ ), en Sacardebois (Parada del Sil, Fig. 5, n⿳4 450).

${ }^{173}$ Como en San Martín de Pazó (Allariz, Fig. 5, n⿳0 4), en Sua Torre de Ambía (San Esteban de Ambía, Baños de Molgas, Fig. 5, n⿳ 63), en Santa Eufemia de Ambía (Baños de Molgas, Fig. 5, $n^{\circ}$ 64), en San Salvador de Baños de Molgas (Fig. 5, $n^{\circ} 65$ ), en Santa Eulalia de Berredo (A Bola, Fig. 5, $\mathrm{n}^{\circ}$ 96), en la capilla de San Cibrán (Pardavedra, A Bola, Fig. 5 , $n^{\circ}$ 98), en la capilla de San Miguel de Celanova (Celanova, Fig. 5, $n^{\circ} 203$ ), en Santa Mariña de Vilanova das Infantas (Celanova, Fig. 5, $\mathrm{n}^{\circ} 206$ ).
} 
rasgos distintivos de este proceso debemos subrayar la importancia del elemento mozárabe, que está presente en la propia fisonomía de estos edificios de culto (Fig. 6) ${ }^{174}$, pero también en los protagonistas (como el obispo Sebastián de Ourense, un mozárabe y probable autor de la versión erudita de la Crónica de Alfonso III) ${ }^{175}$. La capilla de San Miguel de Celanova (Fig. 6, $\mathrm{n}^{\circ}$ 203), constituye un ejemplo paradigmático del papel de lo mozárabe en el proceso que venimos describiendo y de su vinculación a la organización eclesiástica que se está 'reinstaurando'. Esta organización religiosa, es la 'continuación' de aquella que había comenzado con San Martín de Dumio desde mediados del s. VI y sobre las mismas zonas. Cuando se intenta aplicar esta estructuración sobre aquellas zonas que habían quedado al 'margen' del proceso ${ }^{176}$, podemos ver perfectamente cómo se intenta vincular la organización existente a la que había comenzado a implantarse desde mediados del s. VI. El monasterio de San Pedro de Rocas (Fig. 5, $\mathrm{n}^{\circ}$ 236) es también, en este sentido, un ejemplo paradigmático. En este lugar había comenzado a desarrollarse desde el siglo VII una comunidad mixta con una organización religiosa y un tipo de hábitat en un paisaje típicamente fructuosiano. Durante todo el VIII y el siglo IX esta organización continuará desarrollándose. Sin embargo, en el siglo $\mathrm{X}$ tenemos elementos que nos informan de la 'voluntad' de cambiar esta tradición y esta organización existente. En primer lugar, el texto de 'restauración' del monasterio en el siglo $\mathrm{X}$ hace alusión, en una larga introducción, a los orígenes 'eremíticos' del lugar ${ }^{177}$, lo que viene a 'coincidir' con el texto

${ }^{174}$ Como, por ejemplo, en San Martín de Pazó (Allariz, Fig. 6, no 4), en Santa Eufemia de Ambía (Baños de Molgas, Fig. 6, $n^{\circ}$ 64), en Santa Eulalia de Berredo (A Bola, Fig. 6, $n^{\circ}$ 96), en la capilla de San Cibrán (Pardavedra, Fig. 6, $n^{\circ}$ 98), en San Juan de Camba (Castro Caldelas, Fig. 6, $n^{\circ} 190$ ), en Alais (C.Caldelas, Fig. 6, $n^{\circ} 188$ ), en la capilla de San Miguel de Celanova (Celanova, Fig. 6, $n^{\circ}$ 203), en Santa Mariña de Vilanova das Infantas (Celanova, Fig. 6, $n^{\circ}$ 206), en la capilla de San Lorenzo (San Miguel de Meliás, Coles, Fig. 6, n² 221), en la capilla de Canal (San Esteban de Ribas del Sil, N.de Ramuín, Fig. 6, n⿳ ${ }^{\circ} 46$ ), en Seixalbo (Ourense, Fig. 6, $\mathrm{n}^{\circ}$ 437), en Arcos (Villamartín de Valdeorras, Fig. 6, $\mathrm{n}^{\circ} 727$ ), en Bembibre (Viana del Bollo, Fig. 6, $\mathrm{n}^{\circ}$ 622), en Viana del Bollo (Fig. 6, $\mathrm{n}^{\circ}$ 623), en Santa María de Mixós (San Mamede de Estevesiños, Monterrei, Fig. 6, n 411).

${ }^{175}$ Y Bonnaz, Chroniques Asturiennes, op. cit.

${ }^{176}$ Las que muestran una organización 'menos desarrollada' o organizadas de forma diferente, como la parte interior montañosa del territorio entre el Miño y el Duero. Ello se observa perfectamente en el Parroquial Suevo: P. DAvid, Études historiques, op. cit.

${ }^{177}$ E DURo PEÑa, El monasterio de San Pedro de Rocas y su colección documental, Ourense, Instituto de Estudios Orensanos 'Padre Feijóo', 1972. 
de la inscripción de 'fundación' del monasterio en el s. VI ${ }^{178}$. En segundo lugar, el pie de altar de tipo mozárabe ${ }^{179}$, por lo tanto del s. X, que no deja lugar a la duda en lo que respecta al contexto en el que se debe de situar este monasterio. Puesto que, efectivamene, en San Pedro de Rocas estamos ante un intento de querer remontar el orígen del lugar y de la organización religiosa allí existente a un monaquismo bien diferente al típicamente fructuosiano. Lógicamente, el documento de 'fundación' no puede hacer referencia a una comunidad mixta ${ }^{180}$, sino a los orígenes 'eremíticos' y a una estricta organización religiosa.En este contexto ${ }^{181}$ hay que situar la elaboración, probablemente en el siglo $\mathrm{X}$, del epígrafe considerado del siglo VI. Así, el documento de 'restauración', la inscripción 'fundacional' y el pie de altar mozárabe, deben ser situados en el mismo contexto y en ese intento de restaurar una organización religiosa que había comenzado a estructurarse a mediados del siglo VI y que fue bruscamente interrumpido a principios y mediados del siglo VIII. Este proceso de 'reorganización' de la antigua red eclesiástica desde finales del siglo IX y durante todo el $\mathrm{X}$, va a suponer una cierta 'ruptura' respecto al tipo de organización religiosa existente desde mediados del VII y hasta mediados del IX. O dicho de otra forma: lo que surgió como 'marginal' se convierte de nuevo en 'marginal' tras haber sido durante dos siglos 'dominante'. Como en San Pedro de Rocas, otros lugares del curso medio del Miño y del tramo final del Sil (la denominada Ribera Sagrada), van a sufrir un proceso similar de adaptación a la nueva organización eclesiástica que se está instalando ${ }^{182}$. -alrededor del obispado de Braga ${ }^{183}$, del monasterio-fortaleza de

\footnotetext{
${ }^{178} \mathrm{M}$. NÚÑEZ RodRíGUEZ, Inscripciones de la Galicia Altomedieval, "Revista de Guimarães", LXXXIX (1979), pp. 293-321. 51 .

${ }^{179}$ M. NÚÑ̃EZ RodríGUEZ, Arquitectura pre-románica en Galicia, A Coruña, 1978, pp. 47 -

${ }^{180}$ En la que los niños están presentes, como lo prueban las tumbas de recién nacidos halladas en las excavaciones arqueológicas allí efectuadas: L. ORERO GRANDAL, San Pedro de Rocas (Esgos, Ourense),"Arqueoloxía/Informes. Campaña 1988", Santiago de Compostela, 1988-1991, pp. 215-218.

${ }^{181}$ No es una simple coincidencia que haya un documento y un epígrafe que hagan referencia a los orígenes 'eremíticos' del lugar. Sil.

${ }^{182}$ Como los monasterios de Santa Cristina de Ribas del Sil y de San Esteban de Ribas del

${ }^{183}$ Como, por ejemplo, en Feira Nova (Santa Marina de Ferreiros, Amares, Fig. 5, $\mathrm{n}^{\circ}$ 18), en Torre (Amares, Fig. 5, no 21), en Areias de Vilar (Barcelos, Fig. 5, no 69), en Gamil (Barcelos, Fig. 5, no 73), en Varzea (Barcelos, Fig. 5, no 73), en el Monasterio de Banho (Vila Cova, Barcelos, Fig. 5, n⿳ 89), en Vale (Adaufe, Fig. 5, no 99), en Arentim (Braga, Fig. 5 ,
} 
Guimarães $^{184}$, del bajo valle del Limia ${ }^{185}$ y a lo largo del curso medio y, sobre todo, final del Duero ${ }^{186}$. En estas zonas, observamos el mismo fenómeno que acabamos de señalar. Así, por ejemplo, las transformaciones efectuadas en el edificio de San Fructuso de Montelios ${ }^{187}$ (Braga, Fig. 5 y $6, n^{\circ} 131$ ), típicas del mozárabe, van más en el sentido de 'ruptura' con un tipo de organización religiosa que en el de la idea de una nueva construcción de un edificio en 'ruinas'188 en un lugar 'despoblado'189. Respecto a esta 'ruina' de los antiguos edificios de culto, de su estado de abandono y de la nueva construcción de iglesias ${ }^{190}$, cada vez con mayor frecuencia la arqueología (a través del estudio de los vestigios y de los edificios de culto) nos indica que es más adecuado hablar de 'restauraciones' y de 'transforma-

$n^{0}$ 102), en Esporões (Braga, Fig. 5, $n^{0}$ 114), en São Paio de Merelim (Braga, Fig. 5, $n^{0} 121$ ), en Residencia Velha (Palmeira, Fig. 5 , n ${ }^{\circ}$ 128), en São Fructuoso de Montelios (Real, Braga, Fig. 5, n ${ }^{\circ} 131$ ), en Sobrebospa (Braga, Fig. 5, n 137), en Tenões (Braga, Fig. 5 , $n^{\circ} 138$ ), en São Martim de Dume (Braga, Fig. 5, n ${ }^{\circ} 141$ ), en Santa Leocadia de Briteiros (Guimarães, Fig. $5, n^{\circ} 265$ ), en Corvite (Longos, Guimarães, Fig. 5, $n^{0} 303$ ), en Moure (Vila Verde, Fig. 5 , $\left.n^{0} 724\right)$.

${ }^{184}$ Como, por ejemplo, en el Convento de Refojos (Cabeceiras de Basto, Fig. 5, $\mathrm{n}^{\circ}$ 153), en Antime (Fafe, Fig. 5, ${ }^{\circ}$ 246), en Castelões (Guimarães, Fig. 5, $n^{\circ}$ 269), en Santa Marina da Costa (Guimarães, Fig. 5, no 272), en Lordelo (Guimarães, Fig. 5, ${ }^{\circ}$ 280), en Pinheiro (Guimarães, Fig. 5, n ${ }^{\circ}$ 287), en São Torcato (Guimarães, Fig. 5, n' 293), en Paço (Lordelo, Guimarães, Fig. 5, $n^{0}$ 304), en São Salvador de Souto (Guimarães, Fig. 5, $n^{\circ}$ 305), en Santa Marina de Souto (Guimarães, Fig. 5, $n^{\circ} 306$ ), en Garfe (Povoa de Lanhoso, Fig. 5, $n^{\circ} 536$ ), en Paredes (São Cosme de Vale, Vila Nova de Famalicão, Fig. 5, nº 691).

${ }^{185}$ Como, por ejemplo, en Azére (Arcos de Valdevez, Fig. 5, $n^{\circ} 26$ ), en Mondim (Panque, Barcelos, Fig. 5, n ${ }^{\circ} 80$ ), en Quintães (Barcelos, Fig. 5, $\mathrm{n}^{\circ} 81$ ), en Vitorino dos Piães (Ponte de Lima, Fig. 5, $\mathrm{n}^{\circ}$ 517), en Beiral do Lima (Ponte de Lima, Fig. 5, $\mathrm{n}^{\circ}$ 519), en Amonde (Viana do Castelo, Fig. 5, $\mathrm{n}^{\circ}$ 627), en Castelo de Neiva (V. do Castelo, Fig. $5, \mathrm{n}^{\circ}$ 635), en Santa Leocadia de Geraz do Lima (V. do Castelo, Fig. 5, n ${ }^{\circ}$ 638), en São Romão de Neiva (V.do Castelo, Fig. 5, no 644), en el Monasterio de Vila Mou (V.do Castelo, Fig. 5, no 655), en Duas Igrejas (Vila Verde, Fig. 5, $n^{0} 722$ ).

${ }^{186}$ Como, por ejemplo, en Santa Cruz do Douro (Baião, Fig. 5, $\left.\mathrm{n}^{\circ} 44\right)$, en Moreira da Maia (Moreira, Maia, Fig. 5, no 330), en Abragão (Penafiel, Fig. 5, $\mathrm{n}^{\circ}$ 461), en Aldoar (Porto, Fig. $5, n^{0} 527$ ), en Cedo-feita (Porto, Fig. 5, $n^{0}$ 528), en Foz do Douro (Porto, Fig. 5, $n^{\circ} 529$ ) en Miragaia (Porto, Fig. $5, \mathrm{n}^{\circ}$ 530), en Provesende (Sabrosa, Vila Real, Fig. 5, $\mathrm{n}^{\circ}$ 554).

${ }^{187} \mathrm{H}$. SCHLUNK-T. HAUSCHILD, Die Denkmäler der frühchristlichen und westgotischen Zeit (Hispania Antiqua, II), Mainz, 1978; M. BARROCA, Contribução para o Estudo dos Testemunhos Pre-românicos de Entre-Douro-e-Minho. I. Ajimezes, Gelosias e Modilhões de Rolos, "Actas do Congreso Internacional do IX Centenario da Dedicação da Sé de Braga", I, Braga, 1990, pp. 101-145.

${ }^{188}$ C. Ferreira De Almeida, Arte da Alta Idade Media, op. cit., pp. 113-129.

${ }^{189}$ C. SÁNCHEZ Albornoz, Despoblación y Repoblación, op. cit.

${ }^{190}$ Ibidem. 
ciones $^{\prime 191}$ de antiguos edificios ya existentes desde al menos el siglo $\mathrm{VI}^{192}$.

En lo que concierne a la topografía funeraria, la repartición de sarcófagos (Fig. 14), continua, en cierta forma, un tipo de topografía funeraria que tiene también su origen en el s. VI. Se trata de las inhumaciones de las élites laicas o eclesiásticas y, lógicamente, su repartición va a corresponderse con las zonas situadas alrededor de los antiguos polos de organización y estructuración del territorio: el obispado de Orense ${ }^{193}$, del

\footnotetext{
${ }^{191}$ Como las observadas en las excavaciones arqueológicas de la iglesia de São Martin de Dumio (Fig. 5, $\mathrm{n}^{\circ} 141$ ), que han permitido ver el prolongamiento del ábside de la iglesia del siglo VI hacia finales del S. IX-X en una secuencia estratigráfica ininterrumpida): L. FONTES, Salvamento arqueologico de Dume- 1987. Primeiros resultados, "Cadernos de Arqueologia", 4 (1987), pp. 111-148; IDEM, Excavações arqueologicas de Dume São Martinho), resultados preliminares, "Trabalhos de Antropologia e Etnologia", (XXVII Actas do Coloquio de Arqueologia do Noroeste Peninsular, II), 1988, pp. 243-250; IDEM, Excavações arqueologicas na antiga igreja de Dume. Noticia preliminar da campanha de 1989, "IX Centenario", op. cit., pp. 147-169; Idem, Salvamento Arqueologico de Dume Braga). Resultados das Campanhas de 1989-90 e 1991-92, "Cadernos de Arqueologia", Serie II, 8/9, 1991-92, pp. 199-230. También en las excavaciones del Convento da Costa Guimarães, Fig. 5, $\mathrm{n}^{\mathbf{0}}$ 272), se hallaron las fundaciones de un edificio de culto anterior al que se construye en el siglo X: M. REAL, Convento da Costa (Guimarães). Historia y Arqueologia, Guimarães, 1980; IDEM, O Convento da Costa Guimarães). Noticia interpretação de alguns elementos arquitectonicos recentemente aparecidos, "Congresso Histórico de Guimarães e a sua colegiada", IV, 1981, pp. 461-475

${ }^{192} \mathrm{~A}$. de Jesus da Costa, para la región portuguesa de Entre-Douro-e-Minho, señala la existencia de vestigios arqueológicos de culto cuya cronología precede a la de su 'primera' mención en los textos: A. de Jesús Da CosTA, O Bispo D. Pedro, op. cit.; IDEM, Povoamento e colonização, op. cit.; IDEM, A comarca eclesiastica de Valença do Minho, op. cit. Para este mismo espacio: M. BARROCA, Contribução para o Estudo das Testemunhas pre-românicas, op. cit.; M. REAL, Inéditos de Arqueologia Medieval Portuense , "Arqueologia", 10 (1984), pp. 3043. Para la parte interior (provincia de Ourense): J.C. RIVAS FERNÁNDEZ, Algunas consideraciones sobre el pre-románico gallego y sus arcos de herradura geminados, "Boletín Auriense", I, (1971), pp. 61-125: IDEM, Un interesante vestigio de la iconografía visigótica procedente de la iglesia pre-románica de San Martiño de Pazo , "Boletín Auriense", VI (1976), pp. 169-182; IDEM, Vestigios pre-románicos de algunos olvidados monasterios orensanos, "Boletín Auriense" XI (1981), pp. 49-100

${ }^{193}$ Como, por ejemplo, en Sua-Torre de Ambía (Santa Eufemia de Ambía, Fig. 14, no 63), en San Pedro de Rocas (Esgos, Fig. 14, $n^{\circ}$ 236), en La Mezquita (La Merca, Fig. 14, $n^{\circ} 308$ ), en Asadur (Maceda, Fig. 14, n ${ }^{\circ} 324$ ), en San Vicente da Carballeira (Nogueira de Ramuín, Fig. 14, $n^{\circ} 420$ ), en Lamela (Pereiro de Aguiar, Fig. 14, $n^{\circ} 487$ ), en Moreiras (P. de Aguiar, Fig. 14, $\mathrm{n}^{\circ} 489$ ), en Torán (Taboadela, Fig. 14, $\mathrm{n}^{\circ} 577$ ).
} 
monasterio de Celanova ${ }^{194}$, del obispado de Braga ${ }^{195}$, del monasteriofortaleza de Guimarães ${ }^{196}$, de pequeños monasterios que van a surgir entre las desembocaduras del Limia y del Câvado ${ }^{197}$, del obispado de Oporto y de monasterios como el de Leça do Bailio y el de Vairão ${ }^{198}$, de la civitas Anegia (en Eja-entre-os-Rios) ${ }^{199}$, alrededor del eje Chaves ${ }^{200}$-Veríncastrum Baroncelli (Monterrei) ${ }^{201}$ y de Laroá202. Es en lugares importan-

${ }^{194}$ Como, por ejemplo, en Portoquintela (Baños de Bande, Fig. 14, $\mathrm{n}^{\mathrm{O}}$ 55), en Rubiás (Bande, Fig. 14, $n^{\circ}$ 57), en São Mamede de Lindoso (Ponte da Barca, Fig. 14, no 499), en la capilla de la Ascensión (San Andrés de Gontán, Verea, Fig. 14, nº 610).

${ }^{195}$ Como, por ejemplo, en Paredes Secas (Amares, Fig. 14, $n^{\circ} 20$ ), en Santa Leocadia de Briteiros (Guimarães, Fig. 14, $\mathrm{n}^{\circ}$ 265), en São Martinho de Sande (San Clemente de Sande, Guimarães, Fig. 14, $n^{\circ}$ 292), en Serzedelo (Guimarães, Fig. 14, $n^{\circ} 295$ ), en Balança (Terras de Bouro, Braga, Fig. 14, $\mathrm{n}^{\circ}$ 578).

${ }^{196}$ Como, por ejemplo, en São Torcato (Guimarães, Fig. 14, no 293), en São Estevão de Urgezes (Guimarães, Fig. 14, $n^{\circ}$ 301), en Quinta do Passal (São Martinho de Campos, Santo Tirso, Fig. 14, $n^{\circ}$ 564), en São Pedro de Roriz (Santo Tirso, Fig. 14, $n^{\circ}$ 568), en Abade de Vermoin (T. de Bouro, Braga, Fig. 14, $\mathrm{n}^{\circ}$ 578)

${ }^{197}$ Como, por ejemplo, alrededor del monasterio de Banho (Vila Cova, Barcelos): en Barcelos (Fig. 14, $\mathrm{n}^{\mathrm{0}} 71$ ), en Santa Marinha de Galegos (Barcelos, Fig. 14, $\mathrm{n}^{\mathrm{0}}$ 72), en Gamil (Barcelos, Fig. 14, $n^{\circ} 73$ ), en Igreja Nova (Barcelos, Fig. 14, $n^{\circ} 75$ ), en Lama (Barcelos, Fig. 14, $\mathrm{n}^{\circ}$ 76), en Manhente (Barcelos, Fig. 14, $\mathrm{n}^{\circ}$ 77), en Mondim (Panque, Barcelos, Fig. 14, n ${ }^{\circ} 80$ ), en Santa Eugenia de Riocovo (Barcelos, Fig. 14, n⿳ 82), en São Bento de Varzea (Barcelos, Fig. 14, $n^{\circ} 88$ ), en el Monasterio de Banho (Vila Cova, Barcelos, Fig. 14, $n^{\circ} 89$ ), en Abade de Neiva (Barcelos, Fig. 14, $\mathrm{n}^{\circ}$ 90), en Aldreu (Barcelos, Fig. 14, $\mathrm{n}^{\circ}$ 68). Alrededor del monasterio de Vila Mou (Viana do Castelo): en Calvelo (P. de Lima, Fig. 14, $n^{\circ}$ 504), en São Julião de Freixo (P. de Lima, Fig. 14, $\mathrm{n}^{\circ}$ 508), en Friastelas (P. de Lima, Fig. 14, $\mathrm{n}^{0}$ 509), en Santo Estevão da Facha (P. de Lima, Fig. 14, n ${ }^{\circ}$ 507), en Vitorino dos Piães (P.de Lima, Fig. 14, $\mathrm{n}^{\circ}$ 517), en Cardielos (V. do Castelo, Fig. 14, $\mathrm{n}^{\circ}$ 631), en Castelo do Neiva (V.do Castelo, Fig. 14, $n^{\circ}$ 646), en Santa Leocadia de Geraz do Lima (V. do Castelo, Fig. 14 $n^{\circ}$ 638), en Santa Marina de Geraz do Lima (V. do Castelo, Fig. 14, $n^{\circ}$ 639), en Nogueira (V. do Castelo, Fig. 14, $n^{\circ}$ 646), en Serreleis (V. do Castelo, Fig. 14, $n^{\circ} 651$ ).

${ }^{198}$ Como, por ejemplo, en Aguas Santas (Maia, Fig. 14, n ${ }^{\circ}$ 326), en São Pedro de Avioso (Maia, Fig. 14, $\mathrm{n}^{\mathrm{O}}$ 328), en Moreira da Maia (Maia, Fig. 14, $\mathrm{n}^{\mathbf{0}} 330$ ), en São Martim de Guifões (Matosinhos, Fig. 14, $n^{0}$ 365), en Lavra (Matosinhos, Fig. 14, $n^{0}$ 366), en el monasterio de Leça do Bailio (Matosinhos, Fig. 14, $\mathrm{n}^{\circ}$ 368), en la capilla de São Bras (São Pedro-Fins de Canidelo, Fig. 14, $\mathrm{n}^{\circ}$ 661), en el monasterio de Vairão (Vila do Conde, Fig. 14, $\mathrm{n}^{\circ}$ 667)

${ }^{199}$ Como, por ejemplo, en Folhada (M. de Canaveses, Fig. 14, $\mathrm{n}^{\circ} 336$ ), en Penha Longa (M. de Canaveses, Fig. 14, no 344), en Tuias (M. de Canaveses, Fig. 14, no 358), en Quinta do Passal (Varzea do Douro, M. de Canaveses, Fig. 14, $n^{\circ} 359$ ), en Portela (Vila Boa de Quires, M. de Canaveses, Fig. 14, no 362), en Messão Frio (Fig. 14, n 377).

${ }^{200}$ Como, por ejemplo, en Chaves (Fig. 14, $\mathrm{n}^{\circ}$ 211), en São Caetano (Ervedo, Chaves, Fig. $14, n^{\circ} 213$ ), en São Pedro de Faiões (Chaves, Fig. 14, $n^{\circ} 214$ ), en la capilla de São Martin (Mairos, Chaves, Fig. 14, no 215), en São Antonio de Monforte (Chaves, Fig. 14, no 216).

${ }^{201}$ Como, por ejemplo, en Servoi (Vilar de Servoi, Fig. 14, no 187), en Albarellos (Monterrei, Fig. 14, $n^{\circ} 408$ ), en Estevesiños (Monterrei, Fig. 14, $n^{\circ} 410$ ), en la iglesia de Santa Mariña de Gracia (Monterrei, Fig. 14, n⿳0 ${ }^{\circ} 414$ ), en Vilaza (Monterrei, Fig. 14, no 415), en Xironda (Cualedro, Fig. 14, $n^{0} 231$ ). 
tes desde el punto de vistade la organización política y religiosa, en donde van a residir y a instalarse las élites político-religiosas que llevarán a cabo este vasto proceso de 'reorganización' territorial. La topografía funeraria nos muestra también la relación con el proceso de instalación de las élites rurales que había sido iniciado a mediados del s. $\mathrm{VI}^{203}$.

Tanto la topografía religiosa (Figs. 5, 6 y 7) como la topografía funeraria (Fig. 14), subrayan el contraste entre el tipo de poblamiento y de organización existente durante el VIII y la mayor parte del IX (Figs. 4 y 13), y el que se va a instalar comoconsecuencia del vasto proceso de 'reorganización' territorial que se efectua entre el Miño y el Duero desde mediados del IX y durante todo el siglo X. Su objetivo: 'restaurar' la antigua red eclesiástica rural que había comenzado a estructurarse desde mediados del VI, con otros protagonistas (entre ellos los mozárabes y las nuevas élites) que van a 'reconstruir' y a 'transformar' antiguas iglesias y monasterios en los cuales el aspecto exterior reflejará perfectamente el contexto sociopolítico y religioso del momento, y que van a inhumarse como corresponde a las élites: en sepulturas privilegiadas tipo sarcófago, a veces con laudas de estola para 'retomar' una idea de la jerarquía que tiene, también, su orígen a mediados del siglo VI. Las excavaciones y las mejores dataciones de estos edificios y vestigios de culto, permiten cuestionar la idea de un paisaje de iglesias 'abandonadas' y en 'ruinas', que habrían encontrado las gentes que acompañaban al conde Vimara Perez o al conde Odoario en la segunda mitad del siglo IX. Al contrario, debemos de comenzar a hablar de 'transformaciones' de antiguas iglesias y de la 'restauración' de una red eclesiástica antigua $^{204}$.

\footnotetext{
${ }^{202}$ Como, por ejemplo, en Garabelos (Baltar, Fig. 14, $n^{\circ}$ 52), en Lucenza (Cualedro, Fig. $14, n^{\circ} 224$ ), en Lobaces (Trasmiras, Fig. 14, $n^{\circ} 600$ ), en San Pedro de Laroá (Xinzo de Limia, Fig. 14, ${ }^{\circ} 739$ ), en Seoane de Oleiros (Xinzo de Limia, Fig. 14, $n^{\circ} 744$ ).

${ }^{203}$ Prueba de ello es la 'recuperación' (puesto que tiene su orígen en el siglo VI) de la estola como símbolo, que va a estar presente sobre las cubiertas de ciertos sarcófagos, de la jerarquía y de esas élites eclesiásticas rurales. J. LÓPEZ QUIROGA-M. RODRÍGUEZ LOVELLE, Las estelas funerarias con la representació del 'orante' y de la 'estola': Un testimonio del conflicto ortodoxia-heterodoxia en el noroeste de la Península Ibérica durante la Antigüedad tardía (ss. V-VII), "Portugalia", en prensa. J. LóPEZ QuIROGA, Du Miño au Douro, op. cit., pp. 648-659.

${ }^{204}$ Como ya lo había demostrado P. David en lo referente a las advocaciones de las iglesias: P. DAVID, Etudes historiques, op. cit.
} 


\section{EPÍLOGO: \\ DE 'DESIERTOS', 'OASIS' Y 'FANTASMAS' EN LA ESPAÑA MEDIEVAL}

Podríamos decir que esta frase sintetiza, en un sentido metafórico, sinninguna duda, buena parte de la historia altomedieval a lo largo y ancho del 'valle delDuero historiográfico' ${ }^{205}$. En efecto, desde que Sánchez Albornoz considerara este espacio como un vasto 'desierto' con algunos 'oasis', como en todo desierto ${ }^{206}$, la historiografía posterior se ha dedicado a intentar disminuir la extensión del 'desierto' a través del incremento del numero de los 'oasis', cargando a sus espaldas con ciertos 'fantasmas' (los de Alfonso I, el de su hermano Fruela y, por supuesto, el de Sánchez Albornoz) que cada vez se han ido haciendo más pesados e incómodos. Ello es debido, en gran parte, a las 'armas' que los medievalistas han utilizado para 'combatir' las tesis albornocianas. Efectivamente, la utilización de la misma documentación empleada por Sánchez Albornoz, para rebatir sus argumentos, ha derivado en un discurso más contra los 'fantasmas' que contra el 'desierto' duriense. Visto que los 'oasis' eran menos numerosos de lo que se pensaba, sobre todo a partir de una docu-mentación que, por lo general, no remonta más allá del siglo $\mathrm{IX}^{207}$ y que las pruebas arqueológicas mencionadas, se limitaban a repetir sistemáticamente la 'prueba'de la existencia de un 'oasis' en el Castellar (Villajimena, Palencia) ${ }^{208}$, se ha decidido que lo más 'cómodo', como suelen decir en el país vecino, es 'tuer le père'. El problema es que Sánchez Albornoz, lamentablemente, ya está muerto y, por lo tanto, los 'fantasmas' son imposibles de eliminar si no se ataca directamente la 'fuente' de su 'espíritu atormentado'. La vía no es negar las, sin duda, sólidas bases de su teoría, ni el cuestionar la cientificidad de la misma, ni negar el 'desierto' (sin decir dónde están los 'oasis'), ni considerar ese tema 'superado' y 'rancio'... Sánchez Albornoz, no dudó en utilizar (otro problema es, si lo hizo acertadamento o no) todas las 'armas'

\footnotetext{
${ }^{205}$ Aquel que, como hemos visto, desborda ampliamente ambos márgenes del Duero, según el criterio de análisis de Sánchez Albornoz.

${ }^{206}$ C. SÁNChez Albornoz, Despoblación y Repoblación en el valle del Duero, op. cit.

${ }^{207}$ Aunque la situación que reflejan pueda, forzando los textos, remontarse a la segunda mitad del siglo VIII, y ello dependiendo de qué zona del valle del Duero hablemos. Por ejemplo, para el espacio del Miño al Duero, remontar más allá del IX a partir de la información de los textos, es muy arriesgado y, desde luego, aventurado.

${ }^{208}$ M.A. García Guinea-J. González Echegaray-B. Madariaga de la Campa, El Castellar, Villajimena (Palencia), (Excavaciones Arqueológicas en España, 22), 1963.
} 
a su alcanze cuando elaboró su teoría de la 'despoblación' y de la posterior 'repoblación' del valle del Duero: textos, toponimia, hagiotoponimia, arqueología... Además, no se limitó a construir una historia del poblamiento entre el s. VIII y el X, sino que lo hizo desde época romana, estableciendo una 'cesura' en el estudio del período del s. $\mathrm{V}$ al X, y una 'ruptura' radical en la evolución del poblamiento en el siglo VIII. Si algo ha cambiado desde la formulación de la tesis de Sánchez Albornoz no son las fuentes documentales, sino los ojos que analizan los mismos textos una y otra vez. Recurrir al discurso fácil y cómodo de considerar el período entre los siglos V y VII como 'muy lejano' al medievalista ${ }^{209}$, o esperar los resultados de la 'Arqueología Medieval' española, es un lujo que los medievalistas no nos podemos simplemente permitir. Si queremos avanzar, si queremos superar los fáciles clichés, si no queremos limitarnos al reduccionismo 'ruptura' o 'continuidad', si no queremos aislarnos, una vez más, de la investigación que se hace 'del otro lado de los Pirineos' (y no nos referimos exclusivamente al País vecino)... el medievalista está obligado a utilizar todas las fuentes disponibles. Si el medievalista que aborda este período y este tema claves en la Historia de la España cristiana medieval, no utiliza, como historiador, todas las fuentes...entonces, muy a su pesar, tendrá que terminar por recurrir a la 'brujería' para eliminar el 'fantasma' de Alfonso I, el de su hermano Fruela y el de Sánchez Albornoz, ya que de lo contrario éstos le serán indispensables para construir su discurso a partir de los textos...

\footnotetext{
${ }^{209}$ Fundamental, sin embargo, para comprender la alta Edad Media y, por lo tanto, para cualquier medievalista: "...infatti, non potremmo capire nulla dell' alto Medioevo se non considerassimo la connessioone diquesto con quanto lo precedette...", C. WICKHAM, L'Italia e l'alto Medioevo, "Archeologia Medievale", XV (1988), pp. 106-107 (pp. 105-124). Trabajos como el de E. Pastor constituyen la prueba de la necesidad cada vez más imperiosa de conocer directamente la situación anterior al siglo VIII si queremos comprender lo que sucede después (otra cuestión son las conclusiones de este trabajo para ese período, con las que no coincidimos plenamente ): E. PASTOR DÍAZ DE GARAYO, Castilla en el tránsito de la Antigüedad al Feudalismo, op. cit. Por el contrario, las conclusiones de M.Fernández Mier se aproximan bastante a lo observado al Norte del Miño (el espacio entre el Cantábrico y el Miño-Sil): $\mathrm{M}$. FERNÁNDEZ MIER, Transformaciones del poblamiento en la transición del mundo antiguo al medieval en la montaña asturiana (Península Ibérica), "Archeologia Medievale", XXIII (1996), pp. 101- 129; M. RodRíguEz LOVElle, Du Golfe Cantabrique au Miño: Histoire et Archéologie du peuplement entre l'Antiquité tardive et le Haut Moyen Âge, Universidad de Paris-Sorbonne, Universidad de Santiago de Compostela, Tesis doctoral inédita, París-Santiago, 1998.
} 


\section{RÉSUMÉ}

Dans ce travail nous proposons, à partir de la region de Galice et du Nord du Portugal (le nord-Ouest de la Péninsule Ibérique), et plus précisément entre les fleuves Miño et Douro, les résultats de notre recherche sur l'évolution du peplement rural durant le haut Moyen Âge (VIII $-\mathrm{X}^{\mathrm{e}}$ ss.).

D'une part, on étude les problématiques VIII et $\mathrm{IX}^{\mathrm{e}}$ siècles: d'abord, une petite historiographie, ensuite, nous proposons un modèle interprétatif fondé sur l'analyse de la region entre le Miño et le Douro. D'autre part, on aborde la période entre la fin du $\mathrm{IX}^{\mathrm{e}}$ et le $\mathrm{X}^{\mathrm{e}}$ siècles: nous constatons, d'un côté la 'naissance' des villae à partir des textes et en ce qui concerne notre région d'étude; et d'autre côté, la restauration d'un peuplement ancien, au même temps que la réorganisation de l'ancien réseau ecclésiastique rural. C'est-à-dire, un vaste processus de réaménagement territorial dirigé par la monarchie asturléonaise, très loin de l'image classique d'une Reconquista et d'un 'repeuplement' sur des terres vides de toute population.

\section{SUMMARY}

This article propose, from a concrete area (Galicia and North Portugal in the North West of the Iberian Peninsula) and exactly between Miño and Douro valleys, the results of our research about Early Medieval rural settlement (700-1000 A.D.).

For the period 700-880 A.D. (after a short historiographical summary) we propose an interpreting model from our area about rural settlement. Between 880-1000 A.D., we notice the 'birth' of the rural villae from documentary evidence; the restauration of the ancien rural settlement; and the reorganization of the ancien ecclesiastical organization. That means a great process of territorial reorganization ordered by the asturian dinasty, but not a 'Reconquest' process about a no man's land in Douro valley. 

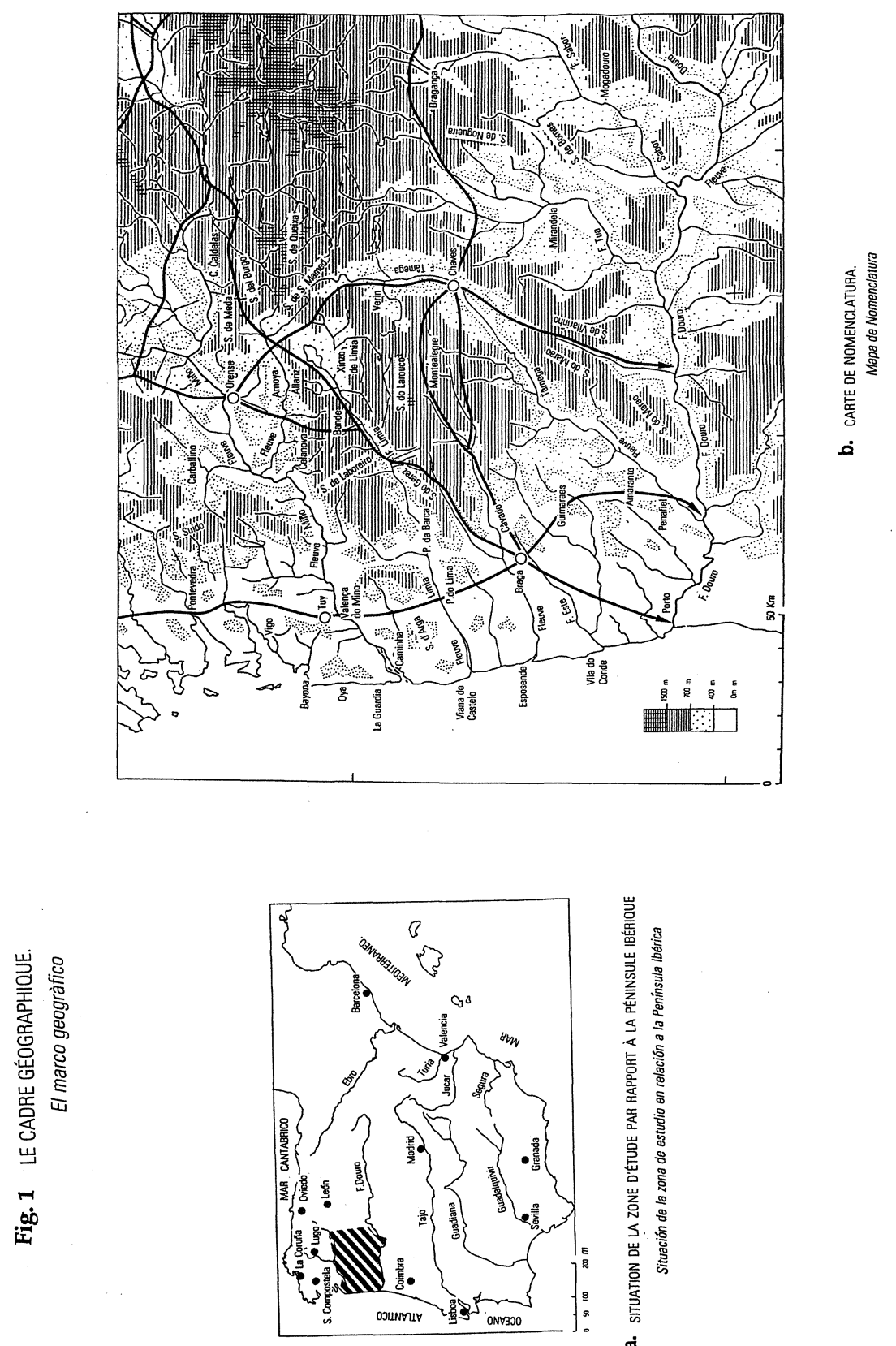

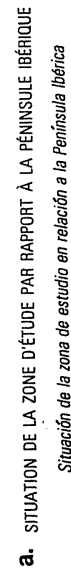




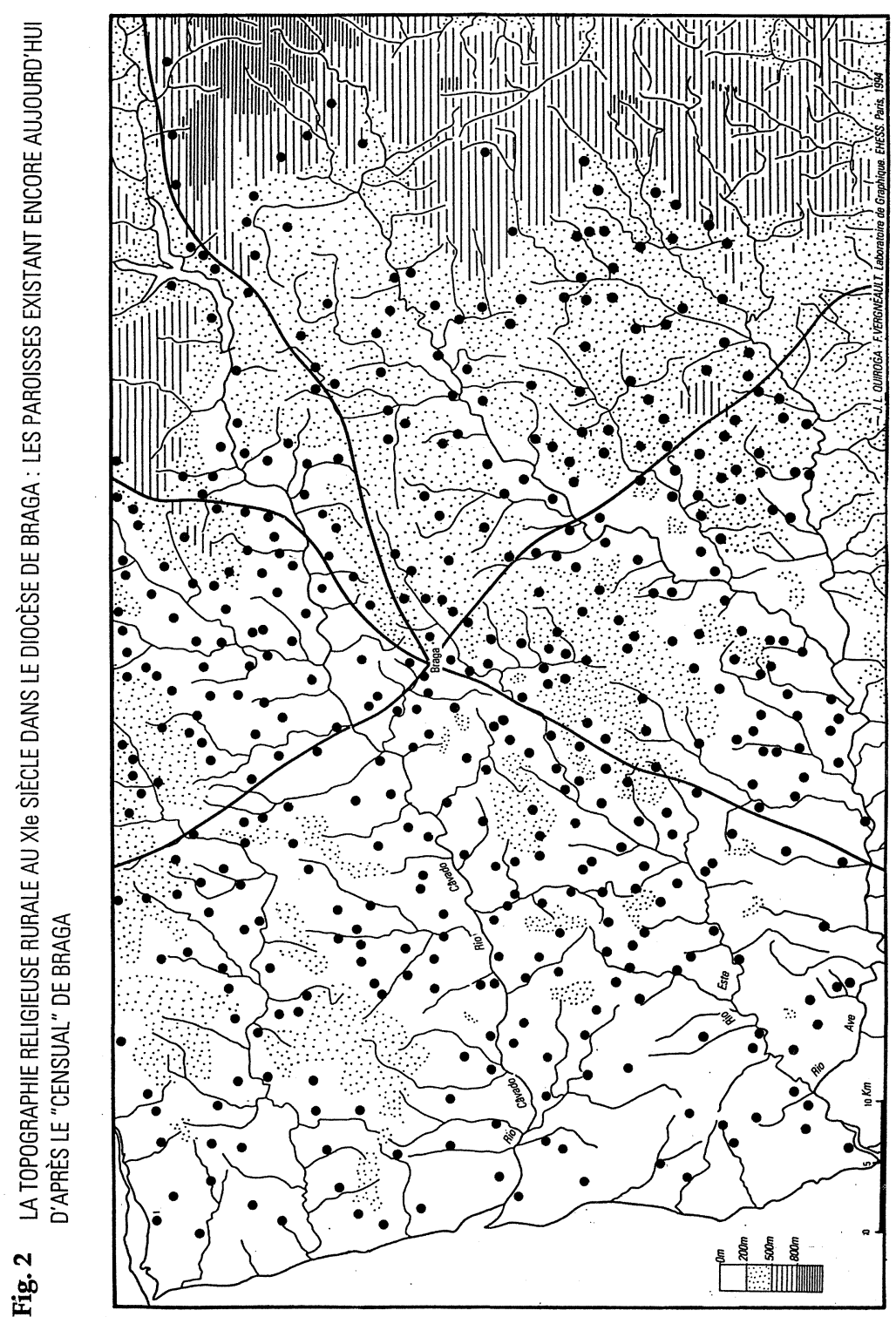

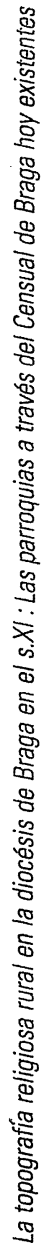




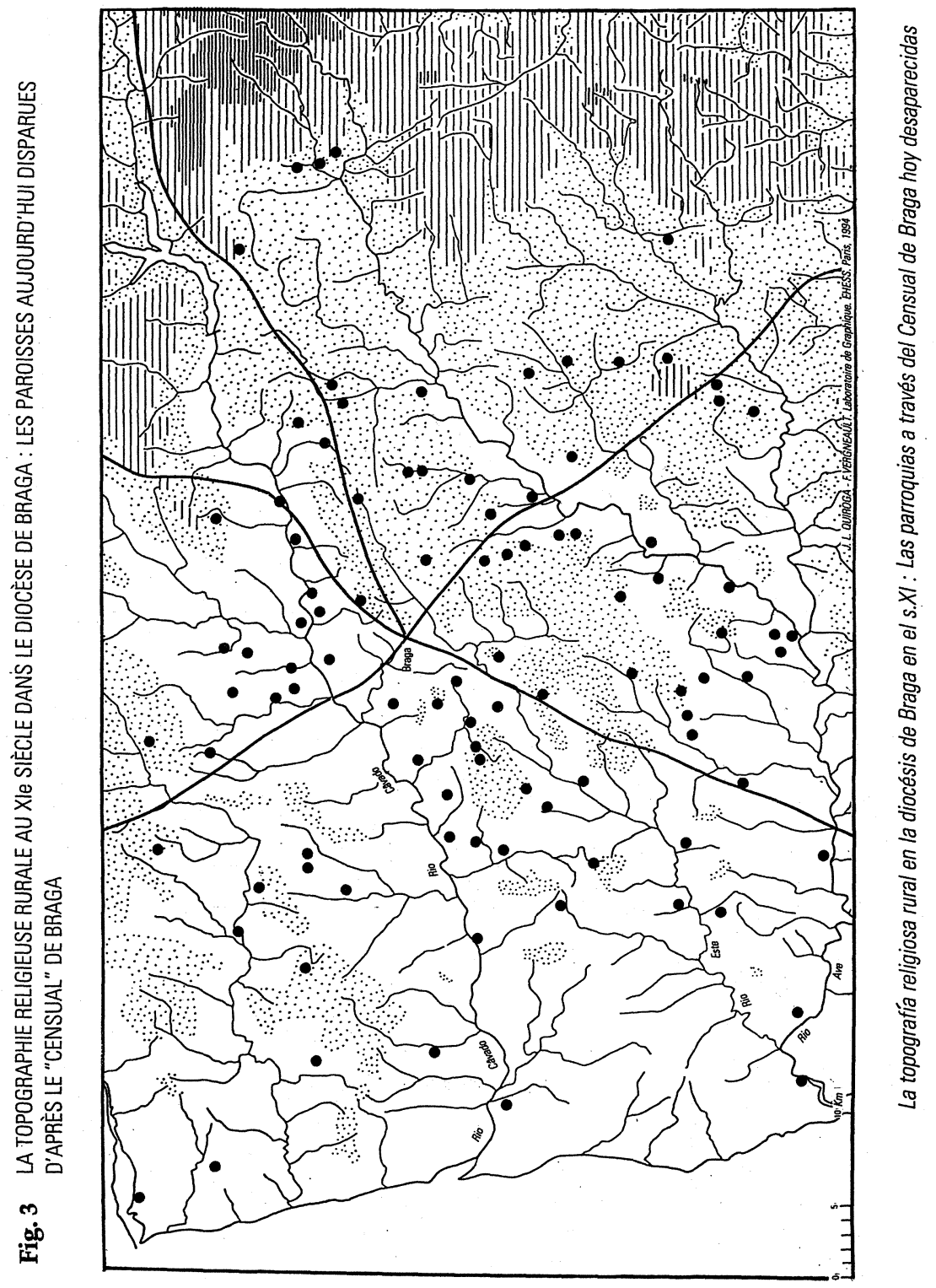



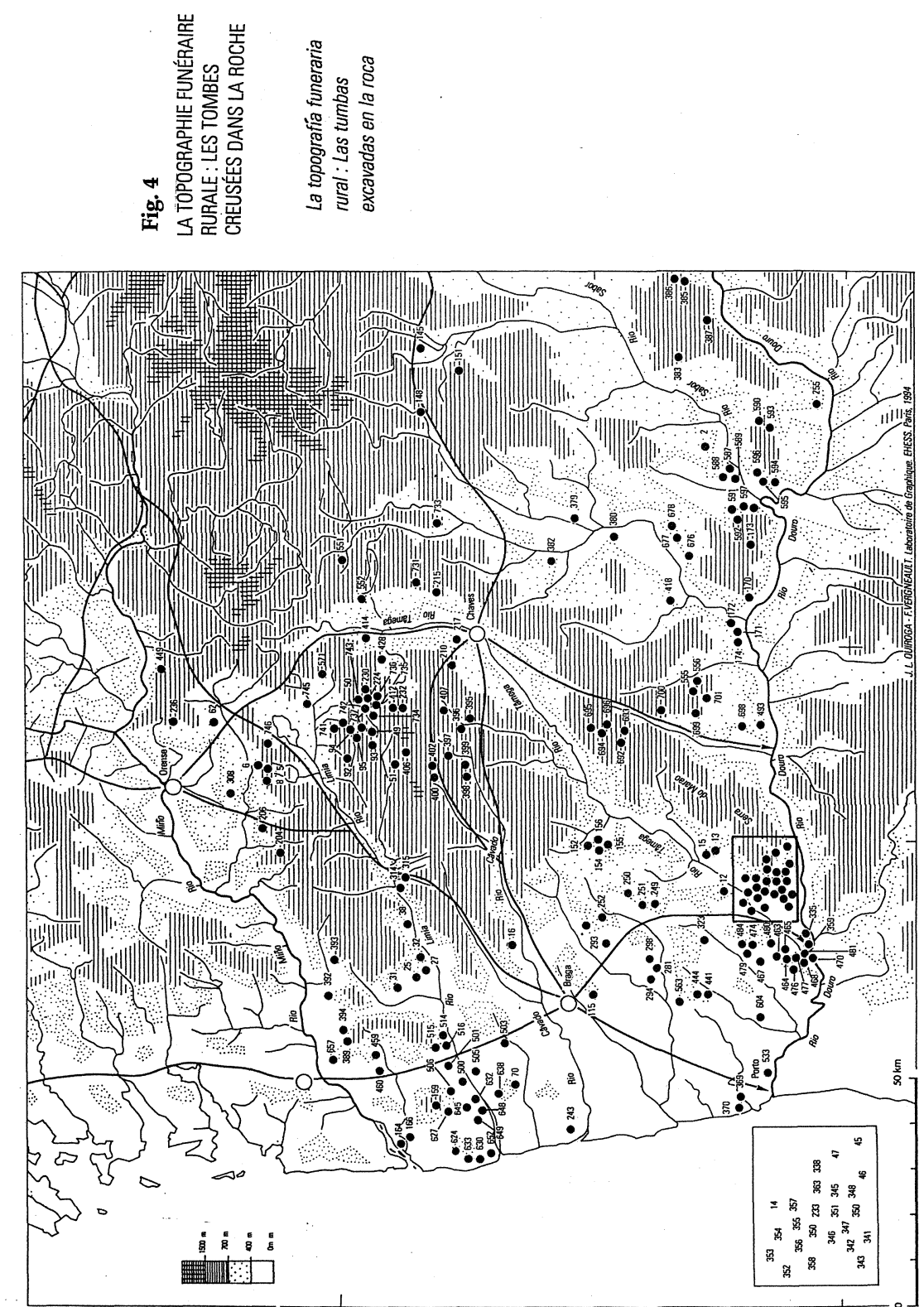

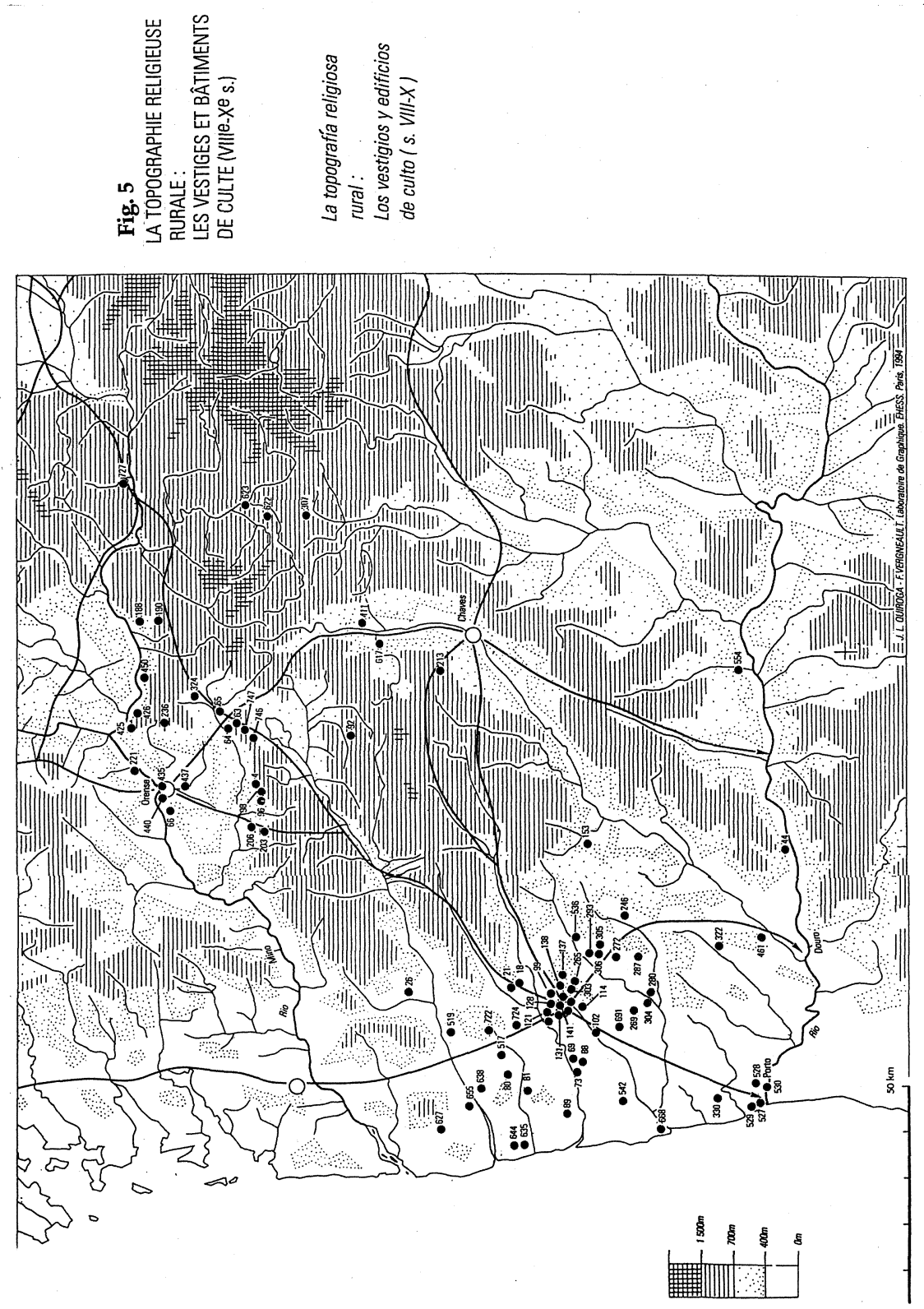


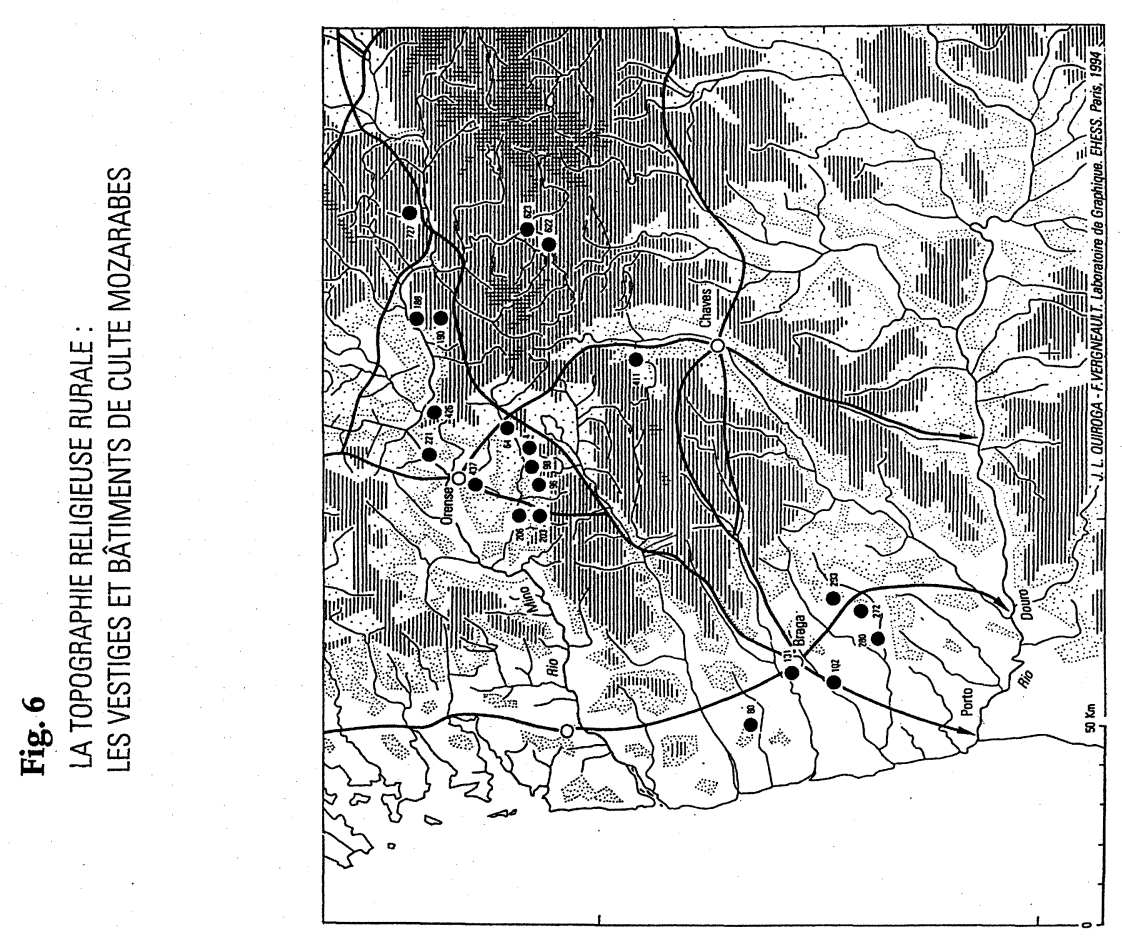



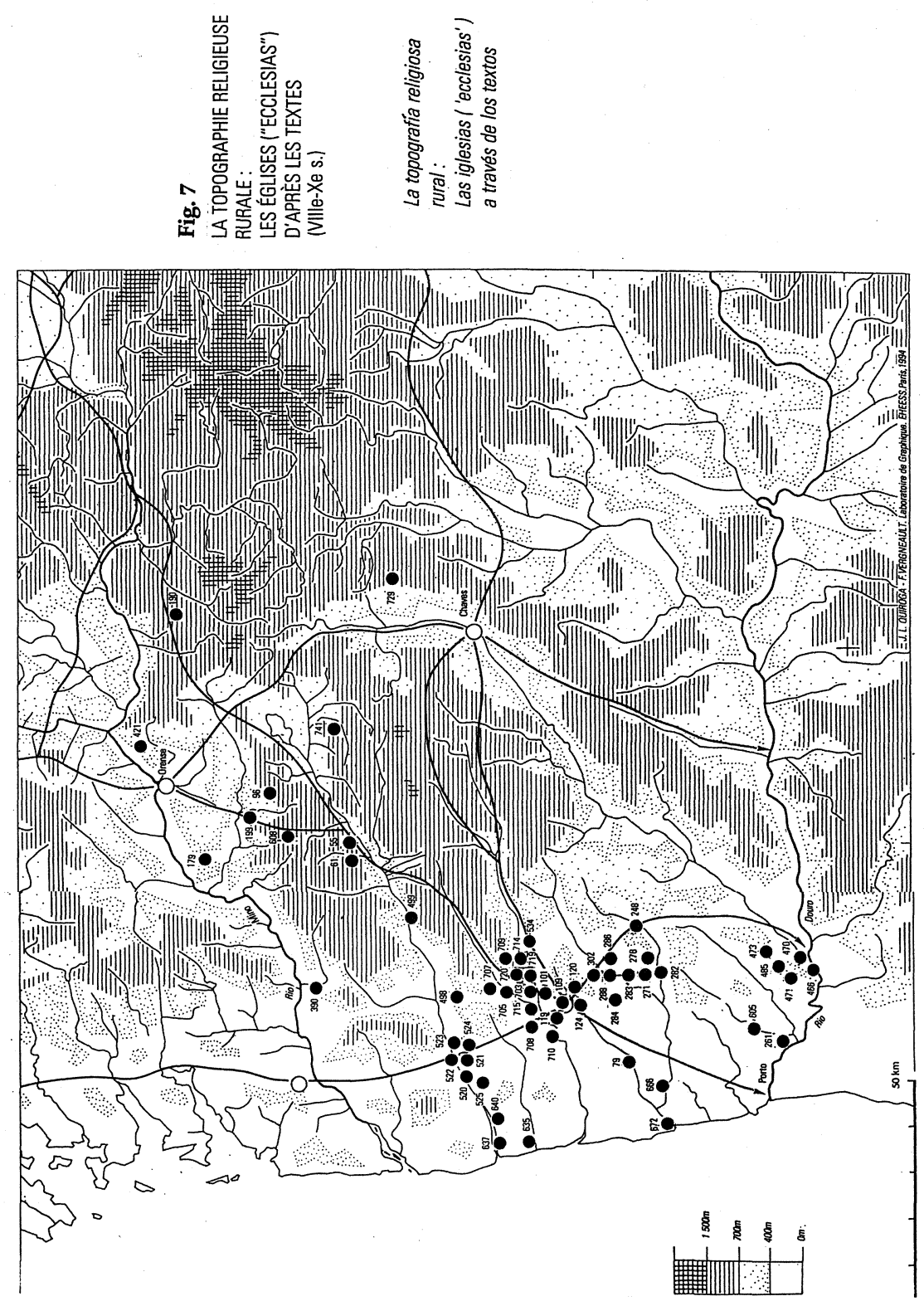

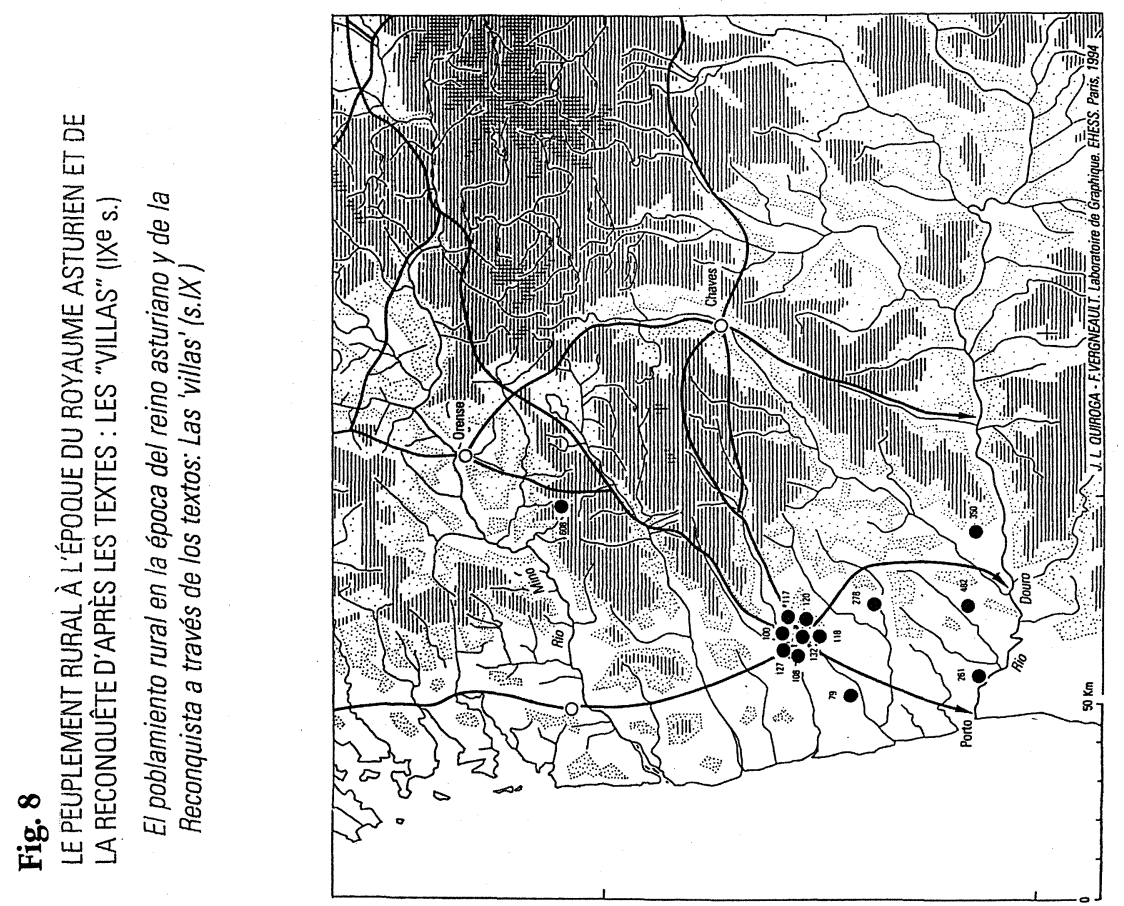


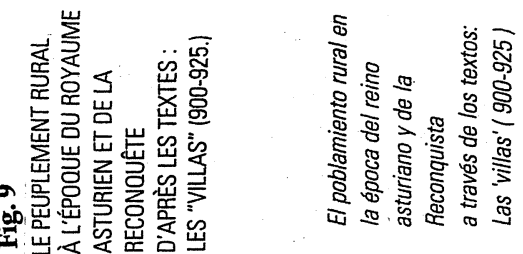

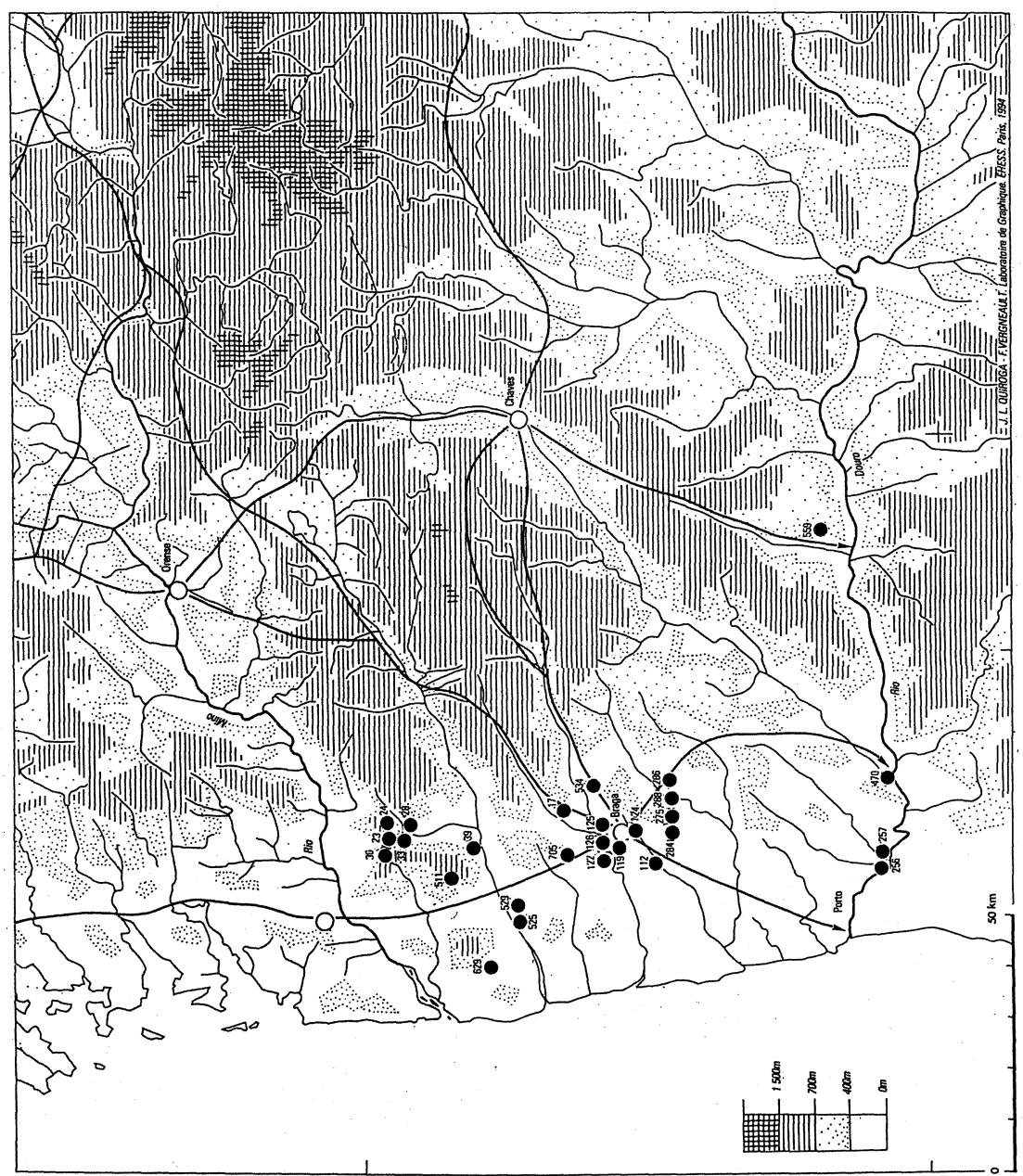




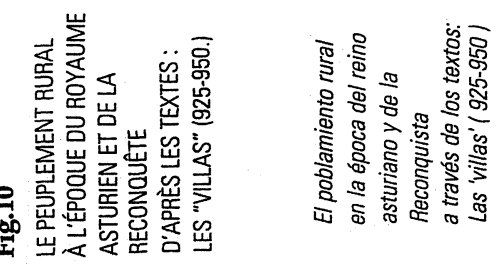

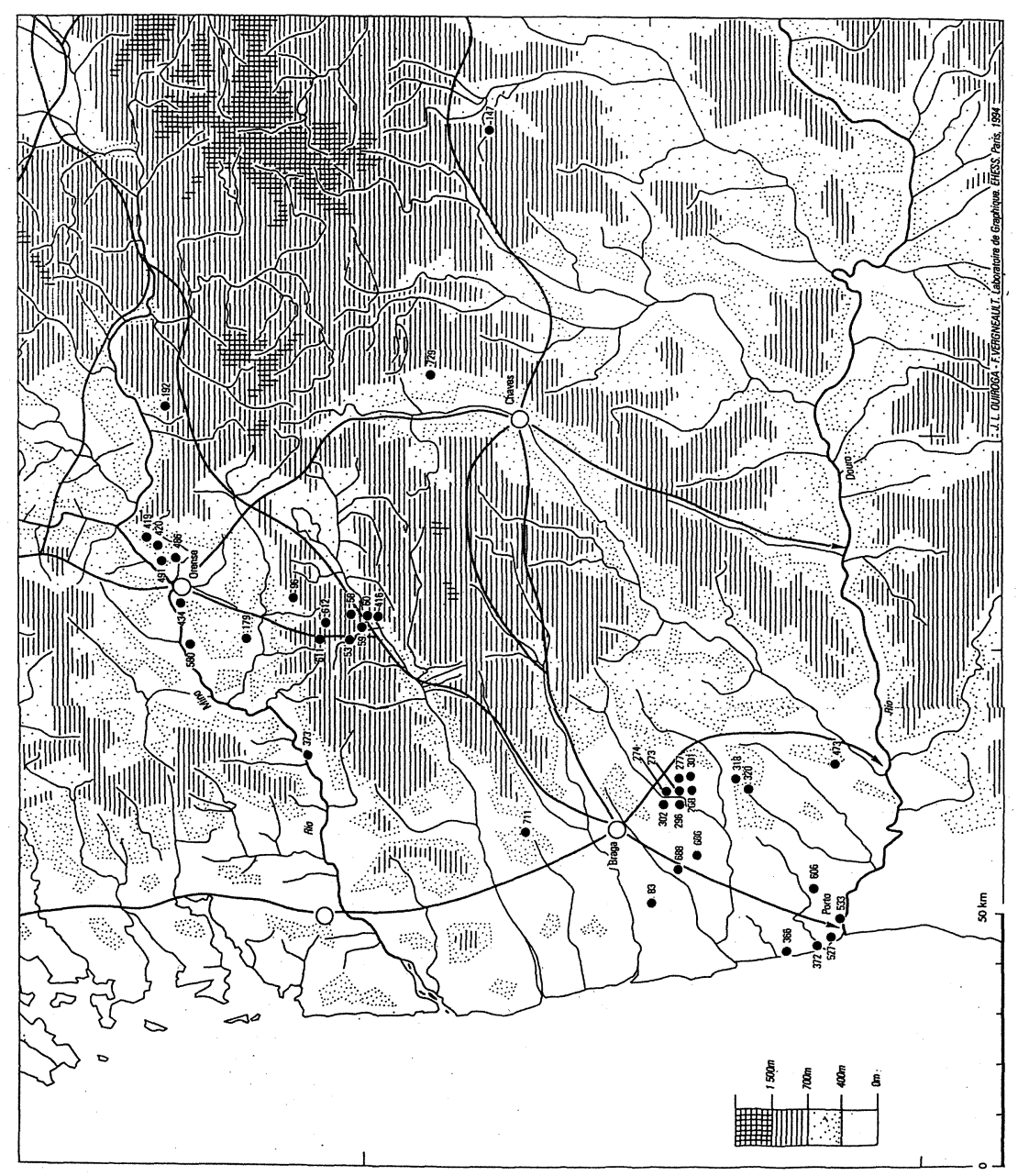



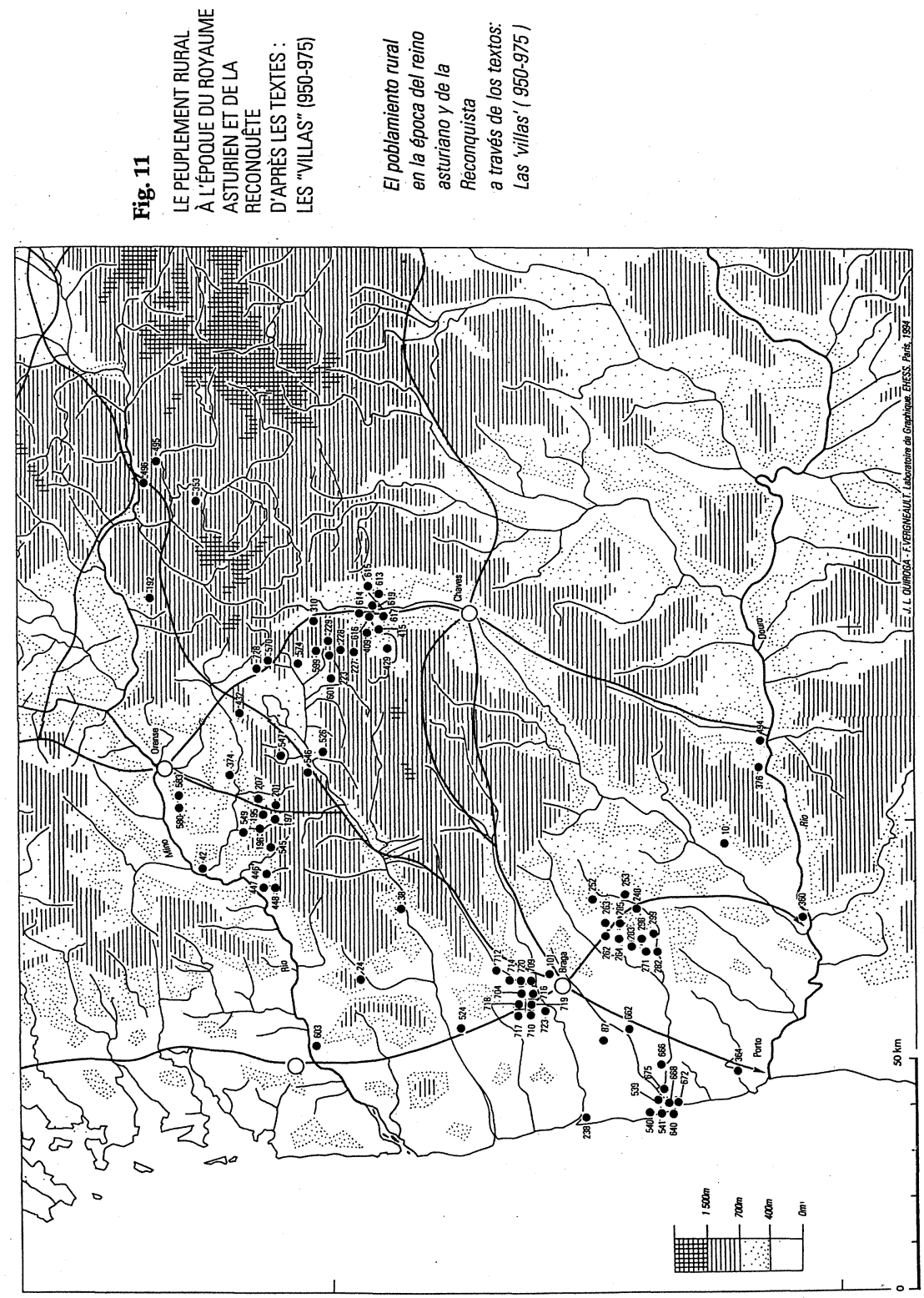


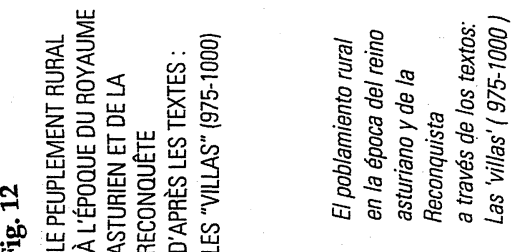

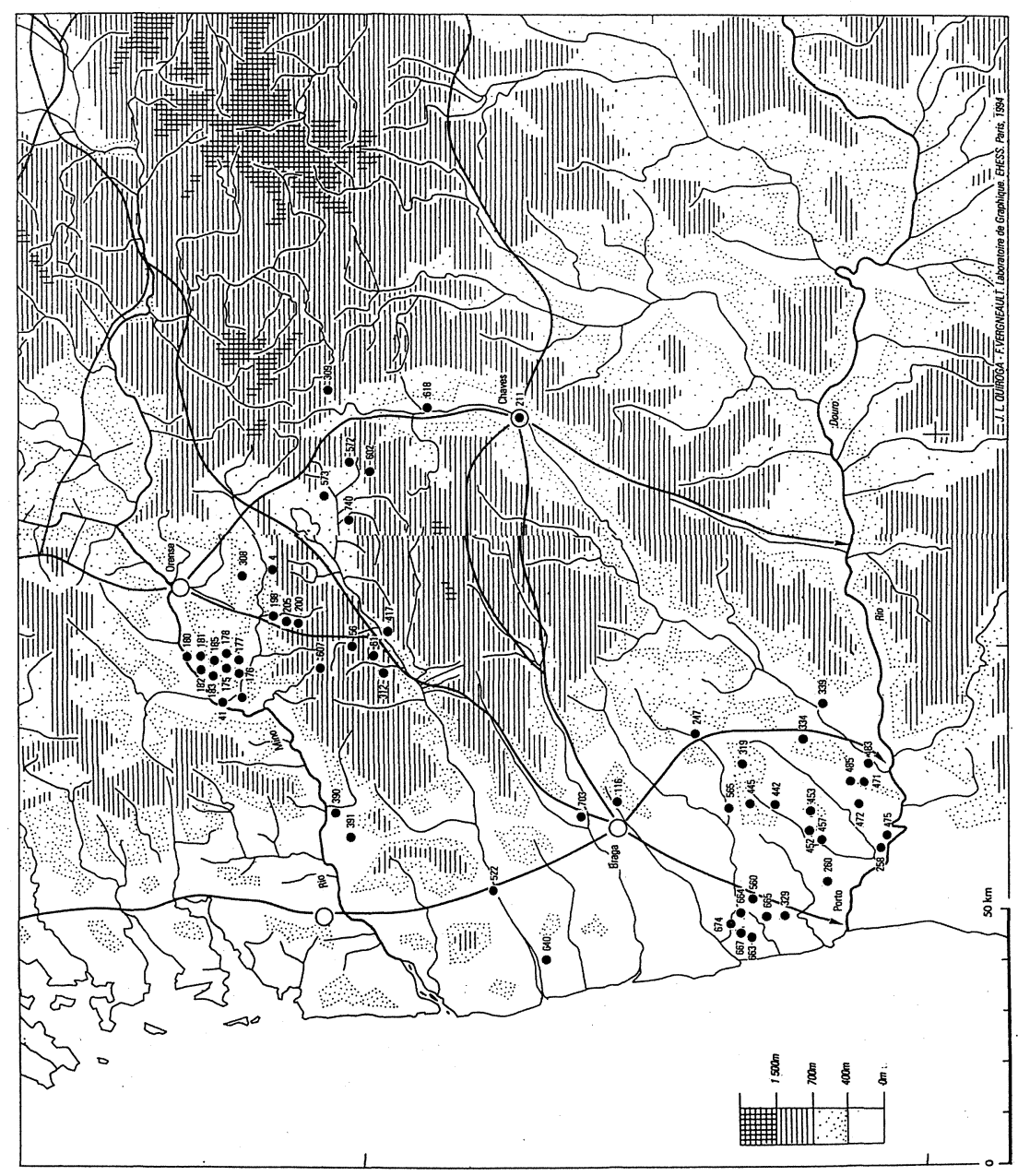




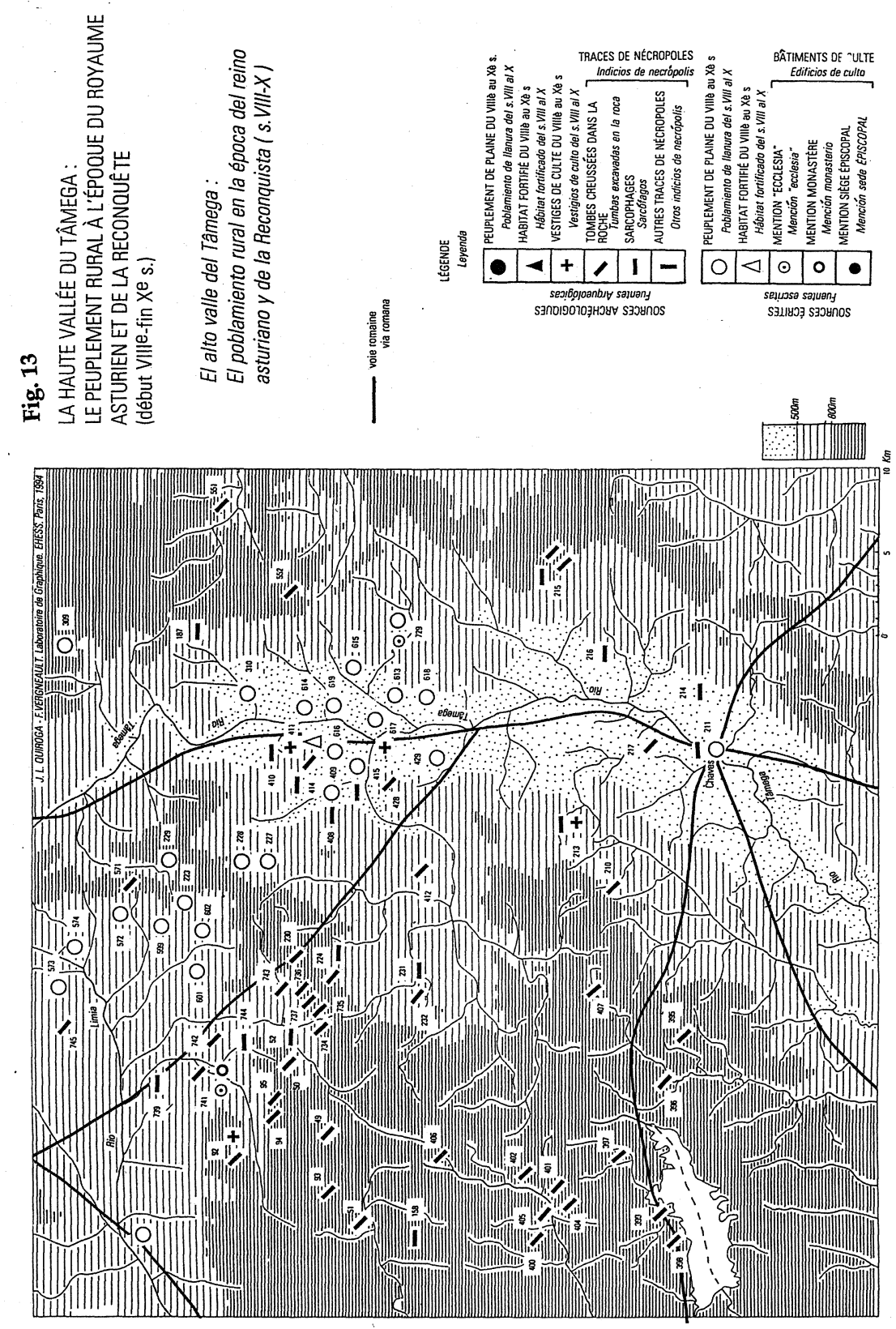




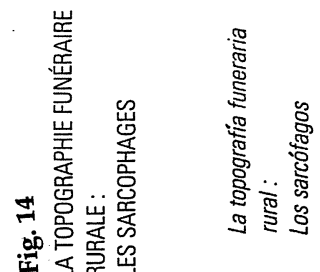

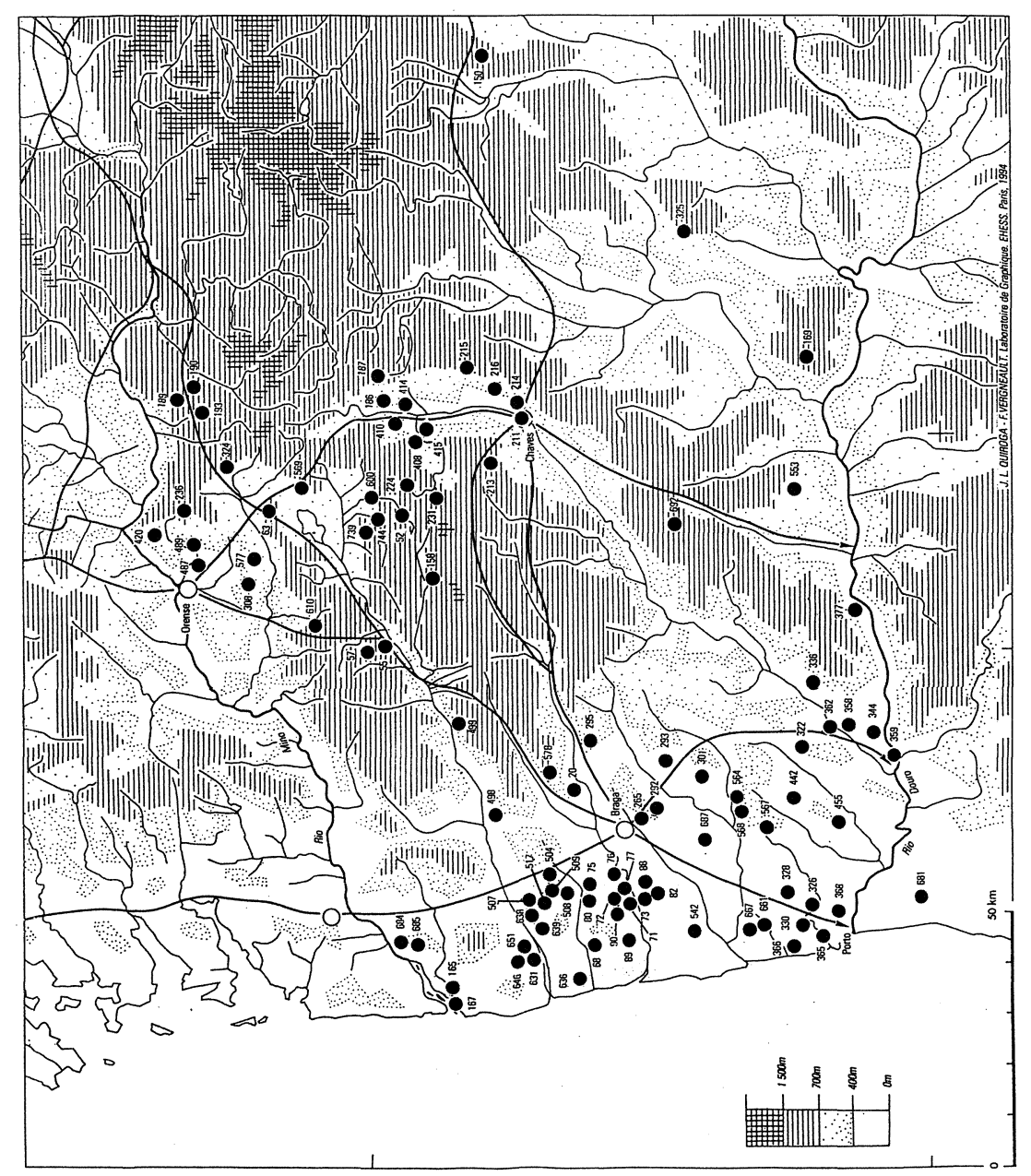

